if 413

E13 opy 1

of the

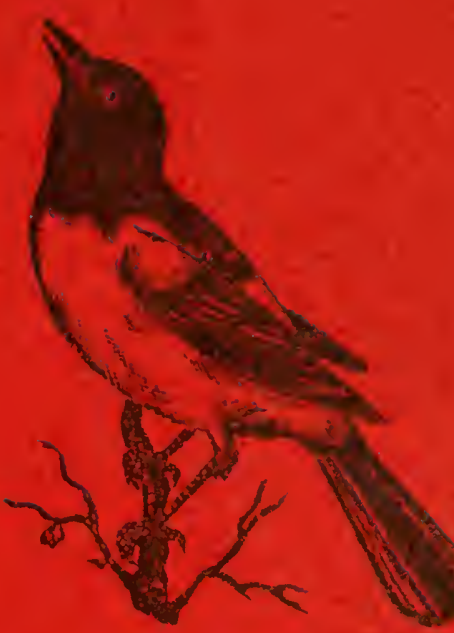

Household

EARI

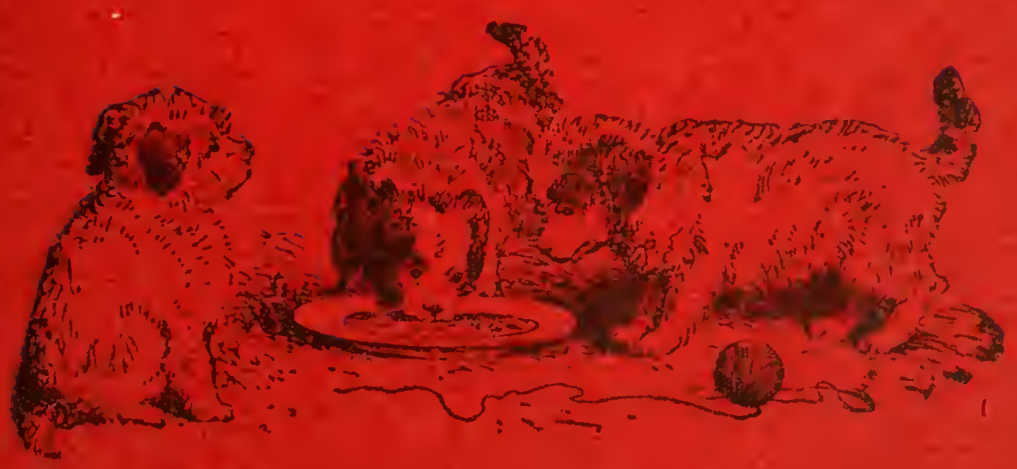





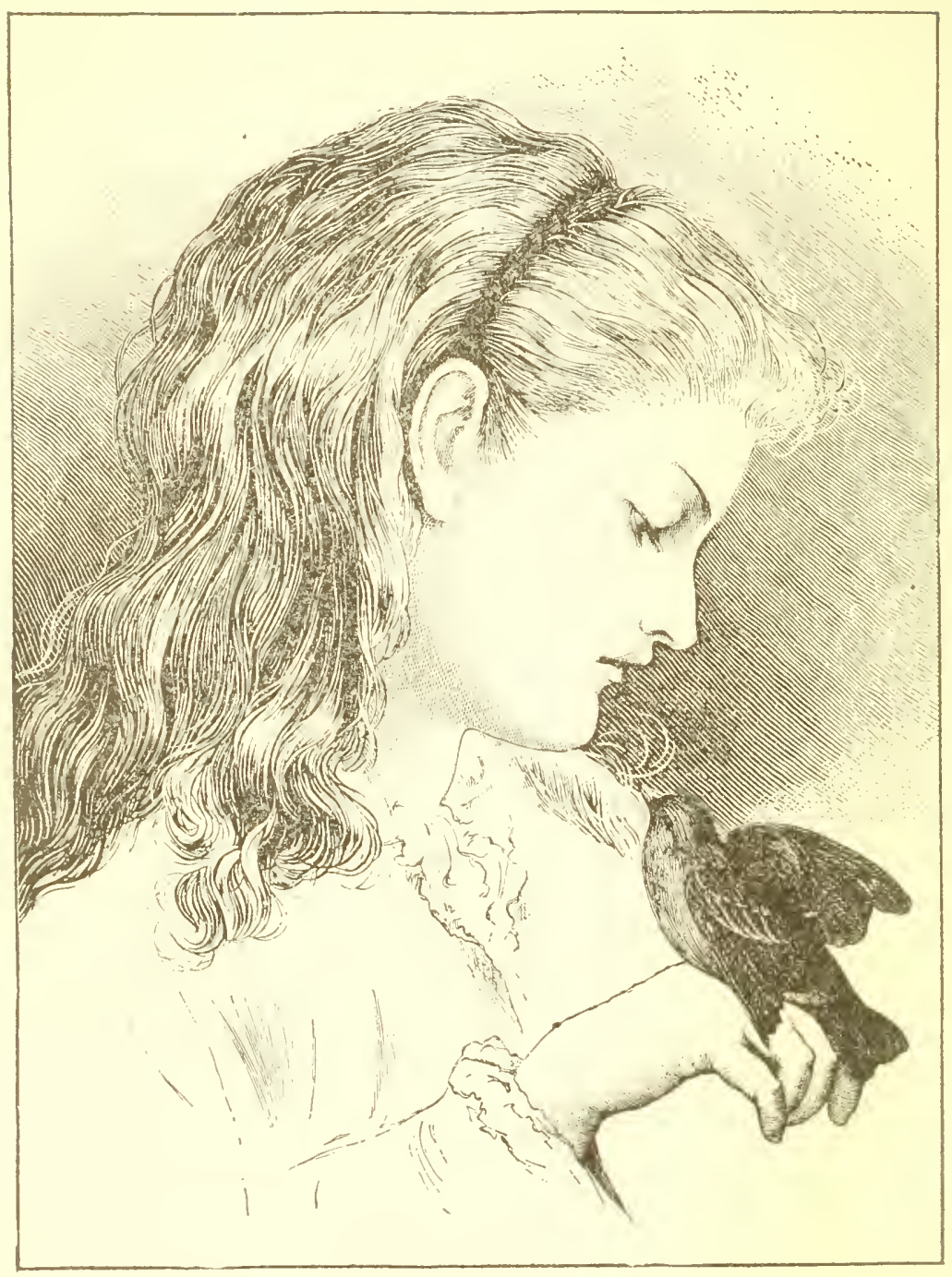




\section{PETS OF THE HOUSEHOLD}

THEIR

\section{CARE IN HEALTH AND DISEASE}

BY

THOMAS M. EARL

WITH IILUSTRATIONS

$49264 \div$

A. W. LIVINGSTWN'S GONS, PUBLISHEIS

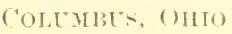




\section{(1) (a), II' \\ 14!!}

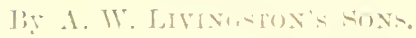




\section{PREFACE.}

TIIE publication of this work is lue to a constant demand for a popular but reliable treatise on the calle of pets. So much mismnderstanding prevails in regard to preserving healthy conditions in houschold pets that it seems apparent that some attention must be given to the acouisition of a knowlerlge of their neerls, if one really values the oljects under his charge.

The question "why do my pets die?" so trequently asked. may he radily answeped hy saying that the conditions requisite for health are not maintained. It may be true that the hereared owner has bestowed npon them every kindness, but kindness often finds expression in practices which must in the end provole mischief. Pets are as trequently compelled to suffer from misplaced kindness as they are from neglect, and when persons who are fond of their birds, or their fish, or their does learn to now this improptant fiact, the health and pleasing qualities of their farorites will he 1nolonged.

It is helieved that the present work emborlies the highest degree of reliable information that its condensed character will warrant, and both professional and amateur fancier will find much in a perusal of its pages to interest and instruct.

The Althor. 


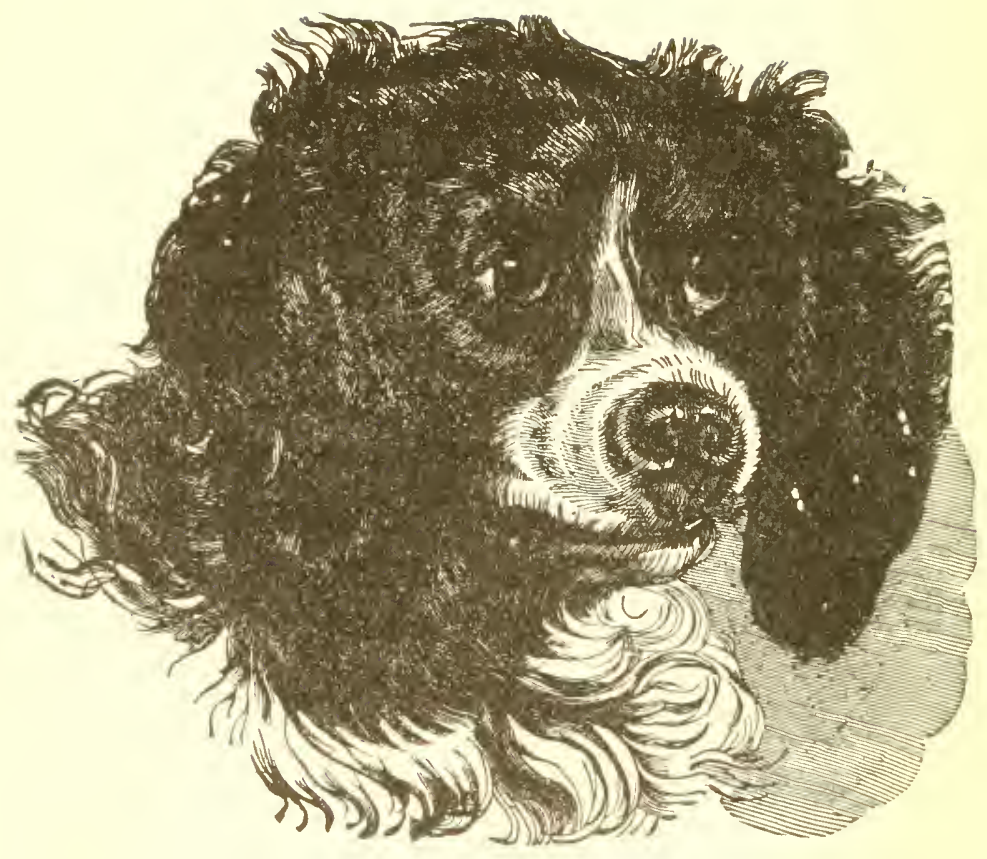




\title{
CONTENTS.
}

\author{
Cimapter I.
}

i'AGE

Cage Brnds-cieneral Obserrations. Trapping Birds. Bird

Cages. Food for Birds. Taming and Training. Dis-

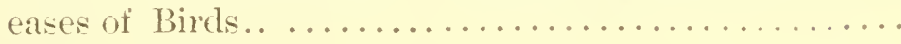

\section{Cinapere II.}

CAge Brons-The Canary. German Canary. Belgian Canary, English Canary. Bird-Breeding in Anerica. 22

CHAl'TER III.

Cage Birds-Care of Camaries. Pests. Drinking and Bathing Water. Seed and other Foods. Cuttle-Fish Bone and Grarel. Cayemne Pelper. The Moulting

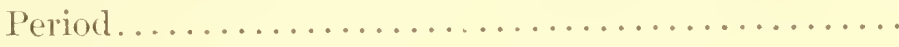

\section{CIIAPTER IV.}

Cage Binus-The Breeding of Canaries. Hybrids...... :8

\section{CHAPTER 1 .}

Calie Bros-The Diseases of Canaries: Asthma; Costiveness ; Loss of Voice; Diarrhuea ; Fits, or Conrulsions; Inflammation of the Intestines; Cramps and Lameness; Aceidents ..................... 40

\section{(Hapter VI.}

Cage Brros-European Songsters-I. seed-eating Birds: Goldfinch; Red Linnet; Bullfinch; Chattinch. II. Soft-biller Birls: Nightingale; Skylark; Black-

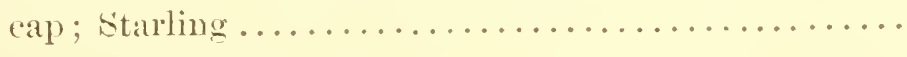




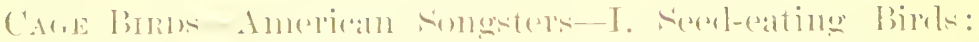

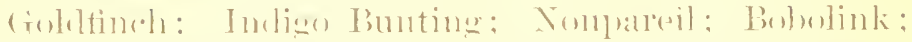

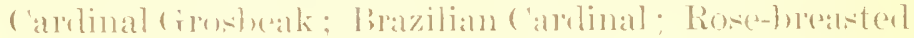

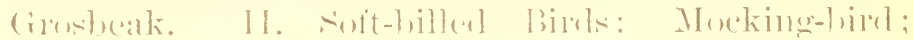

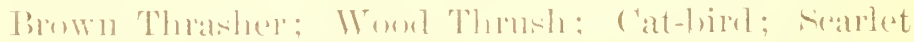

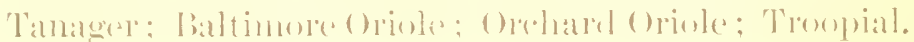

\section{('II.1Pli: YH].}

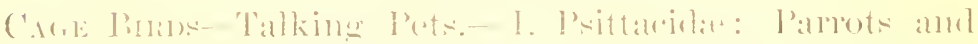

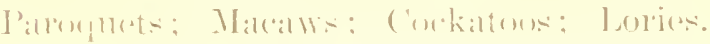

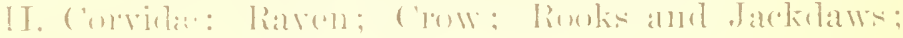

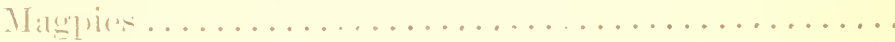

\section{('11. min IX.}

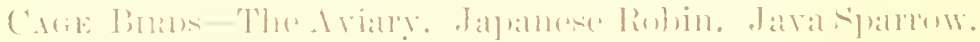

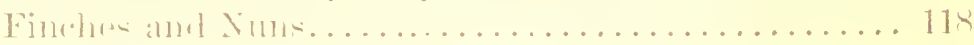



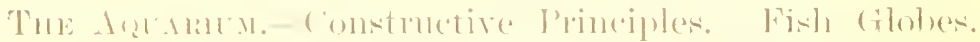
T:maks. I'lants. Water. Fish. Fording tha Fish.



\section{( 'IH MPTER X'.}

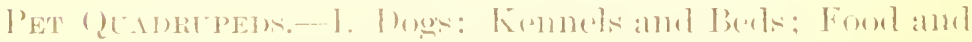

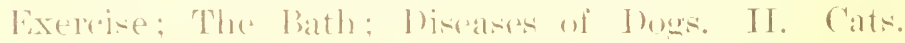

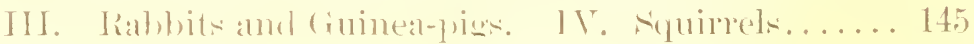




\section{CAGE BIRDS.}

\section{CIIAPTER I.}

\section{General Obeervations.}

HIE love of birds is coexistent with the love of flowers. When spring awakens by her

1 magic touch the flowers of the woodland, she calls forth, at the same time, from their sunny abodes the winged minstrels of the air, the former to delight us with their beauty and their fragrance, the latter to entrance us with their beauty and their song. As the wanderer in the woods, in search of early flowers, may feel impelled at times to pluck up by the roots some favorite plant, and to place it in his own cultivated garden, so the lover of birds may covet some feathered minstrel for the richness of its plumage, or the excellence of its song. This desire springs from man's love of the beautiful in nature, yet it is to be regretted that we are not always permitted to enjoy the bloom of flowers and the songs of birds in their woodland homes. Our habits in eity life render that impossible, and were it not for the transition of birds to city homes, many persons would be unfamiliar with such woodland nymphs. 
It is not necessarily an act of cruelty to cage a birl, as many imagine. Most imprisoned birds learn to love their new environs, and become fond of the persons who furnish them with their daily requirements, so much so that if given their choice between imprisonment and freedom, they will choose to return to the uges that have sheltered them, and to the caresses of the hambs that have ministered to their wants. The removal, however, of a bird from its natural home, where it has been able to care for its wants instinctively, imposes an important duty upon its possessor. 'To keep the feathererl pet in health and song, one must know, as near as possible, its perious manner of life, and seek to conform in its eare to its natural habits. To subject a birl, or other object, to a sudden transition in habits of growth, as well as in surroundings, would be crucl, and would prove, no doult, a task unrewarled ly good results. To imprison a bird in such a way that it is mable to care for itself, to neglect it, and cause it to languish for food or drink, and compel it to exist in an uncleaned cage, is a crime unworthy of ordinary civilization.

If, therefore, one owns a pet, let him provide for its comfort as he would for his own, seeing that its natural habits, as far as possible, are retained, then he may rest assured it will repay him with its 
measure of love, and an exhibition of all the gifts that its Creator has bestowed upon it.

Trapping Birds. Tarious means are employed by bird-catchers for supplying the demands for songsters. Few of these are bred in confinement, the Canary being probably the only songster that has experienced a long domestication. So easily are many birds taken, and so readily do they become, with proper attention, contented with the cage, that they are allowed to breed as nature directs them. The earlier in life a bird is caged, the more easily it is domesticated, consequently most birds are taken from the nest just before they are ready to $\mathrm{H} y$, and their feeding continued for a time by hand. Cage-life is then practically the only life they know, and such pets are usually docile and affectionate, being more highly prized on that account. By this method is kept up the supply of Mocking-birts which come into the market durng the summer months. The young which escape detection in the nest are often trapped by varions derices, in which the negroes of the South are usually expert. Most male birds are pugnaciously disposed toward any rivals that venture upon what they are pleased to believe their exclusive territory, and this tendency to resent intrusion and a supposed trifling with the affections of the opposite sex, gets 
many a beautiful songster into trouble. The trapper knows this peculiarity full well, and places in a cunningly devised trap a trained call-bird of the species he is seeking to ensmare, sets the trap wherever he suspects his victim to be, and awaits results. The bird he wants soon happens along, sees the intruder in the trap, or is attracted by his calls, makes haste to demand an explanation, or to executesummary rengeance upon him. To sooner, howerer, does he alight upon the perch placed for him than clap-doors are liberated by means of springs, and the would-be pugilist is a prisoner for life. Red-birds, Robins, Bobolinks, Indigos, Nonpareils, and many other birds, are successfully taken in this manner.

Another method of taking birks is by means of bird-lime. This is a mucilaginous paste, formed by boiling down the inner bark of the white holly, or sometimes linseed oil is rednced ly the same means to a pulp. Sticks are smeared with the lime, then placed where birds frequent, and results awaited. Should a bird alight mon one of them, he sticks fast until the hand of his captor releases him. If not soon freed from his predicament he will flutter himself to death. This means, with a number of rariations in the manner of procedure, is much used among the peasantry of Europe for taking Linnets, which usually alight in flocks, Golitinches, Chathinches, ete. 
BIRD Cages. 'The kind of a cage to be proeured for a bird will depend entirely upon the size of the bird and its habits in a state of nature. Birddealers have usually in stock a great variety of cages for the different classes of songsters, and in purchasing in this line it would be well to permit the dealer to designate the cage best suited for your purpose. Some birds sing better in small cages than in large ones, but in any case the health and comfort of the pet must be allowed suitable consideration. Brass eages are excellent for Canaries, and if properly eleaned will remain in a beautiful condition for a long time. Do not wash a cage of this kind with hot water and soap. Such applications affect the varnish, and will cause the wires to show milky spots or other imperfections. Scouring is still worse, as it removes the lacquer that protects the brass and that keeps it from corroding. Dampen a sponge in cold water, carefully: wipe the wires, and then dry with a clean cloth. If the varnish of a cage becomes injured from any cause, it may be replaced at a trifling cost. The perches of a cage should be just large enough to be grasped with ease by the bird. A diameter of about seven-sixteenths of an inch is right for a Canary. Small perches injure the feet, causing cramps or lameness. 
Foow for Birus. 'The proper diet to be given a cage-pet will depend npon the character of its natural food, or such as it would seek instinctively in a state of freedom, and its ability to feed upon various other substances to which it could never have been aceustomed. Food that would keep one bird in health and song would be entirely unfit for another; thus, hirds laving soft hills woukl starve to death upon seed that they would he eompelled to crack. Nature intended them to feed upon soft substances, such as forits, berries, insects, and the like, while birks with hard bills will tind their principal subsistence in the seeds of various plants and trees. All seed-eating lirds, however, will not thrive on the same kind of seed, nor is seed necessarily their exclusive food. Many require at times some of the insect food and sreen stuft that is given regularly to sott-billed songsters, in order that health and singing conditions may be preserverl.

The food best adapterl for the varions kinds of eage-songsters mentioned in these pages will be indicated in connection with their descriptions, but should information be desired concerning the food of birds not herein described, no great mistake can be made if general principles and a little good sense are followed. It is hardly necessary to state that seed and all other food for birds shonld be fresh and of the best quality. 
Hemp-seed is regarded more as a dainty than as a food for most birds. It should be rarely given to Canaries or similar songsters, but may be fed regularly to some of the large age-birds. It is very rich and fattening, and if much is allowed to a singing bird he will become too lazy to utter a note. Some hemp in the seel-nixture for Canaries is not, as some imagine, necessary to health; the other seeds are fully sufficient to preserve a well-nourished condition. Most birds are very fond of this seed, and will turn ont of their seedcups the other seeds in order to reach the hemp. C'anary-seed is a good food for most seed-eating birds, the best grade being the Sicily. It is nutritions and healthful when in a fresh condition, but stale seed of this kind is particularly injurious. Fresh seed may be known by the shiny and firm condition of the shell and the white, compact kernel; when stale, the shell is lustreless and the interior worm-eaten.

Rape-sced is largely nsed by the bird-breeders of Germany for Canaries to the exclusion of all other seeds. The grade known as the German Summer Rape is the best, and may be obtained from any reliable bird-dealer. The cheaper grades of rape are unwholesome, and should be avoided.

Millet-seed is fed to African Finches almost exclusively, and forms a part of the regular mixture 
for Canaries. The imported grade is the best, but the domestic can be recommended as good. It is a small, sweet seed, very nutritious, and as a regullar food can do no harm to a bird.

Maw or Poppy-sced is the smallest of all seeds used as food for birds. It is largely fed to Goldtinches, Siskins and Crossbills. Its properties are stimnlating and medicinal, on which account its use must be somewhat restricted. Birds are fond of it, and will sometimes feed upon it until intoxicated by the large amount of opium it contains.

Padda or Unhulled Rive is valuable for Bobolinks, Redbirds, Grosheaks and all lirds of very hard bills. Crushed corn is relished by Parrots, Macaws and Cockatoos, but since it does not contain all the necessary elements of nutrition, its use should be supplemented by other foods. It is likewise of a heating nature, and should be sparingly fed in warm weather.

Sunflower-seed may be ferl to Redbirds, Grosbeaks and Parrots as a favorite change in diet. These birds are very fond of this seed when tresh, and it is believer to be thoroughly wholesome.

The seeds above enumerated are usually fed in mixtures, thus affording variety in diet that stinulates the appetite of the bird, and at the same time aftords the several elements of nutrition. 'The best mixture for Canaries is made up of equal parts of 
canary, millet and rape, but no hemp. Maw, canary, and a small amount of hemp, is excellent for Goldfinches and Crossbills. For Cardinals, Paroquets, Parrots and Lories, take equal parts of crushed corn, sunflower-seed, hemp and unhulled rice.

Soft-billed birds, in a state of freedom, feed upon insects, worms, small fruits, berries and tender buds. In the cage a similar diet must be maintained. Since the Mocking-bird is one of the best known of the soft-billed varieties, the mixture that is prepared for all such birds is known as Mocking-bird food. This can be obtained of any bird-dealer, but many prefer to mix the food themselves. There are two kinds of this food-the moist and the dry; the first being always ready for use, the latter requiring the addition of grated raw carrot. In its dry form this mixture may be prepared by taking eight parts of pulverized maw-seed, one part of crushed hemp, four parts of cracker or stale bread crumbs, and one part of ox-heart, the latter being pulverized after a thorough boiling. Before feeding, mix a small quantity of the preparation with some grated raw carrot, or for young birds a better addition is hard-boiled egg and some mealy potato. Birds of the soft-billed class also require a constant supply of insects, such as flies, grasshoppers and spiders, while meal-worms and scalded ants' eggs 
are always aceeptable. Some green fool, such as lettuce, watereress, chickweed, or bits of sweet apple, are necossary for variety. As meal-woms are constantly required by many hirds, it is well to breed them and thus have an evor-ready supply. Half-fill an earthen jar with hran, or any kind of farinaceous meal, in which bury some pieces of old Hannel. Plane in the meal a sunall quantity of meal-worms-say fitty-amb rover with a piece of cloth, which shondel be dampened, from time to time, with water or stale beer. If left undisturber for a few montlis, thonsands of worms will take the place of the few introluced into the jar. Ants: egges may be olutained of dealer's: they shoukd be sealkerl before being fed to a birkl.

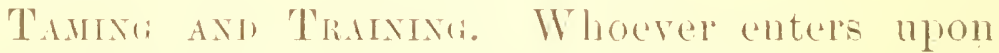
the difficult work of training a hird should have in store an unlinited sulply of tact, patience and perseverence. The intelligence of the average cage-pet is remarkable, but to accomplish its manifestation in actions that are alpart from the bird's natural haljits, is a task for which tew persons are suited. All birds, moreover, are not equally susceptible to training, owing to difference in temper and disposition, as well as in intelligence. The age of the pupil, also, must be taken into account. The Canary, owing to his long domestication, 
ranks at the hearl of birds capable of being tangth, and arnong trapped birds, none can excel in sunartness the European Gollfinch and the Linnet. Such birds as these may be taught to shake hands, ring a bell when they desire attention, draw up food and water, simulate death, climb the fingers presented in the form of a larler, fire miniature cannon, and many other amusing tricks.

There is a radical difterence in the way birdtrainers begin their instruction. By some, kindness and gentleness are enployed at all times, while other's consider cruelty as the only correct means. It must certainly be deemed wickert to use the latter means, and if a bird cannot be brought to understand what it is required to do by kindness, then do not attempt to train it at all. Some birds nerer seem to recognize their keepers as their friends; they are always suspicious of danger, and consequently any time lavished npon them will be wasted. A bird, to be trained, should be of a lively but gentle disposition, and the rounger the better. It must be kept near its trainer as much as possible, and its wants supplied by no other person. The first step is to gain the confidence of the bird, which nay be effected by gentleness, never frightening it by suddenly thrusting the hand into the cage, or endeavoring to catch it unnecessarily. A few hemp-seeds may be presented by the hand, or 
placel on a table just outside of the open door of the cage. Birds are very fond of this seed, and if none is allowed in the regular mixture, they will soon learn to pick grains from the hand, or venture outsicle of the cage for them. At night, when the bird is asleep, insert the hand quictly into the cage and by a touch awaken him. He will peck at the fingers, which should be withdrawn suddenly, as though the sudden peok was something to be avoided. After a tew nights of such experiences the pet will consider himself a conqueror, and will fight the hand in daylight. He will learn to shake hands, if his elaw is gently touched at night and the words "Shake hands" softly repeated. Give a hemp-seed as a reward for merit and proticiency, and let it be taken from the fingers or from between the lips. When a good start is made, the successive accomplishments of climbing the ladder of fingers, feigning death, drawing water, and the like, will be readily acquired. Good judgment on the part of the trainer will readily suggest expedients for bringing abont the desired results, the limits of this work forlodding a more extended description of details.

Diseases of Birds. It would be a mistake to suppose that birds in a state of nature are not subject to ailments, but it is true that when left to 
follow their natural instincts disease is a rare aftliction. When caged, the possibilities of derangements are largely increased, owing to carelessness or ignorance on the part of the keeper in supplying all daily requirements. Those that have "good luck" with birds are those who take care of them, and do not count it a task to provide ail the necessary conditions of health and song. Study the nature of your bird, and regularly attend to his wants, then the many diseases that prematurely end the existence of so many cage-pets will forget to put in an appearance, and sprightliness and pleasing song will be your reward.

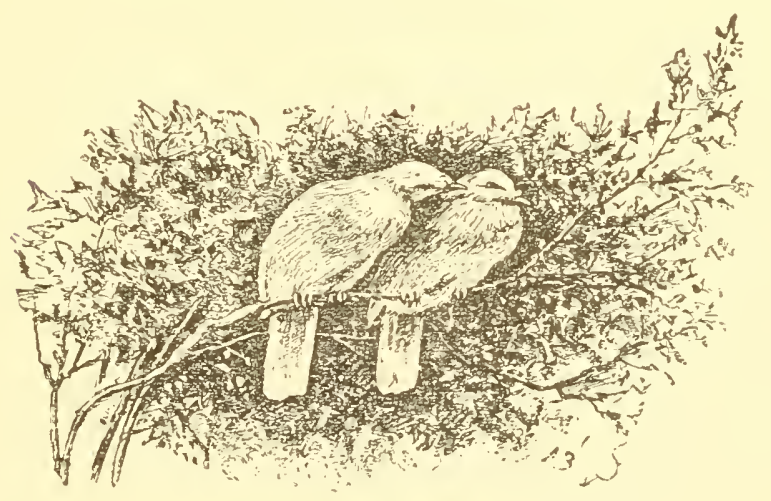




\section{(IIAP'TER II.}

\section{Tine Chans.}

TO species of bird las ever given so much satisfaction in the household as the 1 Canary. Ever since its introrluction into Europe in the sixteentl century, from the island in the Atlantic, the name of which it bears, it has been a favorite cage songster. Such perfection in the breeding of the species has been accomplished, that the domesticated bird now far surpasses the native stock in quality of shape, color and song, so that the latter is no longer drawn upon to supply the lirr-markets of the world.

The domesticated Canalies may be rivided into various classen, each sc] allately distinct trom the rest in song, shape, size or color-birl-breeders diftering materially in what they consider the requisites of perfect birds.

The Geman Caxamy. The people who have levoted the greatest attention to the rearing of Canaries are the Germans. By them the eultivation of the singing qualities of the bird has been 
almost the exclusive desideratum, no particular reference being made to beauty of plumage, shape or size. In consequence, the finest singers in the world are the trained German birds, not eren excepting the best of Nature's winged minstrels. The length of the German Canary is about five and one-half inches, the color varyng from a pure yellow to a yellowish green. The birds are sometimes rariously mottled or crested, for as before stated, their breeding las entire reference to their song and not to their plumage.

In many districts of Germany the breeding of the Canary, for the supply of the markets of the world, ss the principal occupation of the people, but the Hartz Momntain region surpasses all others to the extent that the German-bred Canary is designated by the name of that locality. The clnoicest breed is reared on the rery summit of the monntain, in the little hamlet of st. Andreasberg, where favored by the purest and most bracing of atmospheres, the hird-edncation is carried to a degree that can scarcely be understood by ordinary readers. Every facility is given for the young birds to acquire the cultured notes of well selected singers. Besides, varions mechanical derices are employed to introduce long trills, water and flute notes, and other oddities in song. From three to six nonths of constant training is needed to bring 
the young songsters to the required degree of perfection. Birls that develop harsh or crude notes are promptly ejected. St. Andreasberg Rollers is the name by which these Canaries are usually designaterl. As might be supposed, their extraordinary vocal powers make them very desirable pets, and they rightly deserve the high measure of regard that has been bestowed upon them.

The size of the St. Andreasherg Canary is about the same as that of the ordinary German bird, and its color and general aplearance are never more attractive, but when music is wanted and the soul is to be lifted from these meaner levels of thought and affection to the heights of seraphic eestacy, then let the feathered songsters that are prized for their beanty keep silence one and all, while the king of musicians the st. Andreasherg Canary executes his heavenly opera of song.

The Belaian Gaxaks. Shape in preterence to song has been the end songht for in the breeding of this birt. Belgium claims the honor of its greatest development, birk-breeding having been long a favorite loblhy with all classes in that country. The Belgian Canary is a long, slender bud approximating in shape whẹn at rest to a right angle, its head and neek horizontal, its legs and body rertical. Its movenents are awkward 
in the extreme, and its usual appearance gawky, but to the trained eye of the bird-fancier the marks of high breeding are everywhere apparent. When excited, or at a given signal from his keeper, the bird assumes the perfect position which shows its breeding to the best advantage. The birds of this stock, being of an exceedingly nervous temperament, are never caught. When their removal from one cage to another is desired, they are guided by means of a stick. In color the Belgian Canary is usually yellow, but color is made subordinate to shape. The full-bred bird is seldom met with in America, but three-quarter or half-bred birds are well prized, as they retain much of the beauty of the full-bred, and are at the same time better songsters.

The cage in which this bird is confined should be roomy enough for his lengthy figure. His food differs but slightly from that of others of his race. In addition, however, to the regular Canary seedmixture, the preparation of hard-boiled egg and cracker is recommended to be fed twice a week.

The Exglish Canary. The veople of Great Britain are not behind their continental neighbors in the matter of bird-breeding, but, unlike the Germans and the inhabitants of the Low Countries, the English have given more attention in the rear- 
ing of young birds to their color and size. The city of Norwich has given its name to the Norrich Canary, this particular farorite having been cultivated for years in or about that place. This bird is usually of a deep golden color, slightly larger than the Hartz Monntain species. Some sub-vari-

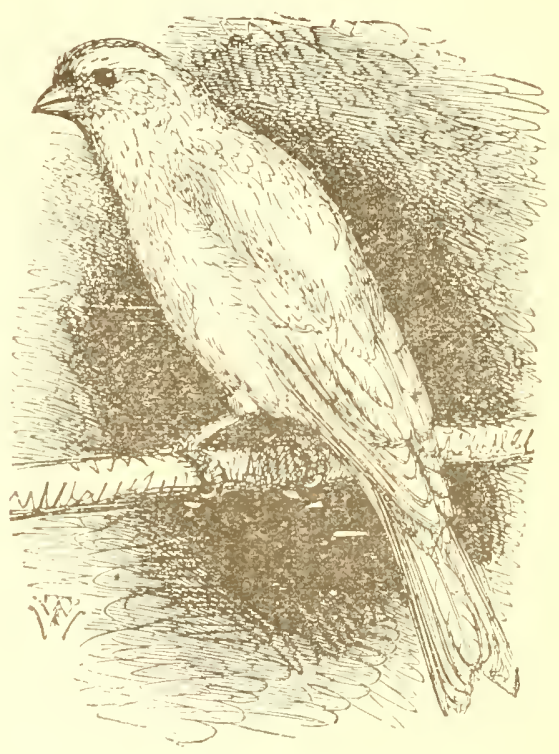

eties are splendidly erested. In song the Norwich Canary cannot compete with his German cousin. His notes are louder and not so well modulated as his rival's, nevertheless he does his best to be entertaining, and what is lacking in roice-culture he attempts to make up by spunk and ambition. 
Other varieties of the English Canary are the London Fancy, the Gold and Silver Lizards, the Scotch Fancy, the Yorkshire, Lancashire Coppy, etc. Of these the latter is the best known and the most remarkable. On account of its extraordinary size, the bird heing nearly or quite eight inches in length, he may be regarded as a veritable giant in the Canary race. "The word "Coppy" signifies a crest, an ornament which is characteristic of this species; a sub-variety, however, called the Plainhead is bred without a crest. The Lancashire Canary presents a very striking appearance, the borly being massive, yet graceful, the crest well proportioned and regular. The principal eftorts of its breeders are directed toward securing great size in body and crest, and good proportions in shape. The song of the bird is loud, corresponding to its size, and is not without its attractions.

The Scotch Fancy, or Glasgow Don, which, as its name suggests, is a favorite in Scotland, is an oftspring of the Belgian Canary, although generally more hardy, the same being true, also, of the Yorkshire breed. Excellence in shape forms the desired standard. No particular attention is given to the color of plumage or the quality of song. The English Lizard Canaries, so called because the peculiar markings were supposed to resemble those of a lizard, are handsome fellows, without 
exception the most beantiful of all bred Canaries. Every bird of this variety shows an attractive cap, which is uniform in color. This eap may be of a golden or steel-gray color, according to the variety, the body presenting a beautiful, spangled appearance, the result of a peculiar development in the coloration of the feathers.

Bird-brendiva in America. The busy pursuits of the American people seem to prevent them from entering seriously into the fanciful lastimes that chalacterize the life of the European peasantry. One of these, in which our countrymen are not expert, is bird-breeding; for while a few bird-tanciers may be occasionally found, who pride themselves in the pure stock of their birds, our breeders in general are content if eggs are laid and hatched, and the young grow up to be indifferent songsters. The American-bred Calnary has about the same relation to the European as the yellow mongrel has to the high-bred dog. Our birds are bred for pleasure and not for profit; but even pleasure would be enhanced if only the best stock were used in mating and science were to take the place of fancy in the methods of: breeding. 


\section{CHAP'TER III.}

\section{The Care of Canaries.}

入 OST of the wholesome directions usually furnished for the care of pet birds readily suggest themselves to the minds of intelligent persons. The best rule that can be given is to apply common sense. If left free to supply their own requirements, birds will follow the instincts of their nature, and when such freedom is denied them, their keepers are by duty bound to anticipate their wants and to furnish the necessary means of gratifying them.

Exercise is one of the fundamental needs of every active organism. Birds require it, but at the very outset of their career as cage-pets, it must needs be reduced to a minimum. Let the cage selected for a Canary be large enough to afford ample opportunity for flitting about; the larger the better, but no cage should be less than ten inches in diameter and twelve inches in height. Swings and rotating perches will afford much amusement to the occupant of the cage, as well as offer additional means of activity. Hang your Canary's cage in a moderately heated room and never where the bird will be affected by draught. 
Care in following this simple direction will remove a fruitful cause of death. If a cage should be placed ont of doors in pleasant weather, it must not he permitted to remain until the atmosphere becomes chilling. Fresh air and sunshine are grateful to a bird and necessary for its healthtul condition, but they must not be given at the expense of warnth.

Always kecp your Canary's cage scrupulously clean. This may seem a rather trite remark, lut uncleanliness is so very conducire to annoyance and disease in birds as well as in man, that this particular advice cannot be too frecuently insisted npon. If it prove to he too much of a task to attend daily to cleaning a cage and supplying its oceupant with the necessalpies of comfort and health, then do not lietp " livel.

Pests. A lack of cleanliness will enconage the breading of lice in the cage, and no cause is more fruitful of annoyance to the birk. When afllicted with these pests the Canary shows great uneasiness, plucks continually at his feathers, and appears generally wretched. If such a condition is observed, take down the eage and transfer its oceupant to another. Upon examination of the crevices and perches a reddish dust may be detected, or a whitish deposit as of Hour dusted 
()ver the surface. These may be parasites or their eggs, and call for a thorough renovation of the bird's domicile. If the cage is a brass one, the best way is to have it refinished; this will prove an effectual manner of getting ricl of the pests. Discard the perches, or pass them through the flame of a lighterl candle. On other than brass cages hot water and soap will be eftectual if tollowed by an application of varnish. Rest assured it is easier to prevent the coming of bird-pests than it is to bid alien to them. Before returning the bird to its cage, dust it thoroughly moler the feathers with German insect powder. 'This is usually eftectual in annilibating such palasites as may he upon the bipl's body. The little pet will soon resume its usmal sprightliness, and renew its singing. A gool way to detect the presence of lice in the cage is to cover the cage at night with a piece of elean white muslin. Examine this on the under side in the morning, and if there are insects about the bird, some will be found upon the cloth.

Drixking and Bathixg Water. Fresh water for drinking and bathing should be placed in the bird's cage daily. Drinking water which has been unchanged for several days may cause inflammation of the intestines, a tronble to which Canaries 
are particularly subject, and of which many die. The bathing dish should be shallow and the water for the bath of a moderate temperature. Few birds will neglect to avail themselves of bathing opportunities if these are given them about the same time daily. After the bird has bathed remove the dish, and give no further opportunity to bathe again during the lay, as too frequent ablutions sometimes produce cramps.

A persistent refusal of a bird to use the bathdish provided for him is often caused by a neglect to furnish him the opportunity to bathe at regular intervals. He will complete his toilet with water abstracted from his drinking cup, and utterly ignore his bathing dish, much to the chagrin of his mistress. For this condition of attairs there is often no help, but regularity in placing bathing water in the age, and. removing it after it has been there an hour or so, will do much toward inducing a desire on the part of the bird to make use of the dish at the proper time. Sometimes moderately spraying a bird that refuses to bathe, then placing him in the sunshine to dry and dress his feathers, will induce in him a desire for thorough ablutions. But care should be taken not to wet the birl's feathers too much, and never in a cold or chilling atmosphere. 
Seed and Other Foods. 'The best seed for' Canaries is a mixture of German summer rape, Sicily canary, and millet seeds in abont equal proportions. 'This mixture may be fed the year' round and should be the principal diet of the birds. Hemp is wholly excluded from this birdseed owing to its very fattening qualities, and notwithstanding the fact that all birds are fond of it, it should not be fed under ordinary circumstances. A few grains may be given possibly as a reward for purposes of training, or for building up an emaciated system. All seed fed to birds should be fresh and of the best quality; obtained, if possible, from a bird dealer, as that which is purchased from grocers is usually poor and unwholesome. Two or three times a week birds should have some green food, such as lettuce or cabbage leaf, chickweed, endive, water-cress, or a piece of sweet apple. Such food, however, soon becomes stale, and should be removed before it proves a means of injury. Cake, sugar, candy, figs and snch dainties should never be fed. A mixtme of hardboiled egg and pulverized cracker or stale bread crumbs is a valuable food under certain conditions, but birds in full health and song do not require it. This food may be given daily during the time of moulting. It may be fed regularly to breeding birds during the entire period of incubation, and 
should be the principal food of young birds until they are able to wark seed.

Cuttle-fish Bone and Gravel. The digestive organs of a lipd are so constituted that small partiCles of gravel are essential for a thorough grinding of the food before it enters the stomath. The bottom of a bird's cage shomld therefore be strewn with clean fine gravel from which the birl can pick at will, and in which it will often delight to sorale. cutthe-tish bone is finnished as an excellent appetiser. While not wholly neecsalry tor the health of the hird, its saline proportions remeler it wholesome, and a desirable aldition to the daily food.

Catexat Pepper. It has heen long generally known that the feeding of alyenne pepper to a Canary for a certain length of time before and luring the monlting season will materially alter the colop of the plumage; the change being to a very pronounced reddish-orange hute. 'L'his secret was guarded for a long time by its discoverer, who reaper a most splendid tinancial harvest for his good lute or ingenuity. Is such a change of color is produced by artifieial means, cayeme-fed Canaries cannot be classed as a distinctive species. 'The coloring, moreover, disappears when the bird monlts and the new feathers display their natural 
hue unless the feeding is renewed before the period of moulting begins. The pepper used should be of the best grade; that obtained from a reliable bird-dealer will prove nost satisfactory, as it is imported for this purpose. One heaping teaspoonful is thoroughly mixed with a hard-boiled egg grated fine, together with an equal amount of pulverized bread or cracker crumbs. The quantity of this mixture that a single bird will consume varies consilerably; the arerage amount to he fecl being one heaping tablespoonful each day. The regular seed-mixture should be reduced to half the amount during the cayenne feeding. Canaries are very fond of the pepper food, but care should be taken not to orer-do the matter. Enough wili prove better than a feast. The delicate organism of a bird might become seriously affected by overfeeding. It is thought by some expert birdfanciers that moderate quantities of the coloring mixture have no ill eftect upon the health of the Canary, while others assert that it is decidedly harmful.

The birds usually subjected to such artificial coloration have naturally a deep yellow color. The Norwich Canary is the very best of this class, its hue being to start with a beautiful golden. The feeding of the calyenne food is begun when the nestling is some six or eight weeks old and con- 
tinued until the moulting period is decidedly passed. The color should then be sufficiently set, but all birds are not equally affected by the food. Indeed, some Canaries do not seem to be noticeaby changed by all the pepper that they can be induced to swallow. In the second year, and in each succeding year thereafter, the pepper diet must be renewea about two weeks before the moulting period and continued until the same length of time after the bird has acquired his full plumage. Cayenne-fed Canaries, as a nsual thing, sing well, as pepper invigorates the vocal organs. They present a handsome appearance and are possibly as hardy and sprightly as others fed upon ordinary seed mixtures.

The Molmtixa Period. The shedding of a bird's feathers is a natural process that takes place annually; it must not be considered a disease, although carelessness at such a time in the matter of attention may jeoprardize the life of the bird. The moulting season usually begins late in August, and should be fully past in from four to six weeks. Nestlings have attained their full plumage when about two months. old, and very soon thereafter begin to shed their body feathers, those of the wings and tail being retained until the succeeding season. When the time for moulting begins a bird loses his sprightliness, stops singing, perches 
with his head under his wing considerable of the time, and shows no appetite for customary food. He should then have a more generous diet. In addition to the regular seed, feed daily a mixture of hard-boiled egg and pulverized cracker crumbs, to which a pinch of cayenne pepper may be added. The danger of taking cold is the greatest that besets a moulting bird. The cage may be partially covered with paper or cloth and hung where its occupant will be protected from draught and where a moderate, even temperature prevails. It is better also at this period to clean the cage less frequently, in order to prevent any unnecessary disturbance to the bird. A moderate degree of heat and sunshine will materially assist the restoration of the bird's usual appearance and sprightliness.

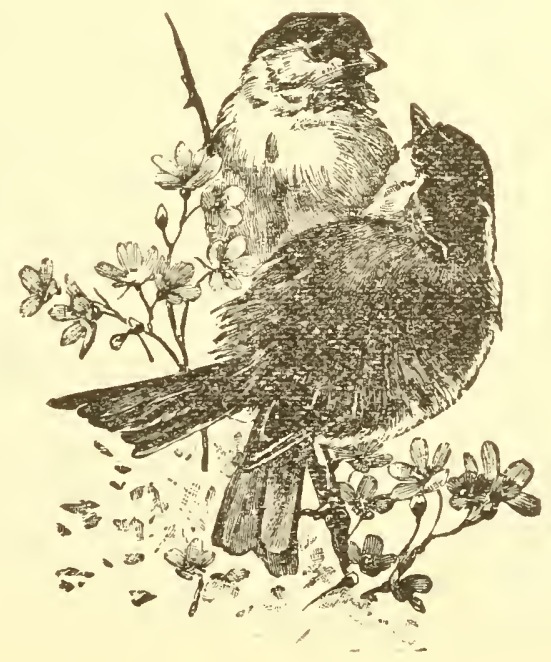




\section{CHAPTER IT.}

\section{The Breedint; of Canaries.}

7 HE rearing of young birds is a task in which all will not be equally suceessful, 1 but it is safe to say that if care is taken to follow a few simple dipections a reasonable amomnt of snecess may be assured to all. The breeding of Canaries may be commenced as early as February and eontinued until late in the summer, one par raising several l,rovels if permitted. The policy, howerer, of continuing the breeding season too long is to be displatiged as such continuation will prove detrimental to the health and comtiont of the birks.

The desire to mate is natural to a bird during the early spring months and if not permitted to do so, a slight illness known as the "mating fever" may ensue. This is most eommon in the latter part of April or the first part of May. The birl sometimes takes his condition seriously to heart, refuses his food, and reases singing. If mating is an inconvenience, the bird's cage should be hung in a cheerful place, where different surroundings may divert his attention, and it possible another 
singing bird should be placed near him for company. Talk to him and profter him dainties; the probability is that he will soon forget the desire of his heart and resume singing. A better way, however, at such a time, is to mate your bird; the trouble, it is believed, of ministering to the wants and looking after the domestic conditions of the hird family would be fully compensated ly the pleasant consummation of their household attairs.

Procure of your bird-dealer a female of as good a breed as it is possible to obtain; if older than the male, it will he all the better as the oftsplong in such a case will consist of more males than f'emales. If the parent birds are about the same age, the sexes in the young birds will jobably be equally represented. The colors of the young will be characterized by those of the parents. A thickly mottled bird may he mated with a pure yellow female to produce a progeny lighter than the male, but darker than the female; a fine yellow bird may be oltained by mating a leep yellow songster with a whitish yellow or mealy female. The singing qualities of the young males cammot be predicated from those of the parent. Excellence of song is the result of voice culture; it can only be attained by careful training during the period that the young males are begimuing to sing.

Birds will often quarrel considerably when they 
are first placed in the same cage. It is a good plan to give them a suitable opportunity of getting well accuainted betore they become occupants of the same domicile. Place the female in the breeding cage, which should he set or hung where it is to remain, and on the oplosite side of the room hang the singing Canary's cage. In a few days the birds will become quite familiar, the male calling and the female answering, and then you may be assurerl that they are ready to undertake the responsible duties of domestic life.

The cage in which the breeding takes place shonld be roomy, ten inches or upwards in width and sixteen or upwards in length. It should be hung against the wall or placed upon a shelf some seven or dight feet from the Hoor, and facing if possible, the south, as that will prove the most cheerful aspect. When once it has become the home of its prospective tenants, its position should not be changed, nor should it he needlessly taken from its place. The cage should be provided with a drawer which must be kept clean and strewn daily with fine gravel. It is especially to be desired during the breeding period to prevent the accumulation of lice as they are particularly annoying to the young birds. Cleanliness is a very certain preventative. Pieces of old plaster or crushed oyster shells should be strewn with the 
gravel in the bottom of the cage as the lime that the plaster and shells contain is utilized for the formation of ego-shells. Without this, soft-shelled eggs might be laid and such would be useless. Fresh water, both for drinking and bathing purposes should be supplied daily. Some birls will bathe during the breeding period while others will not; it is best to allow then to act accolrding to their own free will in the matter. Plenty of nutricious food should be given, as the cares incident to paternal and maternal duties are wearing upon the bird organism. Feed the egg and cracker mixture daily in ardition to the seed, and some green stuff, such as lettuce leaf or bits of sweet apple, frequently. This dict, indeed, should have been begun with the birls several days before they were placed together. Underfed birds sometimes eat their eggs as fast as laid, much to the annoyance of the breeder, but it is safe to say if the above mixture is ferl plentifully your birds will not cale to destroy their own treasures.

As soon as the male is observed to be feeding his mate, it is certain that the two have come to an amicable adjustment of their difficulties. In about eight days after mating, the female will begin to lay, and will deposit one egg daily until the whole number are laid. The set of eggs is seldom less than four, but often five or six and sometimes 
seven. Almost immerliately after the deposit of the last egg the female will begin incubation, a task in which she will be assisted occasionally hy the male, if he is a goorl huband. The first egg will hatch in exactly thirteen days, then one egg cach clay in the orler in which they were laid, until all the young birks are out. If an egg should be unhatched in two or three daysafter the proper perion for incubation is past, lift it ont of the nest carefully hy means of a spoon; hold it up between a strong light and the eye. If dark blood stains allear, retmrn the egg to the nest, for it may yet be hatcherl, but if it is semi-transparent it may he discarded at once. Loud noises near at hand, such as peals of thunder, the slamming of a door, the report of a wn, and the like, are said sometimes to kill the embryo, and render the egg worthless. The male will assist the female in feeding the young; plenty of soft food should he supplied them for this purpose, as the infant progeny have very large mouth and rery capacious stomachs, and notwithstanding the assiduons eftiorts of the parents they seem always hungry. The egg and cracker mixture should be their enstomary diet, and on this alone they will thrive, as it is very nutricious and well calculated to furnish the necessary means of development. In from two to three weeks the young birds will be able to leave 
the nest and avail themselves of the pereh. They will soon learn to feed themselves if plenty of soft food is kept in the cage. In addition to the egg food, some soaked, ripe seerl may be given regularly in a separate dish. When some four weeks old the males will be noticed swelling their throats as if attempting to warble, whereupon, if it is desired, the sexes may be separated. The birds will be in full feather when six weeks old, but very soon thereafter legein to cast their body feathers, and two months may elapse before they are in perfect plumage again. During this period, they should be carefully preserved from draughts, and fed the egg mixture daily, together with rapeseed which has been softened in water, and a little erushed hemp.

A young male's capacity to sing may depend upon good breeding, but the excellence of his song is dependent upon hismusical training. If he sings well, he has learned by imitation. If you expect your young birls to become good singers, you must place near them as good a songster as you can buy or borrow. A little money spent for a fine singer that can act as instructor to the young will be well repaid by the satisfaction you will get in knowing that you have not only reared a few broods of Canaries but that you have added to your possessions a number of excellent songsters. Bird- 
breeders in Germany put their Canaries to school immediately after the moulting season is past, the birks being then about three months old. A large number of young males are placed in a half-lighted room connected with an apartment above by an opening in the ceiling. In the npuer loom are placed the choicest singers that can be commanded -Nightingales, Larks, Blackeatps, etce, which act as instructors to the roung lirels. The Canaries soon learn the lessons so carcofully set for them, and in a few months beconne expert musicians.

IIaving now traced the ordinary routine of breeding Canaries, it will be well to note a few of the incidental annoyanees that may oc*nl to mar the pleasure of the heeder. Ocanionally a male bird is eapricions about bestowing his aftections npon the bricke that has heen chosen for him, and sometimes the female will resent all attentions that may be proftered her by her liege lorl. It the birds refuse to mate on aceount of any coldness of heart on the part of either of them, find ont which one is at fault and then change the bird.

When a female has trouble in laying hel egg she is sald to be "egg-bound." This condition is frostrating, and if the egg is not laid within a reasonable time some expedient should he tried to bring about the desired result. Take the hird gently in the left land with her back to the palm, and 
expose the passage to the steam of a kettle for a few minutes; apply with a pointed stick a drop or two of sweet oil to the rent, and return the bird to the nest. It is probable that the egg will be laid immediately. This condition may be prevented by feeding daily plenty of green stuft for a time before the birds are mated.

It may happen that the male and sometimes the female parent is guilty of eating the eggs as soon as laid. This fault is said to result from underfeeding. The birds should have extra nutriment from the time that they are placed together and as long as they are acting in the function of parents. If however the breeder is likely to experience this annoyance, the eggs may be remored as fast as laid (using a spoon for this purpose) and small marbles substituterl. When the entire quota is laid, the eggs should be carefully returned to the nest as the hen will hegin incubation at once.

After the eggs are hatched too much curiosity on the part of the people of the household in displaying the interesting progeny will sometimes cause the bird parents to desert the young. Leare the birds unmolested as much as possible. If then they persist in failing to feed their oftspung the latter must be fed by hand or left to perish. Remove the nest with the young birds in it fiom the cage, taking care to keep them wam, then feed 
them every hour during the day with the egg mixture previonsly recommended, using for the purpose a small stick or quill. A Red-bird placed in the same carge with a nest of deserted Canaries will sometimes perform all the duties of a foster-parent. He tenderly supplies then with all they desire, and acts besides in the capacity of musical instructor.

A hen may eover her young too elosely during the first few lays and so "sweat" them; at the same time she is likely to neglect their proper feeding. It may be well in such a case to remove her mate from the age, thus compelling her to leave the nest tor foorl. The sight of plenty of fresh foor in the dish and of the gaping monthe of her young nestlings will wsually be sufticient to sugerest her duties as a provider.

IIýrins. A hylpicl or mule-lipel is the oftisuring of a mate of one species and the temale of another. some frersons have a fancy for such breeding; inceed, it must he ackmowledged that the difficulty of producing desirable variations in species is not withont its special attractions. All hybrids are incapable of reproduction; any attempt to mate them would necessarily prove futile. The female Canary will mate with the males of many species similar in habits to herself if the opportunity of mating is given during the natural pairing season 
of the male bird. The females also of many varieties less domesticated than the Canary will mate with the male of the latter species. 'The Goldfinch, Bullfinch, Chaffinch, Linnet and Siskin among European birds, and the Goldfinch, Bobolink, Indigo and Nonpareil among American species, will mate with the Canary. The proper time of breeding for most of these varieties is about the middle of May. The American Goldfinch is exceptionally late in mating in its natural state, as it is often late in the summer before its first brood appears. The breeding of hybrids will be found more difficult than that of Canaries, although the same general pules will apply to all. High colors are sought for in mule-breeting, and the song resulting from combination is sometimes excellent.

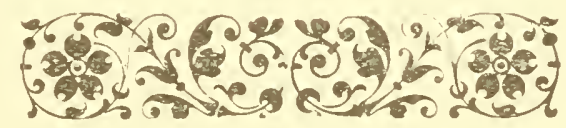




\section{CHAPTER T.}

\section{'THE DIsEAsEs OF CaNARIES.}

7 HE Canary is a remarkably healthy bird, living many years if proper attention is 1 giren to its requirements. Disease or premature death must be attributed usually to neglect, a statement which has heen made with equal truth respecting age-hirls in general. Over-kindness, however, and eonsequently orer-indulgence in the matter of feeding, often lays a foundation for future trouble. Simplicity in food is one of the secrets of long life in pets as well as in the lumman race, yet this statement in no way contlicts with the timehonored saying that "valiety is the spice of life." Changes in diet may be marle from time to time, hut whatever is fed should be simple in its nature, and caleulated to nomish the bird-organism. If you would have your hird " live to sing," it must be marle to "eat to live," ambl not to "live to eat." Cake, candy, sugar, and varions other swectmeats, are wholly moknown to hirds in a state of nature, and shomld be rigoronsty exeluded from the daily memle 
Cleanliness and a care to exclude stale food and water from a cage, will sare its occupant a period of suffering, and, perbaps, its fond but indulgent owner a temporary heartache. A few of the principal troubles to which Camaries are subject will be briefly enumeraterl, and the remedies usually found sufficient for the same will he given. It may be remarked, in this connection, that the diseases of other cage-birds are, to a large extent, very similar in their nature to those of Canaries, and may be treated by the same means as recommended here, unless otherwise specitied in the proper connection.

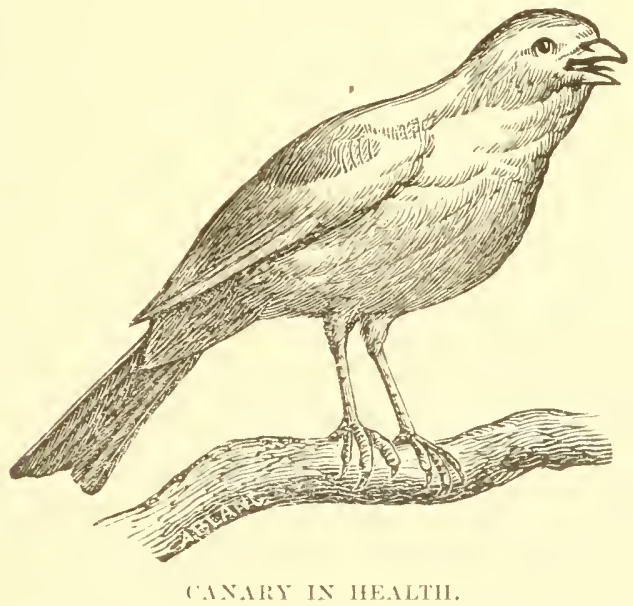

Taking cold is a fruitful source of rlisease, being usually due to negligence. A bird's age has been hung in a draught, or placed out of doors during the sunny part of the day and forgotten until after 
the sun lias gone down, or, perhaps, allowed to remain ont atl night. The morning finds you with a wheezy bird on yom hands, if not with a dead one. Colds produce asthma, comsmmption, loss of voiee, diarrhora, and other kindred troubles.

Many birds of a greedy disposition are subject to indigestion. Their alpetites may have become vitiated by the feeding of lainties, or, after a period of neglect. too much food is given at one time, from whidh they greedily appease their hunger. l'erhaps the drinking water has hecome stale, or a hit of apple or green stutt has somper, and has not been removed from the ange. From such causes arise constipation, fits, inflammation of the liver or bowels, from the latter of which many birls die. Uncleamess or a foml atmosphere may canse cramplis, sope teet, varions diseases of the skin, and, where many hipls are confined. some eontagious diseases.

Astunt is nsmally the result of cold, hut may, in some cases, arise from incligestion. It is characterized by difficult breathing, the aftlicted bird opening his montl, frepuently to gass for air, and prodncing. from time to time, a peculiar wheezing. Place the cage where thele is as even a temperature as possible night and lay (70 is about right), and see that the birl cammot be atteeted by dranghts. A 
bird's cage is frequently hung upon a support fastened to a window easement, and it sonietimes happens that the window sash is rery loose. Through the crevices comes a constant flood of cold air, which may not be perceptible to persons in the room, but which means death to the bird. Make sure that such conditions do not exist. Reduce the bird's liet to plain rale and a few canary-seeds, from which all dust has been earefully removed. Plenty of bread, soaked in water and squeezed until the surplus water has been remored, may be fed daily; or bread boiled in milk will be better. Feed lettuce leaf, endive, watercress, or other green foorl, two or three times during the week, but remore the remuants from the cage before they become stale. Hang in the cage a piece of tat, salt pork, mneooked, at which the bird tall pick at his pleasure; sprinkle the pork slightly with cayenne pepper. Birds suffering from asthma should not be caught if it is possible to aroid it.

Costruasess often aftlicts birds recently bought. They have been fert on dry seed alone, and have had no means of exercise in their small cages. A bird often manifests this trouble by frequent switching of the tail, and efforts to obtain relief. The feathers are rufled in appearance, and the bird shows a general mneasiness. A'permanent enre of 
constipation must be brought about by correct feeding; temporary relief may be eftected by giving a piece of stale bread, moistened in sweet crean, then sprinkled with maw-seed, or administer a fiw drops of castor oil. Sweet apple and some green food, given several times each week, will prevent this trouble.

Loss of Vorce is sometimes the result of cold, and sometimes of over-singing. This condition is seldom lasting when it receives proper attention. Give a more generous diet for a short time; it is well to feed the egg-mixtmre, sprinkled with cayenne pepper, and to dissolve a small piece of roek candy in the drinking water ealch morning.

After the monlting process is fully over, a loss of voice is sometimes observed to affect a singing bird. He may be ambitions to resume singing and indeed may go through all the motions as usual lunt not a somur is hearl from his throat. This endition is oftenthe result of cold contracted during the monlting priod: the above remedies will pobably prove eftications. A piece of raw fat hacon hong in the cage is excellent.

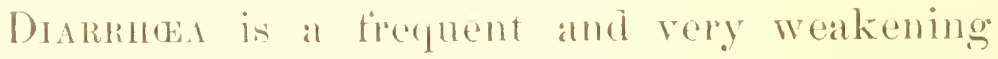
complaint anong birls. It often affects those that have been newly trapped, and in many cases proves 
fatal. The principal cause of diarthara will be found in the manner of feeding, althongh the trouble sometimes results from a cold. Green foorl, too frequently fed, or permitted to be eaten in a decayed condition, or foul drinking water, or too much sloply food, are all conducive to the disease. It is made manifest by the watery character of the bird's droppings, and calls for speedy relief. The simplest remedies are as follows: Place a rusty iron nail in the drinking water, which must be given fresh at least once a day; withhold green food for a few lays, and with the gravel on the bottom of the cage sprinkle cayenne pepper and some chalk grated fine. Keep the cage thoroughly clean, placing it where the hird will be warm and dry.

Fits, on Coxvusans are probably due to indiscreet feeding, and will yield, usually, to a correct diet. Feed, for a time, rape-seed with a little canary, but no hemp. Beware of all sweetmeats whatsoever, but give plenty of lettnce or sweet apple. Never hang a birl's cage in the hot sunshine: to this fault may be attributed some epileptic disturbances rather than to indigestion.

Some bird-fanciers assert that fits are usually if not always due to prolonged constipation. If such a condition is known to exist the remedies 
for costiveness should be applicel and great care exercised in dieting.

INFLAMMATION OF THE TNTEATINES. This is a dangerous trumble, and if not checked at the outset is likely to cause death. Like some of the foregoing diseases, it las its origin in bad feeding, and a consequent derangément of the digentive organs. Inpure drinking water, had seexl, or stale food of any kind, are fruitful causes. The hird shows sympltoms of pain, sarcely cares to move or perch himself erect, has no alluetite for food, lut evinces sreat thirst. If the sufterer be gently canght, and the feathers parted over the aldomen, that region will he seen to show a reddish hue, varying in lepth of color with the intensity of the disease. Adopt hy gienie meanures at once; crackers or stale hread, soaked in milk, may be ted to the exclusion of other food for a lay or two. A warm application, to the abdomen, of tuppentine and lard will afford relief. Absolute cleanness, a moderate tenperature, and freedom tron all excitement, may bring the little sufferer back to health. During convalescence a nourishing diet may be given. Some bird tomics, to he obtained in the stores, will be found useful.

Cramps and Lamexess. Cramps are the result 
of too frequent bathing, filthy or ton confining cages, or of' indigestion. The legs, if' affected, may' be immersed in a warm batli; a few drops of landanum placed in the drinking water is beneficial. Lameness is due to the use of perches too small to be conveniently grasperl, or, perhaps, to filth. The scales on a bird's legs, which increase in thickness as the bird increases in age, sometimes produce lameness, and should be removed. First soften them by the aid of glycerine, used as a lotion; in a conple of days they may he removed by means of a knife-blacie. A bird's nails should not be permitted to grow unnecessarily long. When they appear to need trimming, gently catch the birl, and holding the claw up between a good light and the eye, so that the blood veins may be discerned, clip away with sharp scissors the superfluons nail, taking care not to draw blood by cutting into the quick.

Accidents will happen in the lest regulated families, and these sometimes oceur to one's feathered pets. Should a bird become badly injured and its recovery doubtful, the most merciful means of freeing it from its suffering is by the use of chloroform. Make a stiff paper cone large enough to corer the bird; a few drops of chloroform placed therein alcong with the injured bird will cause a painless 
and speedy deatlı. In the case of ordinary injuries the cage should be hung in a warm, dry place; place food and llink in an aceessible place, then leave the sufferer to himself. Quiet and nature's healing balm will, in a few days, restore the invalid to his usual sprightliness.

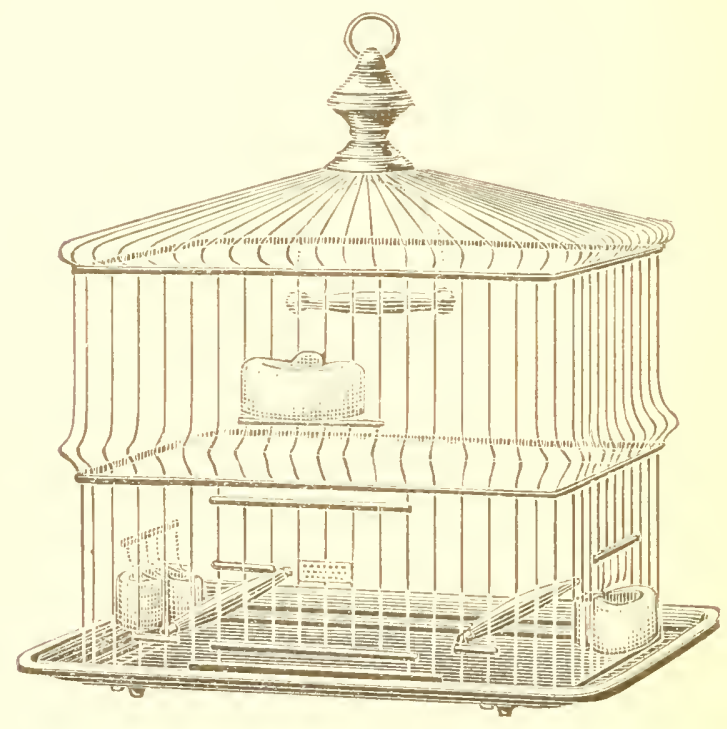






\section{(IIAPTER VI.}

European Songsters.

DHE ornithological fanna of Europe includes some of the finest songsters of the world. They have, from the earliest times, been celebrated in prose and song, and the names of many of them are as famihar to American readers as are those of our own worthy minstrels. Who has not heard of the Nightingale, the "sweet Philomel" of the poets, who have loved to sing of his enchanting melodies poured forth in moonlit groves, and of the Skylark, that "ethereal minstrel, pilgrim of the sky," whose morning hymn is chanted in ecstatic flight. 
The Enropean birds are, as a rule, less brilliant in plumage than our Ameriean songsters, but if the former are lacking in beauty they are certainly wortly rivals of their neighbors aters the sea in song. Quite a large number of the European birds are desiralule as cage-pets and for the aviary. Nueh attention is given in the Old World, by the common people, to the domestication of native songsters, and probably to their love of such pursuits is due the fact that large numbers of cagebirds are anmually imported into this country. Such of the peasantry as follow sedentary ocenpations-tailors, shoemakers, weavers, ete, are oftentimes expert lojed-trainers, and realize handsomely hy the sale of such feathered pets as they have, firom time to time, in training.

\section{I.-Seed-Eating Biris.}

Golufaxcu (Carductis carduplis). The Goldtinch. is one of the handsomest and heservedly one of the most popmlar birds of the Old World. Large numbers of these Finches are anmully trapped, and owing to their easy domestication, their musical proficiencies, agreeable manners, and aptness to acquire smart tricks, they find a ready market the world over. 'The extreme length of the birl is five and one-half inches; the bill is tipped with 
black, and encircled at its hase by a beautilul tringe of bright scarlet feathers; the top and back of the head and a band extending on either side, just forward of the shoulders, are black; the cheeks and throat are white; the back, shonklers and breast a tawny brown: the rump, wing and tail feathers black, those of the wing being tipped with white, and their black relieved by bright patches of yellow. Tle seems fond of his beanty, and loves to dress his feathers and cleanse them with a daily bath.

The Goldfinch, when trapperl, shows little anxiety concerning lis new mode of life. He is always a happy fellow, and, like all haply fellows, arlapts himself readily to his surroundings. He soon strikes up a lasting friendship with his keeper, and inwarlly vows to jure himself worthy of all the kind attention bestowed npon lim. His song is mellow and pleasing, but lacking in force; in confinement he will sing most of the year, the principal exception being the moulting season. With a lively and chaming motion of the body he utters his pleasing melody, the overflowing of a heart in which calre has no abiding place.

This Finch is one of the best trick-birds of the world. His apt intelligence enables him to acquire the habit of drawing up his seed in a bucket, firing cannon, climbing the fingers, feigning death, ring- 
ing bells, and many other snart things, in all of which he is rarely equalled by other birds.

Ilis daily tood in confintment is maw-seed, slightly mixed with canary: a fuw grains of hemp may be occasionally given him as a luxury, or an a reward for meritorious proficiency in learning. His daily bath shonlh he ly no means neglected, as bathing is one of his greatest pleasures. Mis general treatment is similar to a Canary's, and his diseases, which are few, may be relieved or prevented by preserving hygienic anditions. The male Goldfinch mates realily with the female Canary, the progeny being said ly some anthorities to be productive. This is not the ase with hybrids in general, but since the follfinch is nearly allied to the Canary. which is also a Finch, such an exception to the general rule may obtain.

Reu Linnet (Fingilla linota). The Linnet, like the foregoing species, is a particular favorite with all elasses in Europe, its sweet, well-modulated song and docile manner making it a desirable cagepet. Linnets are very sociable in disposition, and large flocks are often seen perched on the top of some favorite tree, warbling and chattering in a most happy and engaging manner. They are easily taken by means of bird-lime or clap-traps, and readily adapt themselves to a cage existence. The 
Linnet is said to acquire readily the notes of other songsters with which it is confined, yet its own song, so sweet and naturally varied, is by no means improved by the combination. The habits of the Linnet are so nearly like those of the Canary that the same treatment may be given it in health and disease. In its natural state the bird is very fond of bathing, and no opportunity is lost to bathe and dabble in every wayside rill, then to dress its wet coat in the sunshine. In intelligence the Linnet is little, if any, behind the Goldfinch, his ability to acquire amusing tricks being rery marked. He is hardy, quite free from diseases of any nature, and will pipe his sweet and pleasing song at most seasons of the year.

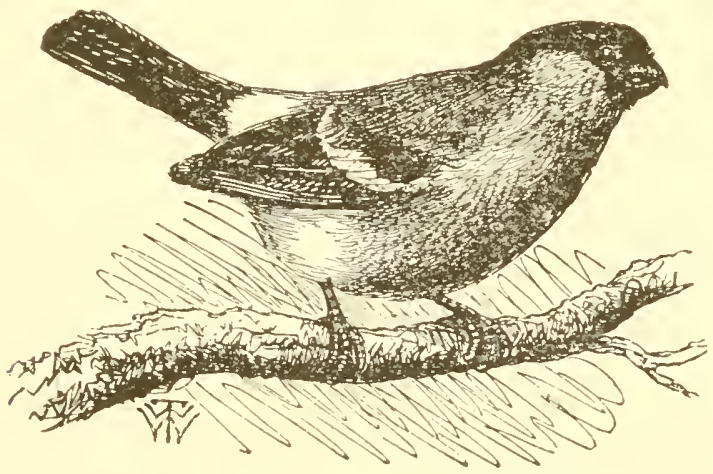

BLLLFINIH.

Bulufincu (Loxin pymmla). The Bulltinch, though possessing naturally few notes entitled to consideration, is one of the most highly 
prized of all eage-bires. His merit lies in his ability to pipe difterent musical strains that are whistled to him by expert trainers. In Germany, in particular, feasants of sedentary occupations make a specialty of training Bullfinches, and from them are obtained by bird-traders the piping birk that are sent to all quarters of the globe. Birds intended for the Anerican trade are tanght the "Star Spangled Banner," "Yankee Doodle," "ILail Colmulia," ete, which they execute with acenracy and sweetness; while snch birds as are to find English lones will pour forth the strain of ". God sare the Qneen" with equal patriotisn and vim. The Bullinch is a heatitul bild, in appearance very neat and precise. The bill is quite short and stout, being blark in color; the crown of the head is hlack, and a narrow, black rim of feathers encircles the bill; the greater part of the body is a hamblsome ehestunt in color'; the wings and tail are black.

The natural food of the Bullfinch is the seeds of plants and trees. Ile exhibits, likewise, an munsual fartiality tor the tender fruit-lunds in farmers' orehards, for which reason he is considered by agrieulturists one of the most pernicions of birdpests. In the cage his principal food should be a daily supply of fiesh rape-seed, and a very few grains of hemp oceasionally. Fresh green food 
may be given him two or three days in the week. but the remuants of such food should be removerl before they beeome stale. It is best that the Bullfinch should be cared for by the same perwon day after day. A strict diet of wholesome food, all dainties being carefully excluded, will go far toward preserving the healthy condition of the bird. The Bullinch monlts so rapidly that he is almost devoid of feathers at trmes; he should accordingly be well shielded from dranghts, his cage being hung in a warm, dry place. During the period of moulting the bird will not sing. He shonld receive at that time a more generons diet of strengthening and stimulating food. A rusty nail placed in his drinking water will have a wholesome effect, and this may be clone at any time that the birl shows a tendency to diarrhoa, a disease which trequently affects him. The claws of a Bullfinch grow rapidly, and should be trimmed whenerer their length seems to be a hindrance in leaving the perch. He should not be frightened, nor caught nuncessarily. While he is more subject to diseases, probably, than some other birds, it is nevertheless true that proper eare will prevent any discomfort in his life, or discontinuance in his song, other than the exceptions noted in the natural process of moulting.

Chaffinch (Fringilla caclebs). The Chattinch is a favorite eage-bird in some parts of Continental 
Europe, but the English lo not value it highly, as it remains in song only a part of the year. Early in the season, while winter still lingers in the lap of spring, the sweet song of the Chaffinch may be heard on every hand, a pleasing intimation that sunshine and good weather are close at hand. During the spring, and until the midlle of the

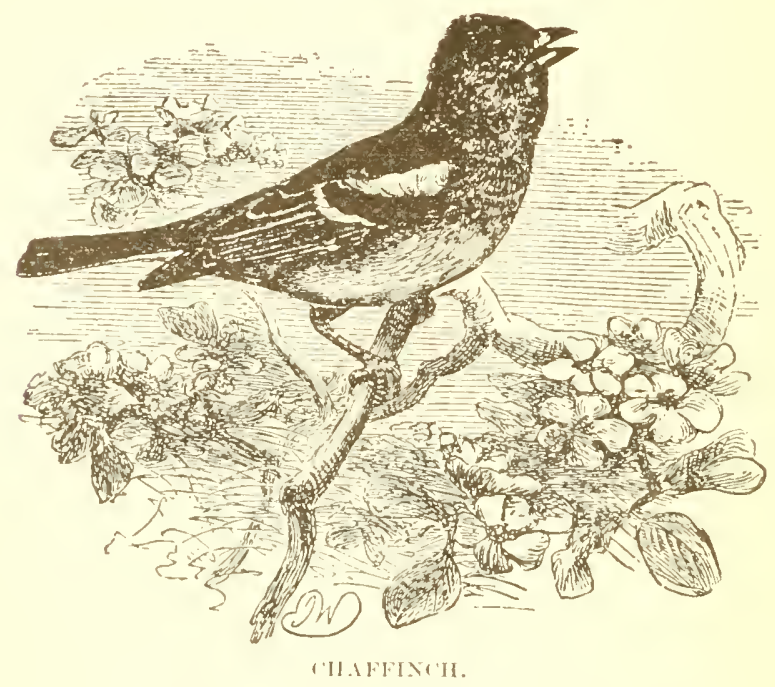

smmoner, the warblings of this hird are frequent, the first lieard of all the songs of the vernal and natin choristers. During the remainder of the year he is entirely silent, and no circumstances seem sufficient to call forth one note of melody. In the Low Countries a great ant of eruelty is perpetrated upon the cagerl Chathinch. To prolong 
his powers of song, his eyes are seared out with a hot iron, and the unfortunate chorister is doomed to a life of $\mathrm{gloon}$.

"How the song of birds is involved in mystery: Mystery pobahy never to be explained. While sauntering up and down the continent in the blooming month of May, we hear the frequent warblings of the Chaffinch: and then we fancy he is singing solely to begnile the incubation of his female, sitting on her nest in a bush rose at hand. But on returning to the town we notice another little r'haflinch, often in some wretcher alley, a prisoner with the loss of hoth his eyes, and singing nevertheless as though his little bealt would burst. Does this bliml ealutive pour forth its melody in wrder to soothe its sorrows: Has omnipotence kindly endowed the thatlinch with vocal farnlties which at one time may be employed to smplort it in clistress, and at another time to arld to its sorial enjoyments:" What answer shall we make? We know not what to say ; but be it as it will. I would not put out the eyes of the poor chaffinch, though by doing so I might render its melody ten times sweeter than that of the sweet Nightingale itself."-W Itertox.

\section{II.-Sort-Billed Birds.}

Nightenciale (Plilomelaluscinia). Although universally esteemed for his musical capabilities, the Nightingale is deroid of all attractiveness in appearance. "Nature," says a writer, "has compensated for its plainness by giring it a roice irresistibly charming. Listen to its fine, long, quivering notes. What variety, sweetness and brilliancy in them! It seems to sturly and compose beforehand the melodious notes it wishes to be hearl. It begins softly; then the notes swell gradually, till they run with the torpidity of a torrent: it goes from serious to gay, from simple notes to the willest warbling, from the lightest turns and shakes to lauguishing 
sighs, and has throughout the whole the art to please the nicest ear."

The habitat of this hird includes nearly the whole of Europe and a protion of Asia, some of the warmer conntries being larticularly favored hy his presence in abundance. Pleasant groves near running water's are his hamnts, and there h's "most

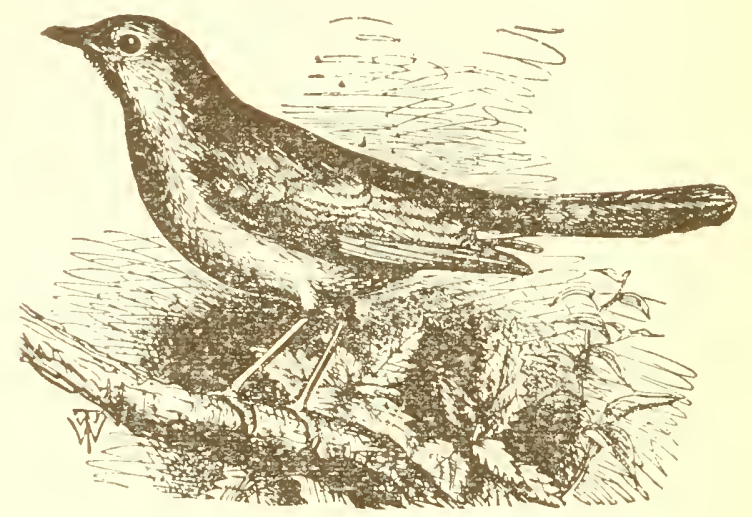

NIXITINiATE.

musical, most melancholy" notes are very sure to be heard after his arrival in the spring. At night, when other songsters are silent in repose, this king of musicians reigus supeme. Anxions to please his mate, he exerts his strength of voice to the utmost, and so beguiles the weary hours of darkness. The Nightingale is easily trapped, and with proper care he may be kept in song during the greater portion of the year, although his choicest music will be produced during his natural mating 
season. He may often be incited to sing when otherwise silent, by placing his cage near that of another songster, whose music he will zealously attempit to silence. He is a voracions feeder, and not only enjoys, but requires, a good variety of rich food. The prepared Mocking-bird food should be given him daily, and ants' eggs, previously soaked until soft, may be adiled. Meal-worms are much relisherl, and when fed several times during the week, will do much toward keeping the bird in song. Ripe fruit and berries may also be given frequently in their season, but must not be permitted to remain in the cage after they have become stale. Utmost eleanness and daily supplies of gravel and water will not only aftord comfort to the bird, but will prevent an annoying complaint, that of sore feet, to which he is quite subject. Those who have been successful in keeping a Nightingale tor a long tine in confinement, are of the opinion that the diseases that are apt to end his career as a cage-pet are due to ignorance or neglect in feeding.

Skiqark (Alunduarefnsis). Scarcely less famous than the Nightingale, the Skylark is more generally diftused over the whole of Europe, and familiar to all elasses. Unlike neally all other songsters, his sweetest music is producerl when flying. Leaving 
the mearlow's breast at the first intimation of the approach of the king of day, this sweetest of all matin minstrels cleaves the air heavenward, singing as he soars, until his form has disappeared from view. As a cage-bird the Skylark is a great favorite in Europe. He is remarkably hardy, a prime feeder, and quite docile. He sings well in confinement, but his cage should be adapted to his natnral lablits. One with a semi-circular and revolving front is especially manufactured for the Lark, and should always be proenred for him. No perches are necessary, as this bird always rests on the gromurl. The roof' of the ange shonld be covered by a cloth, in order to prevent this aerial songster trom injuring hinself, for true to his natural habits, he attempts at times to soar, but discovers in an abrupt manner that his surroundings are unfavorable to such sport. Green sod should be kept in the semi-circular apartment of the cage, upon which he will delight to rest and to warble lik sweetest songs. The skylark nevel bathes, and a hathing dish is, therefore, an unnecessary piece of furniture. Instead of a water hath, he loves to dust himself in fine sand, after the manner of domestic fowls, and thus, strange to say, he keeps hinself clean and free from insect pests. II is regular food is the Mocking-bird mixture, prelared with raw grated carrot, lilenty of fresh reg- 
etables, and some seeds. Insects he will relish at all times, and these may be given him quite freely, without fear of surfeit. Inrinking water, of course, he needs fresh daily, and plerty of tine sand for his bath. His cage should be placed ont of doors when the weather permits, as sunshine and fresli air will renind him of his native heaths, and thereby incite him to song.

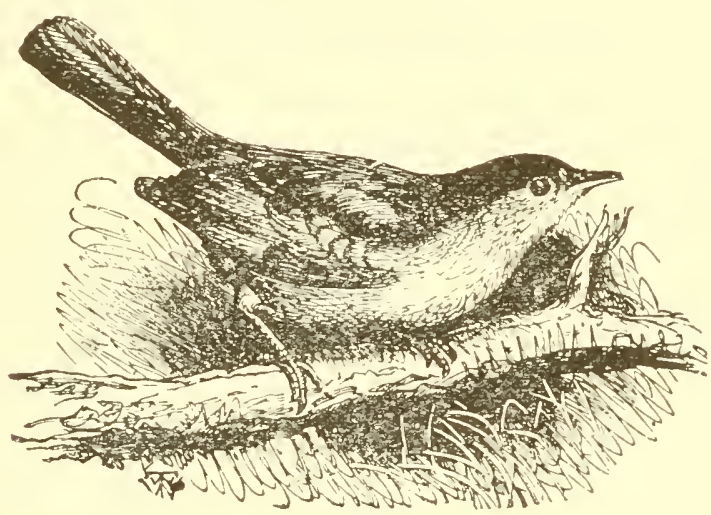

BLACKC'Al'.

Black-cap (ribleia atricapilla). This shy woodland minstrel has been termed the "Mock-nightingale," owing to the excellence of his natural song, and his minic powers make him not an unworthy rival of the American Mocking-bird. He is a small bird, hardly larger than a Canary, his color being various shates of gray, except the jet black of the crown, from which he derives his name. The Black-cap is naturally a shy bird, frequenting orchards and gardens, where he obtains his favorite food, and except when feeding he seldom reveals 
himself to the familiar seruting of man. II fool consists of insects of all kinds and the varions wild fruits and berries; he is particularly fond of elder herries, and such fornl in great variety should always be permited him in eonfinement.

Under proper conditions, the Black-aly proves one of the most satisfactury of cage-songsters; few hirds, howerel, require so much attention and care. When eamestly engaged in singing, he sits calmly and gives utterance to notes so sweet and well modulated that even the Nightingale might not be ashaned of them.

Starlasa (Stamme rulgaris). One of the commonest hirls of Europe is the Starling, which is about the size of a small Blatkbipl. He is desiral, le as a cange-bird on atecomnt of his handsome plumage, docile manners, pleasing song, and his aptness to repeat short plorases and to whistle tmes. The plumage of the bird is lark, beantifully grossed hy rapring sharles of green aud purple, pale yellow spots making the end of the feathers.

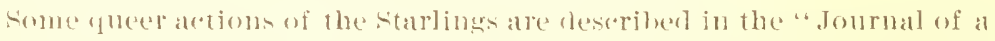
Nattulalist" as folluws: "lhey rastly delight, on a bright alutumnal unorn-

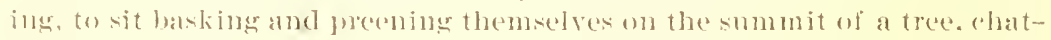
ting all together ina low, song-like note. There is something singularly rorions and mysterious in the eomduct of these hirels previous to their nightly retirement, wy the variety and intrioacy of the evolutions they "xecute at that time. They will form themselves, ferhaps, in a triangle, then shoot into a lowe, peatr-shaped tigure, expand like as sheet, wheel into a ball, as Pliny observes, calch indivilual striving to get into the center, cte., with a jomptitule more like parale movements than the actions of lirds.", 
The Starling is generally insectivorous, but frequently partakes of grain, seeds, and berries; of cherries he is said also to be particularly fond. He takes readily to confinement, and so docile does he become that he may be allowed the liberty of the house, and he will amuse its inmates by the most ludicrous tricks and mimicking misdemeanors. Tunes he whistles almost as cleverly as the Bullfinch, and phrases, often of some length he will learn to repeat. Feed him regularly upon the prepared Mocking-bird food, as recommended for all soft-billed birls, but do not neglect to fumish hin a supply of insects. So bird is less fastidious in his tastes, as he will partake of anything prottered him without grmmhling abont the character of his repast. Bathing he particularly enjoys, taking to water much in the manner of the duck, loving to fuss and splutter, thus wetting everything in the vicinity of the calge.

If it is desired to tealch a Starling to whistle an air, it should be frequently repeated to him daily for two or three months, when he will be able to produce it with aceuracy and finish. A young bird, of course, learns the easiest, sometimes acquiring several tunes which he is able to reproduce perfeetly. 


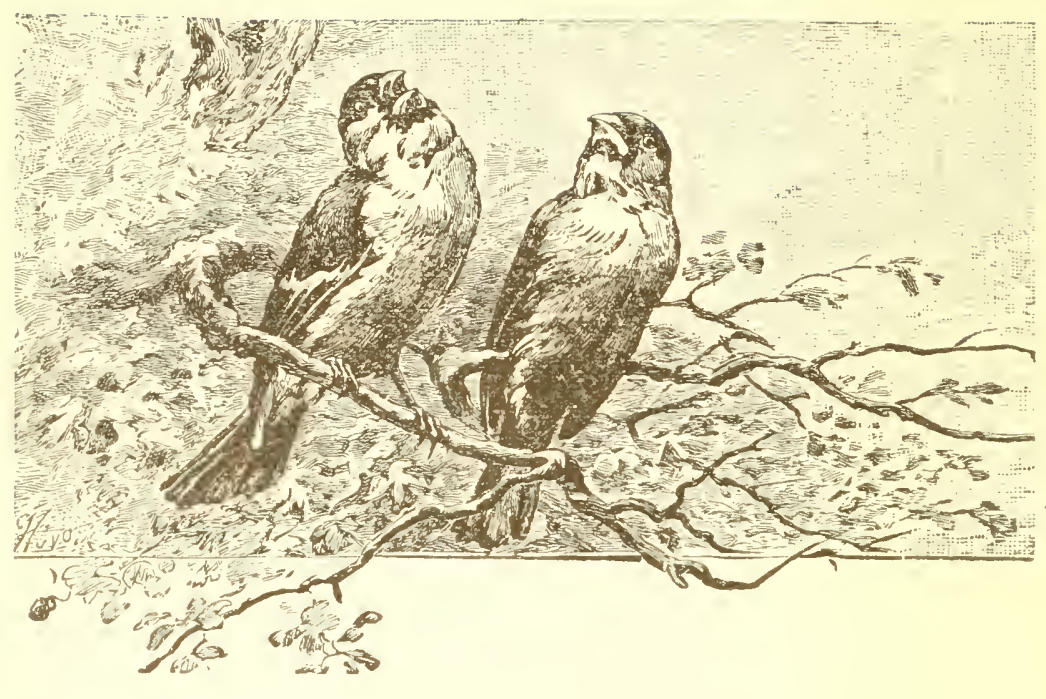

\section{CIIAP'TER TII.}

\section{Ailerican songeters.}

TIIE birks of America are celebrated not only for the variety and excellence of their mu1 sical utterances, but for the beanty of their phunage. No songsters of any portion of the world excel them in either qualification. Birdbreeding and hird-trapping, however, have never been engaged in so extensively in this country as in the Old IVorld, probably owing to the busy pursuits of our countrymen, who have not the time, even should they have the inclination, to care for and train cage-pets. The relative merits of native 
and foreign songsters will probably never be decided satisfactorily, owing partly to national prejudices and partly to the widely liffering characters of song represented. The American Mocking-bird, which is the acknowledged king of native musicians, has not only an attractive song of his own, but possesses minic powers in such a high degree that even the notes of the Nightingale are correctly imitated. But both these birls difter wirlely in style and execution, making a comparison all the more difticult, if not entirely useless. Tery many Ancriean birds might be enumerated which make worthy cage-pets, but owing to the limits of this work only the most prominent songsters will be describerl.

\section{I.-SEed-eating Birds.}

Golnfixcu (Spims tristis). The beantiful plumage of the Sellow-bird, or Wild Canary, his undnlating flight, and agreeable twitter while on the wing, and his frequent visits to city gardens, have made him familiar to every one. His song is pleasing, though not powerful, yet similar in style to the Goldfinch of Europe. He makes his advent in the Northern United States early in the spring, fre. quently in snall flocks, the males of which may often be heard in concert uttering their short, twit- 
tering notes. Many of these songsters are trapped yearly, and few birds are more easily domesticated. They soon learn to love their new homes and their keepers, and show by their affectionate manner their appreciation of all farors. So docile will a Goldtinch become that le may be pernitted to flit ahout the house manifesting no fear of the approach of any of its immates. His ability to perform smart tricks is remarkable: for uncler competent instruction the most diftionlt of trieks are learned in a short time.

The foon of the Gokltinch in eonfinement should be much similar to that of the Camary, with the exception that maw-secd and octasionally a few gratins of hemp may be added to his daily supplies. The male Finch may be mated with the female Canaly, but the progeny is not sufficiently desirable to warrant the trouble. The mating season of this bim is later than that of any other of our native congsters, as it is not until July that the first brood is reared. The nest is usually lined with the down of the thistle, and the seeds of the same plant furnish nutriment to the youmg birds.

Inura Bixtrax (Passerima cyanea). Among the birds that return to their northern homes with the first appearance of congenial spring weather is the Intigo Bunting, and no bird is more welcomed by 
those who love to study and ahmire the feathered tribes in their natural haunts. He is about the size of a German Canary, yet his handsome uniform of blue renders him a conspicuous olject among the half-formed foliage of the trees. This bird is certainly one of the most delightful of our native songsters, his notes being sprightly, cheerful and frequent. The color of the female Indigo is a blue duller than the male's, and intermixed with russet, this being the plumage, also, of the young males. The Indigo is easily trapped, and submits readily to confinement. He will sing most of the year, the principal exception heing during the moulting season. He is a rery desirable bird for the aviary, as his beautiful blue plunage is in marked contrast with the ordinary hues of other songsters. He is a sociable bird, and learns easily many bird tricks, his sprightly musical qualifications rendering him a general favorite. His food should consist of the ordinary canaly and millet mixture, together with a plentiful supply of insects, of which he is very fond. When well cared for he will live from seven to ten year's in confinement.

Nonparen (Passerina ciris). The Nompareil is the name of a handsomely plumaged bird, about the size of the foregoing species, found throughout the Southern States. He is also well known as the 
Painted Bunting, whing to his many bright colors. Great numbersot these pretty somgstersare taken by birl-trapuing nogers of the south tor the Northemo birl-malket. The liph is asily domesticated; in an incerdilly short time he becomes reconciled to his new mammer of life, amb soon learus to aceept flies and other insects from the hand. His regular feed should he almatroest and millet in equal proportions, and heing fond of insects, he should not be denied them. Ho is remalkalyly free from disease, ambl witl plenty of smolime, al daily bath, and a sulply of entarel, he will prove to be a thing of beanty and a joy tor-_ about ten pears.

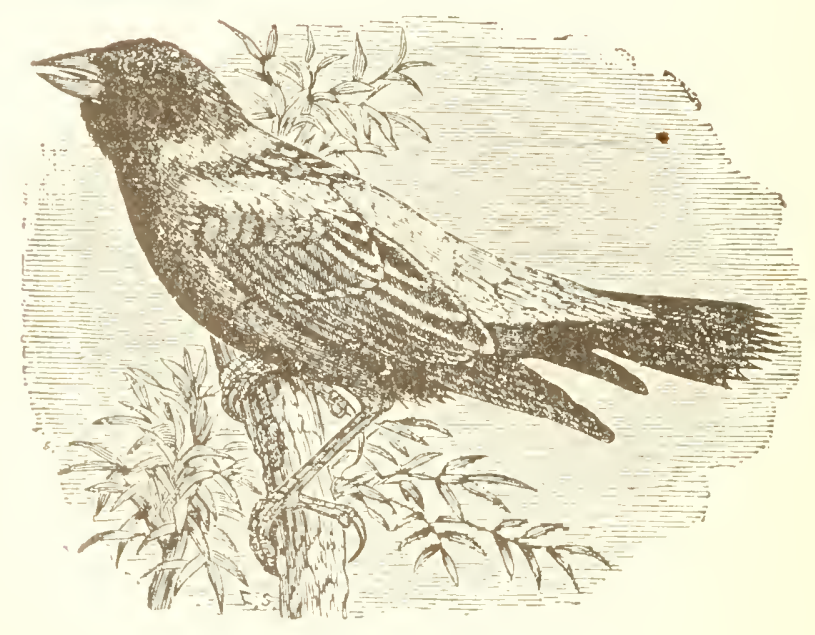

BOBOL.1XK.

Bobolink (Dolichomyer oryzienrus). Nature haspo happier minstrel than the Boloblink. Wateh him 
frolicking with his tellows orer ron dover-blown meadow, and listen to his extatic music as he circles through the air, then say if you have ever known such a personification of mepriment. Like the Skylark, the Bobolink produces his finest songs when on the wnge: but often, frentin amidst the foliage of an apple-tree laden with bloom, his wonderful music hursts forth

As if for a time a hissom latre

Ifarl started to life amol some,

To mount with the wink to the mplee air

And dir while Hoiting alome.

Early May witnesses his adrent in ()hio, but in the New England States he is spoken of as a . June arrival. He is found generally over the Eastem Uniter States, immigrating eary in the season to the South, where he feerls mpon the rice crops of the Southern planter. There great numbers of Bobolinks, better known as the Rice-birds among the planters, are killed and served np presently to tickle the palates of epicules.

During the breeding season the male Bobolink differs essentially from the female. IJe is for the most part black, the hind heal yellowish white; scapulars, rump, and tail-corer's white, tingerl with ash. His length is sevell and one-halt inches.

The Bobolink thrives well in a cage. He is a voracious feecler, and to prevent his growing too 
fat to sing, only the simplest food should be given him. He should not he contined in a small cage, as that would attord him too limited means of exercise, and exereise he neods, and plenty of it. Gravel must be smpplied him, and a daily bath. No dainties ale permissible. Ilis principal seed should be anary and mohmbled rice. and these ought to be given only in limited quantities at at time. The bolwhink is perfertly hardy, living in confinement with forepere cance about as long as any other lipk. On aneoment of his gluttonous habits he is untit for an aviary, at he would le sure not only to over-fred himselt, luit to pol, his tellows of their daily loratil.

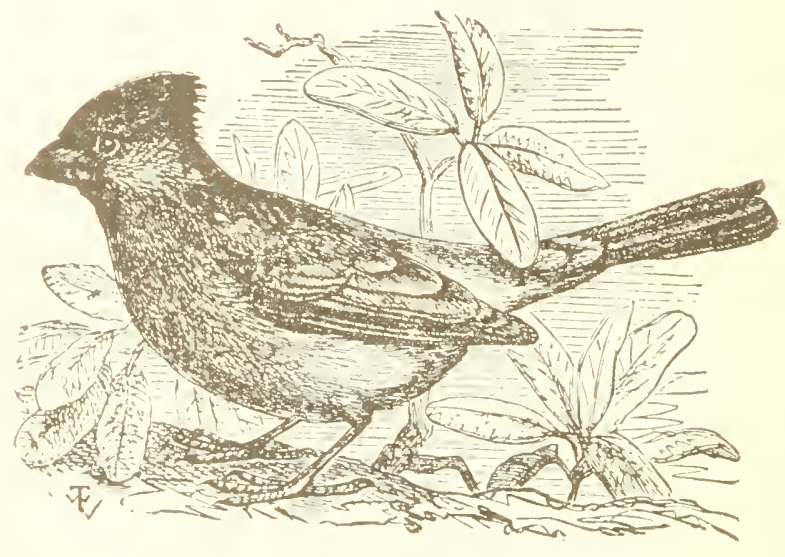

REDbJRI.

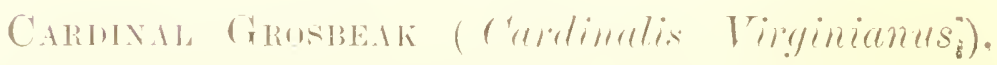
The Redbird, as this (xorsheak is familialy called, 
is too well known to require description. In many homes in this his native country he is a great favorite; in Europre, also, he is admired for his beanty and his sprightly manner. Ilis habitat is the Southern States and the country as far north as Central ()hio and Pennsylvania, being resident wherever found throughout the year. He is easily domesticated, and lives, if properly ared for, many year's in confinement. He locomes greatly attached to the one who attends to lim, manifesting the greatent pleasure upon heing noticed or petted. In his wild state he is very pugnacions, this trait rendering him an casy prey to the snares of the traplper. No somer does his keen eye notice the "call-bird" of his wonld-be possessor" than he makes ar rukh at him, which ton often for the Cardinal proves to he his last, since lee quickly finds himself shut in behind prison-bars, a life prisoner hecause of his desire to fight. But woe to the mulucky hand that at such a time comes within reach of his powerful beak. This he sometimes uses to such good advantage that he often compels his captor to release him in alarm, thus affording him eseape. The Redbird will breed in confinement, but being so quickly taken and so easily domesticated the trouble of breeding is not usually midertaken. The female is preferred by some to the male, as she is considered a good singer, 
hel voice being more nellow and sweet than the male's; the latter possesses a greater variety of notes, besides exeruting them with more spirit.

The Redbirl requires a good-sizerl cage, which should be kept properly deaned. Ile will enjoy a daily hath, and will execute a "song and dance" if treated to a meal-worm occasionally, or for a change, to a little graterl beef. Too much of such food, howerer, will at times prove injuriens. Feenl regularly a mixture of lemp and antaly-seed, together with mhlulled rixe of sunflower-seent. Bits of apple or of boiled potato will be sreatly relished, and a regular smpuly of gravel for the bottom of the age should not he wanting. The discases of the liedbird are few, and, like all birr ailuents, alde due to neglect of sanitary conditions or mowholesome feeding.

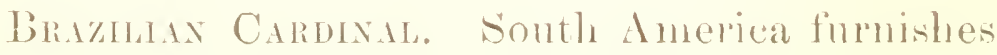
the bird-finciers of the world with the Gray or Brazilian Carlinal, a beautiful, crested songster, much less brilliant than our own Cardinal, but resembling him in general chanderistics. The plumage of this hiod is considerably diversified, the heald, crest and throat being a pronounced scarlet, the buly helow a greyish white, the back dark gray, the wing and tail darker shades of the sime color. This length is about seven inches. 
Although his musical talents are not of the highest rank, his song is melodions, not as lond as the Reulbird's but filled by a degree of sweetness that is quite pleasing to the listener's ear. The transition from the wam atmosphere of the tropies to an abode in the cool temperate zone does not seem to affect the bird adversely; he is rarely fonmd to be sick. His food is mululled rice and canary-seed, a few meal-worms or insects being ted him oecasionally. Water must be finruished him daily for bathing purposes, and plenty of glavel. Mis habits are repy similar to those of the Reclhird, and his general treatment need not differ from that of the latter species.

Rose-Breasted Grosbear (Hubia ludoricinia). The habitat of this heautiful songster is the Eastern United States north to Southern Canada. It cannot be said to be altogether lare, but owing to its secluding habits it is sellom seen by casual observers. Deep' woorlland and secluded river banks are its favorite abodes, and there, nuobserved by curious man, its wonderful song is produced.

The Grosbeak is one of the showiest of songsters, and respecting animation, his musical qualifications are said to surpass even those of the Mocking-bird. Althongh a desirable bird for the cage, the Grosheak is seldom met with in contine- 
ment. He is a voracions feerler, and like the Bobolink, frequently tills himself to satiety. To this cause his diseases, which ale few, are principally due. Too much food, therefore, should not le given him at one time. Canary-seed, muhulled rice and hemprseed may he ferl for a regular diet, and ocensionally some Mocking-lind food, a mealworm. or ripe fruit, may he adled to his usual fare. He enjoys hathing, and will continue to use the hathing-water as long as it remains in the cage. It is better to withllaw it as soon as he has undergone one thorough ablution.

\section{II.—SUFT-BHLED BHRD.}

Mockina-biab (Mimus Polyglottms). The Mocking-bier is a fatragon in the mosical world. In addition to his well-known powel's of minnicry, his voice possessess an expluisite sweetness, while his spurighty and grateeful torm and intelligent manner fill the ohserver with almiration. Ite belongs to the great tamily of 'Thrushes. all of which are remarkable for theip rolubility and mimic powers. The home of the Mocking-linel is in the south Atlantirand Gulf States, whepe he hreeds in great numbers. He is migratopy as far north as Olio and l'ennsylvania, hut his ocenrence is rare nopth of the Ohio River. The female is remarkably like 
the male in phumage, and in some instances, probably rare, has proved that she is not always an unworthy songster. She sometimes possesses the distinctive wing-markings of the male, so that even an expert fails to determine the sex of young birds correctly.

"lo examine the wing of the Incking-birt, to distinguish the sex, catch the bird firnly in the lelt hand, and extend either wing to the fullest extent with the right, Inoking at the wing on the upper side; the white coloring will be observer to be longest on the feathers nearent the tij, of the wing; the extent of white anloring waulually diminishes on the feathers nearest the body, and in the anse of the perfert-marker male hird resembles somewhat the segurent of a circle, and in some lombities has recoived the name of half-moon. The three longer primaries which have the white color will be foumd to have no lark markings, or splashings intremixed with the white. If the white markings are splasherl or lo not extend directly across the foathers, the hirr may be a fermale. In rarecalses, four of the feathers are ummistakably malked with clear white, and these are consirlered jerfert-markerl birks, and rewguizerl as males to a certainty. The bircts which have two feathers and a half reas, the two longer whitecolored feathers preffert and a splakh or darli mark, on the white om ome

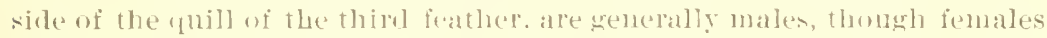
are sometimes so matien. The white color om the feathers wi the female bird will be fomml to les - plathed and irregularly marked thronghout." Holden.

The Mocking-bird will breed in confinement, and the young are less shy than the captured birds on aceount of long domestication. In the south the young birds are taken fiom the nest when they are three weeksold. and fod by hand by their negro captors. Traps are set for those that hare escaped captne in the nest. The hirks are rearly for the market in June, and may be supplied during the remainder of the summer. The full musical powers of the Mocking-bird are not developed during 
the first year ; indeed, it is not until the third year that he reaches the eminence of perfection. IIe should then be a prime musician. This bird is remarkably haldy, and with proper are will live to delight his owner for some twenty or more years. His requirements are not many, but they should

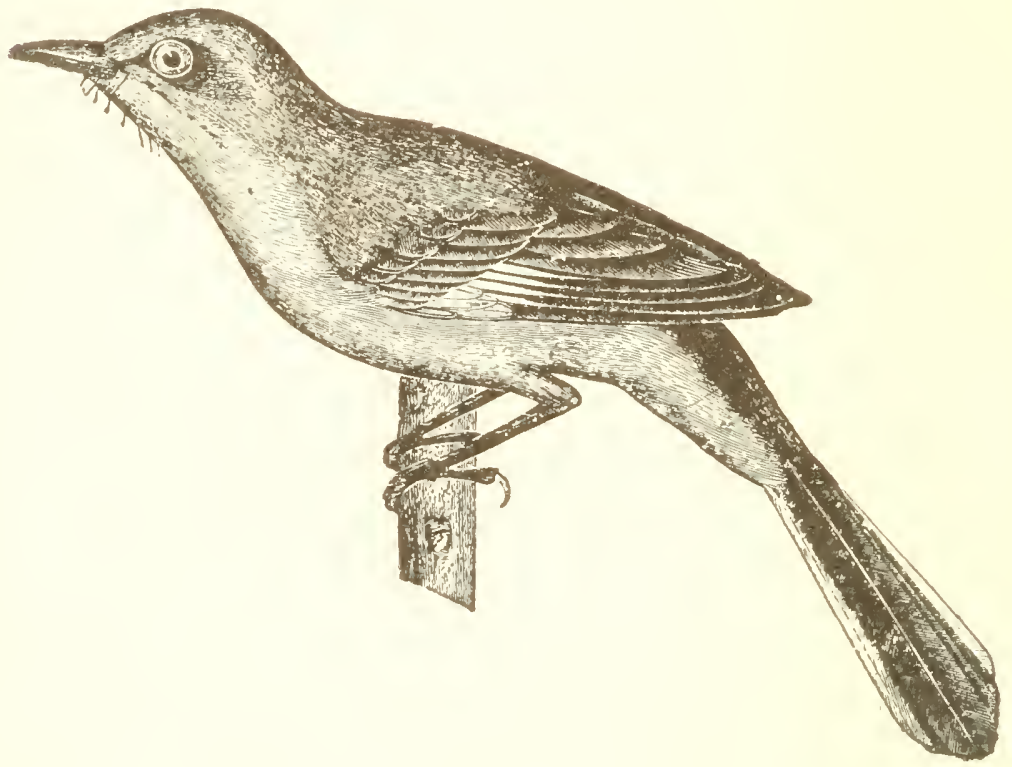

MOCKING-HIRI).

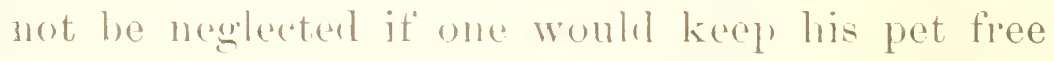
from discase. A latree roomy cage should be his somicile, kept scrupulously clean and fiee from dranght, a plentiful smply of gravel being kept in the drawer. The bind should have a hath daily, and a sufliciency of fiesh hrinking water at all 
times. He is a roracious eater, lut this is natural, as he is a busy fellow, and busy fellows nust have good food and plenty of it.

Most of the diseases to which the Mocking-bird is subject result from improper diet; care should be taken, therefore, not to neglect to feel the bird wholesomely, and not to permit his drinking water to become stale. Feed daily the prepared Mocking-bird food mixed with grated raw carrot. For variety, there may be fed occasionally a mixture of hard-boiled egg and potato in the proportion of two parts of potato to one of egg. Ripe truits and berries are much relished by the bird, and are beneficial. Soaked ants" eggs, which may be obtained from dealers, meal-worms, inserts and spiders form a very rich and nourishing addition to the diet. These are alwars welcomed hr the bird, but they should not be given too often.

As has been said ahore. the diseases of the Mocking-bird, as well as those of caged songters in general, are due to neglect. Prevention of such troubles will be found to be always better than a cure. Constipation may be relieved by feerling plenty of fresh green stuft, insects and meal-worms for a few days. If this does not attord relief, give a few drops of castor oil. Diarrhora, which is generally caused by foul drinking water or stale food, yields to a change of diet, for a short period, to 
crusts of bread soaked in boiled milk, and a scanty supply of insects and other dainties during the continuance of the tronble. The pip is an annoying and dangerous trouble, usually caused by taking cold. If your birk does not sing and refuses to feed as usual, atch him and examine his tongue. There may be found on it a horny scale, which must be removed with sreat care. Commence at the base of the tongue, and by means of a blunt knife or tinger-nail, peel oft the scale towards the tip of the tongue. A few drops of glycerine then placerl on the tongue will serve to heal it.

Brown Thrasher (Harporlymelus mufus). In the Northern States the Brown Thrush, or Thraher as it is allerl, is a wortlyy rival of the Southern Mocking-hird. The powers of mimiery of this bird are certainly remarkable. P'erehed on a high branch of a tree, he nay often he heard uttering his mellow callences, making his notes resound for a long distance. In color he is attractive as well as in song. Ilis back and tail are of a reddishbrown, his under parts white, the breast being thickly spotted with black. The colors of the female are somewhat duller, and the spots fewer and less distinct upon the breast. The Thrasher has arrived in his northem abodes early in May; thick underbrush is his favorite resort. While not 
so shy as some species of his family, he is nevertheless not anxions for olservation, and whisks away into the brush whenerer any intruder npon his solitude presents himself. He may be distinguished from the Wood Thrush, which he much resembles, by his great leugth, that being not less than eleven inches, while that of the Wood Thrush does not exceed eight. Like the Robin, his favolite hours for singing are the early morning, when the rays of the coming king of day are wreathing the forest tops, and the evening, when the setting luminary is laying his rosy finger's in benediction upon the woodland monarchs. This Thrnsh is seldom seen cager. Why this should he so it is not easy to see, as few birls certainly present greater attractions, and few, if any, can excel the Thrasher in intelligence. The best birds for the cage are those taken from the nest and fed by hand until large enongh to attend to their own wants. The nest is usually found in a heap of underbrush, the young being four to six in number. The habits of the Thrasher are similar to those of the Mocking-bird, and his treatment differs in no way from that of the latter species. The largest-sized Mocking-bird cage should be selected for him.

Wood Thrush (Thedus mustilinus). This Thrush is known to every student of bird-life as one of the 
sweetest of woolland minstrels. Naturally shy, lie is to he foum omly in thickly woorled places, whele his sweet rojee is sure to he heard even if his form remains moseen. In apleatrance he is much like the precoling species, his length hejug between seven and cight inclies. II possesses fine natural lowers of sollg, in adrlibion to which lie is an acomplished minic. Morning and evening are his favorite periods for singing, yet frequently throngh the day his roice may be heard ringing throngh the wombland. When raged, the Wood Thrush shombl he siven the same treatment as the Mocking.hime, and a small-sized Mocking-bird cage is best allapted for him.

Cat-Bune (Gulcoscoptexamblimmis). Every risitor to the rountry heeomes arguainted with the darkllumaged, gamplous Cat-limel, who inquisitively introdnces himself, time atter time, with his quaint mem? Any lomd or monsmal noise, instrat of driving lim farther away, bring him nearer, like an inquisitive busy-boly who walnts "to know, you know," all alonut the matter. Evely school-boy knows him and throatens lum erery tamel despises him and molests him. Ho is very foud of the farmer's cherries, and is not averse to taking a hee now and then: so his life must be forfeited quite often for such mislemeanols. But it the 
farmer would panse to cousider that the Cat-bird, and some other birds as well, devonrs many insect pests during the year that would otherwise destroy more fruit than many birds could possibly consume, he might learn to regard this innocent and sociable bird as one of his best fipends.

The Cat-hird is a very good songster, his notes resembling those of the Thrushes previously described, and althomgh seldom seen caged, few birds prove more satisfactory as cage-pets. Whether in his wilk or domesticated state, he never exhibits fear on any account, secming perfectly trustful in the good intentions of all eomers. The regular Mocking-birl rage is best arlapted for him. His food should be the regular mixtmre, fed with grated raw carpot, 11 addition to which give plenty of insects and occasionally some bits of raw beef: Plenty of fresh ripe finit is also essential, berries in their season heing particnlarly relished.

Scarlet Tanager (Piranga erythomelas). The most gorgeous songster of our contment is without doubt the Scarlet Tanager. If his song is given an inferior rank, his beauty cannot he called in question. His size is about that of the Woor Thrush, his colors scarlet and black, the wings and tail being of the latter. The female is a clear olive-green, below clear greenish-yellow, wings and 
tail dusky, elgert with olive. The colors of the male undergo a transformation in the fall, becoming much like those of the female. This bird may be frequently seen in sunlit woodland and along the banks of streams during the early prart of May, but soon after he retires with his mate to unfrequented woods to breed. His ordinary note is a sharp" "huck," easily distinguished from the utterances of other lirds. Ilis song, which is heard more frequently during the brecding season, consists in a succession of warblings similar to a Robins, wholly unpretentions but not unpleasing. "His song is given," says a writer, "atter the manner of a ventriloquist: for althongh he may be at a considerable rlistance from you, the notes appear as though coming from a point directly above. This is, no doubt, a power bestowed on him as a protection from the langer to which his lorilliant colors expose him."

The Tanager should he confined in the regular sized Mocking-bird cage, and fed the prepared food in the usual manner. Ripe firuts, figs, and dried curants after being moistened with water, may be supplied abundantly; ants' eggs and meal-worms are always relished and beneficial. Highly plumaged birds liave usually tender skins, and are very susceptible to changes in temperature; it should be seen to, therefore, that a sufficient warmth, par- 
ticularly in winter, is maintained where the Tanager's cage is hung. With a good supply of food in variety, and a proper attention to hygienic conditions, there is little reason why the Tanager can not be kept as long as other birds.

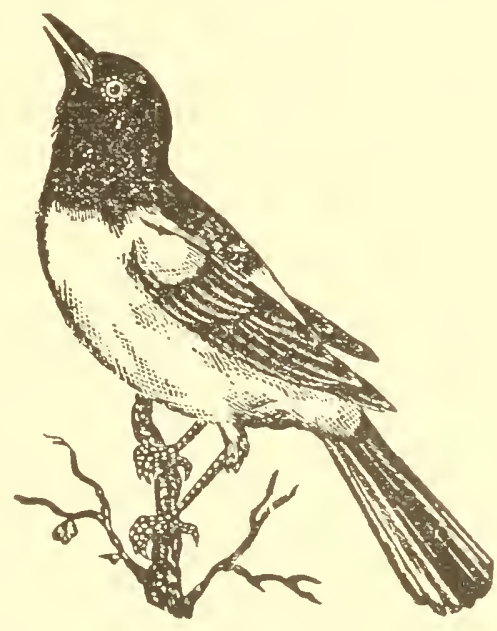

BALTIMORE ORIOLE.

Baltimore Oriole (Icterus galbula). In point of beauty the Scarlet Tanager is not far in advance of the Oriole, or Golden Robin as it is sometimes called, certainly one of the most interesting birds of our American fauna. The lively whistle of this bird as he flits from branch to branch of sunlit trees in search of dainty morsels, is sure to please the ear, while his dainty form delights the eye. The latter part of April witnesses his advent, and 
from that time throughont the summer he is to be met with along the borders of streams and in open woodland. The nest of the Oriole is hung from the end of the branch of a tree, often at a considerable height and usually over water. The young are therefore difficult to take, although occasionally an opportunity might be given to acquire them. The colors of the Oriole are black and orange; the head, throat, wings and mildle feathers of the tail are of the former color, the lower part of the back, breast and under parts being of the latter. The colors of the female are dull and mattractive. The song of the Oriole eomsists of a few whistled notes frequently repeated as he flits alistractedly among the green foliage of the trees. He feeds upon the tender buds and 11 jon a rariety of insects that he finds infesting the branches. IFis food in continenent should be the Mocking-lird mixture and the usual smply of meal-worms, ants' eggs, and, in fact, almost all varieties of caterpillars, bugs and beetles. These are essential to his welfare, as they form his principal tood in his wild state, and if not supplied with them regularly, he is apt to languish and die.

Orchard Oriole (literus spurins), is a near relative of the Baltimore, and likewise an excellent songster. His colors are black and chestnut when 
his plumage is perfect. His habits are similar to those of the preceding species, and $l$ is food and treatment in confinement are likewise the same.

Troopial (Cassicus icteronolus). South America furnishes bird-lovers with the handsome Troopial, which reminds one of our Baltimore Oriole, although the size of the former much exceeds that of the latter. The head and throat, the wings, and a portion of the tail are black, while the body is orange. The Troopial is easily domesticated when taken from his forest home, and soon becomes a great favorite with his owner. His food consists principally of fruit, insects, and dainties of all sorts, as lie is a gluttonous feeder, his fonduess for rich food being frequently a cause for future ailments. The feeding of the Troopial should be much like that of the Mocking-bird, the prepared food being furnished him daily, mixed with grated carrot. Ripe tropical fruit, such as bananas and oranges, and occasionally spiders and meal-worms, should be given in variety. A large-sized Mocking-bird's cage is the best for him, but he soon learns to make himself at lome if permitted the freedom of the house. Bathing being a favorite ocenpation with the Troopial, a plentiful supply of water should be furnished daily for that purpose. He is subject to few diseases if properly cared for, 
and will live for many years in continement. The natural song of this bird is rich and mellow; although his notes are not many, they are quite agreeable. He has a retentive memory, and soon learns to repeat a tune whistled or played to him on a flute or other instrument.

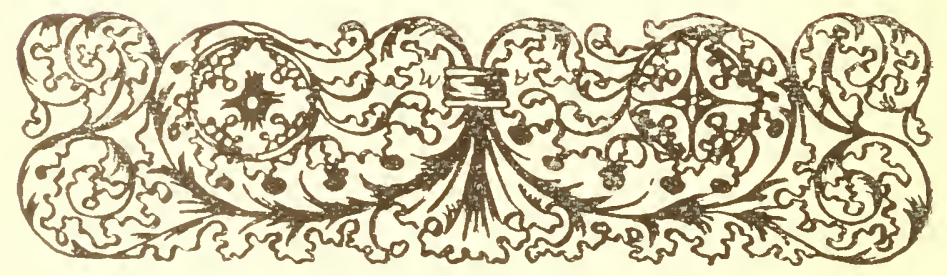




\section{CIIAP'TER VIII.}

\section{Talking Pets.}

THE well-known ability of many birds to initate the sounds of the human volce has

1 made such for all time a farorite class of houselold pets. Some possess this power in a very high degree, while others are capable of having a few words only fastened upon their abstruse brains.

Two distinct classes of birds manifest the power of articulation with more or less intelligence, viz.: the Psittacidac or Parrot family, and the Corvidae, to which may be added the Sturnidae or Starlings, some of which are quite capable of instruction. The first-named family comprises the Parrots and Paroquets, Cockatoos, Macaws and Lories; to the second belong the Crows, Ravens, Rooks, Magpies and Jackdaws. The conmon Starling of Europe and the Talking Minor of Asia, which is classed as a species of Sturuidae, often prove themselves quite proficient in a conversational way.

\section{I.-PsitTacidae.}

Parrots and Paroquets. No birds are generally recognized as so apt to reproduce the sounds of the human voice as the Parrots, a genus that comprises 
many species inlubiting various parts of the globe. 'The favorite habitat of the true Parots is the luxnriant regions of the torrid zone, hut some species are to be met with tully forty-five degrees of latitude from the equator, both north and sonth. lhey are known to be long-lived birds, usually moving in flocks, and feeding upon the seeds and finits of tropical plants. When taken young the T'areot submits readily to confinement, and sonn becones

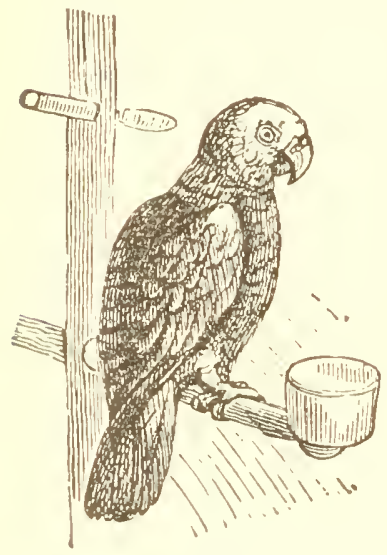

PARTI' a spoiled peet of the household. Great numbers ot these birds are captured during the breeding season ly the native hirellunters, and shipped to the valions conntries in which there exists a lemand for them. They reach our market in the early fall when the birls are some five or six months old, and are sold at piees varying in aceordance with kind and intelligence. The difficulty of distinguishing male firom female Parrots is very great; both birds are the same in size and colomtion, and are equally capable of being tatught, so that only an expert can apploach to any knowledge in this regard. It is possil)ly on this account that every Parrot is called "Polly," hut why "Polly" should 
always "want a cracker" is not so casily explained. Parrots are seldom bred in confinement, yet there is $n o$ reason to doulut that breeding could be successfully accomplished if proper arrangements were made for the purpose. In their native state they form nesting settlements in some inacessible places, and make their nests in holes in trees, excavated, possibly, by friendly Wodpeckers or by the females themselves. The parent birds are strongly attached to their young, and will fight lustily for their protection.

Parrots learn to speals just what they are accustomed to hear, and their memory in recalling words heard possibly months before they are repeated, is truly remarkable. After being placed under instruction, from four to twelve months usually elapse before a birl essalys to talk. It takes a long time, it seems, for the lird to make mp his mind to venture upon such a remarkable career as that of an orator, but when he once does so he adds to his vocabulary almost daily some new and startling expression. The stories told of Parrots are no donbt often exaggerated, hut instances are authentically vouched for in which these birds have made use of expressions with little less than a human understanding of their significance.

A lady once owned a Parrot that was very fond of pickles, and no opportunity was lost by it to 
pilfer them if they could not he otherwise obtained. For such misdemeanors he was scolded and whipped time after time, but still his evil propensities continued. One day, being caught by the cook in the very act of abstractmg his favorite morsel from the pickle-dish, that highly irate person threw at poor I'olly a pailful of scalding water. Incensed at such shabby treatment, the Parrot sulkily refused to be petted or to have anything to say. To make matters worse, all the feathers on the head dropped off, until Polly was decidedly bald. Several months elapsed, and the lady thought that the bird lad ceased to speak forever. One day the new elergyman called at the house, and upon removing his hat, disclosed a very bald head. At once the Parrot strode from his corner, eyeing the newcomer with evident curiosity, then, to the astonishment of all, lurst into a loud laugh and exclaimed: "Oh, you"e been stouling pickles, too!"

The amount of instruction that some Parrots are capable of receiving is almost without limit. Very much, however, depends upon the trainer's ability to instruct, and not all persons are suited for this employment any more than all are suited to become teachers of children. The voice of the trainer should be pleasant, but clear and ringing, and his manner gentle. If the bird under instruction does not learn in a week or a month, or six 
months or a year, the patience of the trainer must still be inexhaustible. Parrots have been known to remain mute for many months in apparent stupidity, then suddenly, to the surprise of all, enter upon a remarkable career of loquacity. Gentleness, by all means, should characterize the trainer's methods. When the bird sees no harm is intended it, and that it need not be on the outlonk continually for an expected cuff, its confidence will be established, and it will acknowledge its keeper with an affectionate regard.

It is best to cage or chain a Parrot, for when allowed the freedom of the house food is apt to be found that is unwholesome; besides, Parrots make better talkers when kept behind the wires of a cage, most of the time at least. The usual size of cage is one about fifteen inches in diameter and two feet in height. A plentiful supply of clean gravel should be fumished, both for eating and bathing, as this class of birds cleanse their skins in the sand rather than by water. The cage should be kept scrupulously clean, receiving a thorough ablution with soap and water every few days. Although Parrots do not bathe in water, it will be found best, at least once a week, and oftener in warm weather, to surinkle over your bird a quantity of soft water slightly heated, in which may have been dissolved a thimbleful of borax. 
A sulstantial diet of wholesome grains is best for this class of birks: withlogld dainties from the tahle and rich, oily nuts, greasy animal food and the like. Feed your own l'arrot if you would have him to live the tull time of a Parrot's life. The proper seed mixture is composed of equal palts of mulunlled rice. hemp. sunflower-seed and crusherl copn. and occasionally a few peanuts may be given. Ripe fruit in moderation is beneficial, as are also bits of mealy potato, a crust, or pieces of diy toant, and there is no objection to administering a "craker" if ". P'olly "really "wants" it. But let it he strietly seen to that the bird is not given meat, butter or grease of any kind, as such food will always work mischief. P'arrots nse hut little water, but they should always have access to fresh drinking water if they want it. Sometimes cottee is substituted for water; this is beneficial in some asere, hut some birds will be found that do not like it, and prefer fresh water. Some bread soaked in milk, and strinkled with a little sugar, may be given once a day, but this should be remored when the hird has had all it resires. Young birds shonld be given liquids sparingly until thoronghly acelimated. Enongh moisture can be obtained from the prepared foods that are furnished them. Creen Parrots are particularly subject to disease trom over-drinking. Bread soaked in 
water, and squeezed lightly before feeding, is good for them, but sometimes the bread when soaked in cottee is better relished. Tou may give your birt a drink once a day, holding the cup in your hand, and not permitting too great an indulgence. After a time, if no bowel trouble alpears, water may be similarly furnished twice a day, and finally, when the bird can be considered fully acclimated, fresh water may be placed in the cage, from which the bird can drink at his pleasure. Young Parrots cannot eat the hard seeds recommended for adult birds. A good food is prepared by pouring boiling water over rice and leaving it on the fire for ten minutes. Place in a collander, and after boiling water is drained oft, pour orer the rice a, quantity of cold water, thus washing off the starchy matter on the surface of the food, which would eause some of the food to adhere to the bird's beak. Hardboiled egg, mixed with bread moistened in water, is good, nourishing food. All such preparations readily become sour, especially in warm weather, and should always be removed when the hird has eaten all he desires.

Parrots are subject to some diseases which alre mostly due to improper feeding. Judging from the number of these birds that find their way into the hands of the taxidermist, we may be sure that a good per cent. of them do not live the allotter 
years of Parrot-lite. Like the ailments, however, of other cage-pets recited clsewhere at some length, the troubles to which Parrots are subject arise from neglect or the feeding of injurious substances. If it is noticed that a bird is plucking ont its own feathers, it is certain that the blood of the bird is in an inflamed condition from over-feeding, or the use of greasy food or meat of some kind. Cease feeding such substances at once. It is sometimes the case, however, that the plucking of feathers is induced by the presence of parasites upon the bird's body. The eage shondd be thoroughly inspected, and if any signs of lice be found, let a thorough cleansing be at once given. Catch the bird and dust it with German insect powder under the wings, and around the neck and head in particular.

For costiveness a bread-and-milk diet may be given, and plenty of fresh fruit fed for a few days. If this is not sufficient, a few drops of castor-oil dropper into the bird's throat will nsually give relief. Diarrhea is caused by sudden changes in diet or the feeding of stale food. A few drops of paregoric may be effectually given, and the drinking water should contain some rusty iron. In all ailments return to a hygienic diet, keep the bird clean and warm, and nature will do the rest with her healing balm. 


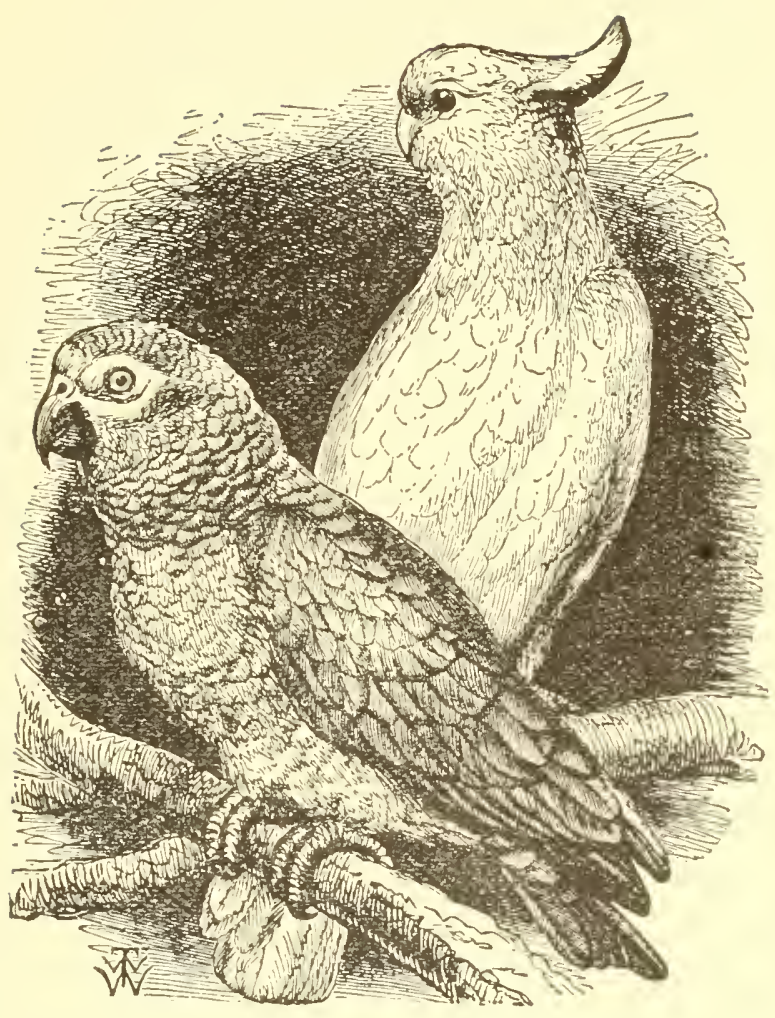

(IRAY PARROT AND COCKATOO.

The Gray Parrot (Psittucus erithurus) ranks at the head of all talking lirds. His speech is remarkable for its volubility and the distinctness of articulation. The home of this bird is on the western coast of Africa, whence he is brought by captains of trading vessels, who obtain supplies of birds from negro captors. During the first year the bird is very dark in color, but at the age of two years he has adorned himself in his modest coat of 
gray and sorrlet, the body being of the former color and the whole tail of the latter. The Gray Parrot is probably the longest-lived of any of the family, some authors aftiming a knowledge of birds at least one hundred years of age. He is an expert talker, ean often whistle a tune accurately, and in some instances las learned to sing popular songs.

The Mexican Dolble Yellow-mead Parrot ranks next in faror to the Gray, and is the leader of the numerous tribes of green Parrots found the world over. Some lovers of birds, indeed, prefer the Mexican to all other Parrots, not excepting the Gray, the voice of the former being characterized by more softness and calence. Tle is the best singer of his tribe, often being ahle to sing through several songs with finish and operatic accuracy. 'This Parrot is seldom trapled, but is taken from the nest and reared by hand; consequently there is not the natural wildness to overcome in submitting the birl to domestication. Naturally he learns more quickly on this account.

The size of the Nexican Parrot is somewhat greater than that of the Gray, his length being about fifteen inches; his color is a beautitul green, red and blue feathers aplearing in the wings and tail; the forehead is characterized by pale orange, 
which, as the bird grows older, extends backward over the head, thus giving him his name.

Next in rank to the preceding species is the Amazon Parrot (Psittacus Amazomius), a bird of great beanty and withal an excellent talker. The length of this bird is about fourteen inches, his color bright green with the feathers marked by dusky or blackish margins; there is a bright red patch on the wings, ustally bounded by sharles of blue, green and yellow, which colors are only conpletely risible in the expanderl state of the wings; the tail feathers are green, but appear red beneath the base when expanded. A bright blue band reaches from eye to eye, beyond which the feathers of the crown, cheeks and throat are of a jonquil yellow; the legs and feet are either dusky or of a pale grayish brown. The Amazon Parrot displays considerable intelligence, learning to whistle and sing quite acceptably; his rank, howerer, is decirledly inferior to that of both the Gray and Mexican Parrots.

The Single Yellow-head Parrot is some twelve inches in length, and nearly resembles the Mexican Parrot in color, the yellow of the head being confined to the forehead, hence the name in clistinction from that of the Double Yellow-head. This bird 
does not command the price of the Mexican, his capacity for learning to talk being of an inferior order to that of all preceding species.

The l'alloot most nuet with in the markets of the comntry is the Cubsx, a small hut interesting speries fomnd ahmonaty in the West Indies, and taken from the nest before being tully fledged. Cuban I'arrots are inported into the United States in large numbers when from three to five months old, and owing to their cheapmess and general docility, usually find reaty purclasers. In intelligence the Cuban is abont equal to the Amazon Parrot, and even surpasses that birl in his ability to talk, taking, also, a foremost rank as a singer. He is quite harly, very tame, and possesser a beautiful green plumage. All things considered, he is one of the most desirable pets of his kind, the price at which he is sold in our markets placing him within the reach of those birl-lovers whose conditions in life make impossible the possession of high-priced Parrots.

Equally desirable as a cage-pet is the DWARF PArrot, which is found flentifully in South America, a diminutive species of the Parrot tribe, differing in no essential varticular from the foregoing varieties except in size. The prevailing 
color of this Parrot is green, slightly modified into lighter shades on the throat and under parts. Tis length is about seren inches. This birt shows extreme docility, and takes a front rank anong household pets. He learns to speak in a small, flute-like voice, performs amusing tricks, and lisplays the utmost affection for his keeper. When kept with a mate, as is frequently the case, he showers upon her all the derotion of a loving heart. He seems born to caress and be carcssed. When separated from his mate the affection displayed for her is given to any who befriend and pet him. The freedon of the house may be permitted him, as he destroys nothing and does not seek to gain his liberty. The Dwarf Parrot ilelights to bathe in water, wulike all others of his lace. His food consists of fruits and seeds, the best seed for him being canary and hemp. Sweet apple, bits of hanana, and the like, are much relished, and necessary for the maintenance of health.

The Dwarf Parrot is sometimes confounded with the Paroquets, a numerous class of birds belonging to the great family of Psittacidae. Asia and Australia are the homes of these diminutive and beautiful birds, those from the latter country being more frequently imported. The body of the Australian Paroquet is hardly larger than a Canary's, 
but the tail being long and graceful makes the extreme length of the hird from nine to ten inches. Paroquets do not learn to talk, and, indeed, are very difficult to train. Being kept in pairs, they seem perfectly unconscious of everything save their own existence; and so fond are the birds of each other that if sepratated they will often mope and die.

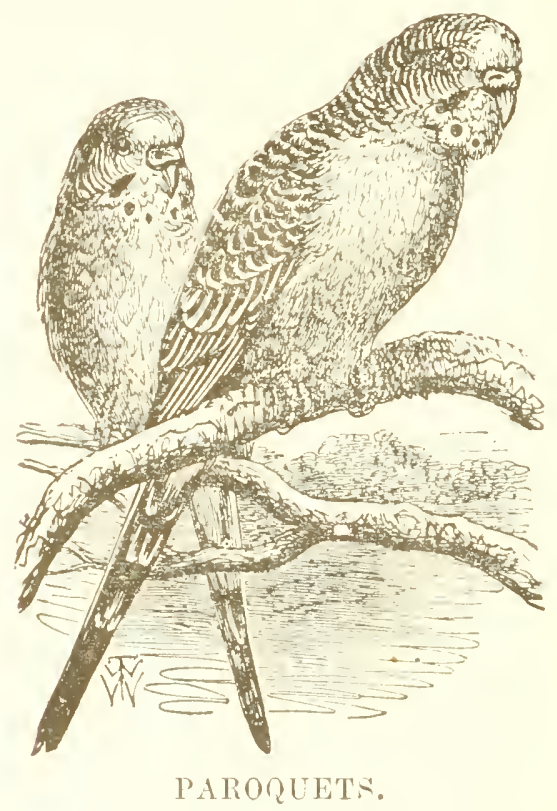

When once properly acelinated Paroquets are hardy birds, withstanding great extremes of heat and cold. Canary-seed is the food most essential for them; to this may be added a quantity of millet. Dainties are not relished as usual with most 
birds. On account of their affectionate disposition the term "Love-birds" has been generally applied to all Paroquets, but this name properly belongs to a species derived from Africa. This may be distinguished from the Australian Green Paroquet by having a bright orange color on the head, the general color of the body being green, while spots of orange and black characterize the tail. The length of this species is about six inches. All Paroquets make excellent aviary additions, and as attractions for the sick room, cannot be excelled.

MACAW. This large and beantiful species of Psittacidae is well known to all lovers of birds. He is easily tamed and soon learns to talk, and if one can withstand his squawk, which explodes at times with dynamitic force, he may become a farorite pet. When hungry he does not hesitate in the least to let one know that it is a "long time between drinks" or meals, and does it so foreibly that if any peace is desired one must accede to his desires. He possesses a powerful beak, with which he is equally capable of demolishing a favorite piece of furniture or of making any intruding hand feel as though it had been struck by a buzzsaw. The bird lives to a very old age, an instance being on record of one that lived in a royal family for one hundred and fifty years. 
Soveral varieties of Macaws are well known to dealers. One of the laryest as well as the most splendilfis the Scarlet Macar (Mucrocercus macao), the prominent colors of which are scarlet on the hear, neek, breast, belly, thighs, upper part of the back, and lesser covert feathers of the wings, and blue, yellow and green on the remaining parts of the wings, back and tail. The Blue and Teldow MAciw (Muerocereus arurame) is less common that the scarlet, but about equal in size. The Grees MaCAW (Macrocereus severus) exists in great flocks, which are very lestructive to coftee plantations.

Cages are selfom used tor these birds, but when they are employed they should be quite commodious and very strong. An iron T stand set on a cirenlar zine lase is more appropriate; the base should be kept covered with clean sand. The food of the Macar is very similar to that fumished for Parrots, although more latitude may be permitted on account of the hardy character of the bird and his lusty demands for food which are not to be resisted. He thrives well on hread and milk, nuts, corn and fruits. Greasy fool and sweetmeats are wholly out of place in the hirl's menn, and if permitted will produce a skin discase which canses the bied to pick his own feathers, and thus ruin forever lis heautiful plumage. Give the bird a bath, if in summer, ly boldly showering him ; in winter, when 
mole care is necussaly to prevent colchess, use lukewarm water, and keep the bird in a warm place to lly.

Cockatoos. Fully as interesting and possibly more beautiful are the white and delicately tinted Cockatoos, whose mative lome is in the forests of Australia and the surrounding islands. These become very good talkers when properly domesticated, and are capable of learuing some interesting tricks. Their treatment is similar to that of Par'rots, stands being preferred to a cage for contining the birds. The most remarkable feature about the birls is their beantiful crests, which they raise and lower at will. They are excecrlingly tiendly. to their daily acpuaintances, but sly ot strangers.

Lormes are an interesting branch of the Parrot family that suldom, howerer. learn to talk. They are prized for their beanty and tor their way and sprightly namner, even in captivity. All of these birds ale rely handsome in alplearance, their plumage being sott and downy. They get their nanle, it is said, from trequently repeating the wor"d "Thoro"; in like manner the Cockatoo is named from his natural utterance. The fool and care of the Lory is similar to that prescribed tor all Pallots. 


\section{II.-CORIDAE.}

One of the most remankable of the families of himels is that of the Comidue or Crows. The species embraced in this division are quite numerous, and are found in all parts of the world. Black is their charateristic color, hut many present heantiful valiations in plumage that are highly pleasing to the cye. I most remarkalle feature of this family is the fact that many of the stecien are caplable of learning to seak with great distinctuess and acenlatey; thus the most sifted members of the family have herome ereat farorites in the household. In aldition to their wall-known talking proticiencies, they are capable of prepforming many amusing tricks, by which their values are consilerably inereancel. The birds of this elass, however, are natural-born thieves, and will firepuently comvey valuable articles to certain hidlen nooks, where, perhats. they may remain moliseovered for a long time. The Magple is particulariy proficient in the art of pilfering, and many an article from a lady's bomdoir has been given ule as forever lost, when some fortunate moment reveals it deposited in her Magepess treasure-care. The most prominent bircls of this family are the liaven, liook, Magpie, Jackdaw and crow. 
Ravex (Coreus corax). This is a bird of beautiful symmetry, glossy plumage and stately demeanor. He is widely distributed, and is the largest of lis class in most parts of the world. In color he is a deep black, with varying shades of purple and green. The great brealth of his tongue rentlers him able to pronounce words easily. and these lie sometimes learns in variety. In times of superstition the Raven was ranked among birds of ill-omen, and even the very modulations of his vojece ware studied and noted in order to muderstand the direful ealanity that was presently to affect mankind. He shares very well the ill-repute of the owl and the bat. Says sicott:

"Birds of ill-rmen, dark and foul, Night-'Town, Raven, Bat and Owl."

As the dars of darkness pass aray, and men learn to regard all natural objects in their proper light, the absurdity of such superstitions becomes apparent. Tre can then armire the once lated and despised bird for his natural beanty and his intelligent demeanor. As a domestic bird the Raven camnot fail to anuse and please. The is active, everlastingly lrying into everything that attracts his attention, pilfers and conceals whaterer he corets, makes friends with the dog, plays a sly trick upon pussy, and ingratiates himself into the faror of the cook, from whom he expects some 
dainty morsel. Tis natural food is carrion, but he frequently kills labbits or chiekens, aud sometimes will attark young or sickly lambs. He is a voracions feeder, and will always be found rearly for anything from the table that is allowed him. The Raven may he confiner, but will take care of himselt if tumer loose, remaining alout the house just as the dog or the at will do, and always torning up at meal-time for his regular portion. The entting of the string of this bird's tongue, in order to facilitate the articulation of worts, is a needless performanee, and must be regarded as a foolish, arcient eustom.

Crow (Corells Americanus). This birel is better known in this comntry than the Raven, being fonnd ahumbantly over the whole of Eastern North America. Ilis length is not over a foot and a halt, his color being a deep black. If taken from the nest and realed hy hambl, the Crow is capalule of ready domestication. IIe does not learn to talk as well as the Raven, hut will perform many anmsing tricks. As a pilferer he will fairly dispute the falm with the other members of his family. His natural food eomsints of a gereat variety of substances, both animal and regetalile. On aceount of his fondness for spronting eorn, he is particularly detested by the farmers, who plan many a means 
for destroying him, but no bird knows better how to take care of himself than he. He is not, however, so harmful to agriculture as some suppose, as he consumes a great quantity of grubs, mice, insects, etc., which molest the growing crops. Generally the hahits of the Crow differ little from those of the Raven, and his treatment in the household may be similar to that given to the latter hird.

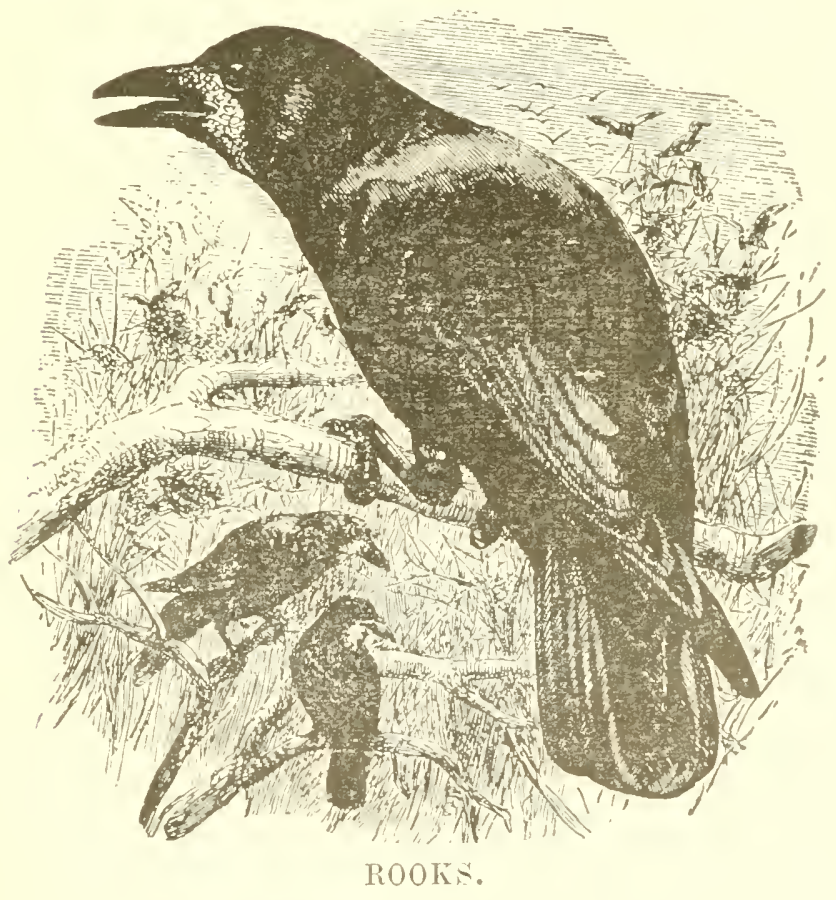

Rooks and JAckDaws alle the most common birds of this class throughout Europe...They are much smaller than the foregoing species, and possess. 
many traits to reeommend them as household pets. They are, however, seldom met with in this country, and any detailed description of thenr is unnecessary. Their treatment difters in no essential barticular from that of the Crow. When kept. confined, only the largest-sized cages obtainable are fit for these hirds. It is hetter to allow them the run of the premises, as they can take care of themselves and never seek to wo away. They will be sure to turn np punctually at meal-time.

Magpe. This hird is rather remotely connected with the foregoing varieties, and is found in most parts of the world. The American Magpie is a mative of Wentern North America, where he is found in great numbers, and hears a bad reputation for his sly, pilfering habits. ITe is a beantiful bird, with a long, graceful tail, whisking himself ahout with a janty erace. When domesticated he becomes almost a positive nuisance on account of his familiarity. Ile amuses by his buftoonery and delights with his apt remarks. As a pilferer he is withont a rival; many a shining trinket he delights to conceal, and many an article of value has been traced to his den. To he taught to speak, a Magpie should be taken from the nest and reared by hand. Words and short sentences may be easily taught. but the tones of the bird are usually too 
sharp and shrill to perfectly imitate the human voice. A great variety of food may be given the Magpie; scraps of meat or bread will be relished, and what he does not eat will be hidlen for a future meal. The Mocking-bird food may be fed him regularly as his principal article of diet. The bird does not require confinement, except oceasionally as a punishment for some bad trick, or as a means of restraining too much familiarity. He is subject to few diseases, and will live usually from fifteen to twenty years.

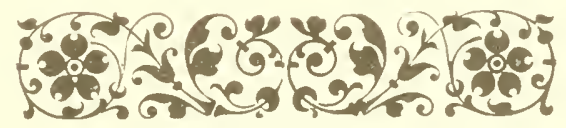




\section{('HAT'TER IX.}

\section{THE ditARY.}

HHE liking that somb persons latre for birds is fully satisfied when they possess one or two suredmens: others, howerer, find their greatest pleasme in ministering to the wants of many of the feathered minstrels. It one has the time and inclination to attend properly to the daily needs of an ariary collection lis eftorts will certainly be well repaicl. It will not do, however, to own a number of hirds and shirk the daily necessity of taking proper care of them.

All hirds are not equally suitahle for such a purpose. Some are of a quarrelsome disposition and therefore incligible; others are too greedy and would devour more than their share of the daily allowances. Small birls are usually to be preferred to large ones as a matter of course, but much depends upon the space allotted to the collection when the size of the birds to be admitted is under consideration. A very large collection of living birds would require nearly the entire time of a single person in caring for their wants, and such collections are seliom met with. If a well- 
situated conservatory an be utilized for the purpose, the effect will he most heantiful and striking. Strong smolight would be objectionable, hut such could be properly modified. Gorod ventilation wonkl be at all times a necessity, and ret dranghts of air should be constantly guarded against. Nothing would prove nore lisastrons to the birllife within than currents of coll air sureing through the room. Snall fir trees should be tastefully placed here and there throughout the suace, together with such other sturly plants as good judgment allows. Rustic perches may be next appropriately arranged so as to make the room as suggestive of outdoor life as possible; it will be better, howerer, to remore the bark from the perches, leaving only the plain, smooth wood surface, such remoral being necessary to prevent the accumulation of lice or parasites of any kind. Nesting places are to be provided for in sequestered nooks, and material for lining such furnished in abundance for the birds. Deer's harr is best for this purpose, but any soft, fibrous material will suffice. Cotton and wool are objectionable as the fibres are tough and long, on which account they frequently entangle the bird's feet, sometimes seriously, before the matter is discovered. If a fountain or a rumning rill of water can be placed in the interior of the aviary, it will prove highly bene- 
ficial as well as pleasing, as the water may he utilized for both bathing and drinking at the pleasure of the lirds. Plenty of fresh gravel and some lits of old plaster must be kept about the flool"; some tresh sol will also furnish much amusement to the occupants, who delight to rest upon it and for fun s sake tear it into shreds.

Foorl of a proper kind should he furnished in valretr; the kind to he deternined by the needs of the hipds as explained in the descriptive matter elsewhere. Some limels are of such a greedy disposition, likesome persons, that they would fill themselves to satioty, if aceoss to quantities of food were grven, thus doing thenselres a positive injury besides robbing their mates of their proper allowance. Such hipds shomld he excluched from the collection: the Bobolink is tashioner after this mannel, as is also the Rose-breasted Grosbeak. Tarions anveniencies for making the lite of the birls happy will suggest thenselves to one who is interested in his collection. Let no one owning such an aviary attempt to shirk the responsible duty of keeping everything neat and clean, else an endless amount of trouble may ensue. Parasites will torm to make both bird-life and man-life miserable: cleanliness and proper ventilation are effectual preventitives for such a condition.

If an aviary on such a large scale is not desira- 
ble, a much smaller one may be arranged by using a large cage, say from four to six feet in length and proportionately broad and high. This will accommodate, of conrse, a smaller number of birds, and the smallest-sized birds only wonld be admissible. In such a collection might be placed the English and American Goldfinches, Bullfinches, Linnets, Canaries, Nonpareils, Indigoes, Japanese Robins, Java Sparrows, African Love-birds, Australian Paroquets, and the interesting family of Finches and Nuns that are brought to this country in great variety from Africa and A ustralia. To a larger collection may be added such birds as the Virginia Cardinal, Scarlet Tanager, Brazilian Cardinal, Chaftinch, Lark, Sparrow, Thrush, ete. Many of the birds here named have been already described as cage-pets, while a few remain to be noticed in this connection.

Japanese Robin. This is certainly one of the most interesting birds ever subjected to domestication. He is beautiful in plumage, sprightly in manner, and a lively and engaging songster. His size is about that of a Canary; his eye is particularly large and brilliant. This bird is said to be quite common in the countries of the extreme East, and a favorite with the natives. The rapidity of his movements in a cage is most remarkable; no 
other bird darts with such lightning-like speed. He delights in somersaults and evolutions of all sorts and so sprightly are his motions that the eye can harlly follow his gliding form. He becomes very tame, readily learns tricks that can be taught to any other bird, and is ever ready to delight his mate with some new whistle or melody.

Insects and worms are the natural food of the Robin in his native state. When contined, the preparerl Mocking-bird seed is proper for him. Insects and meal-worms may be given ocuasionally, and some ripe fruit. A bath once a day should not be neglected, as this bird is fond of playing in water. He is one of the most suitable birds for the aviary, but may he given a cage to himself. This, on accomnt of his active movements, should be a conmodious one.

Jara sparrow. Although not a songster of any note, this Sparrow attracts much attention on account of his pretty and compact plumage. His length is about that of a Canary, his beak stont and delicately tinted; the general plumage is of a slate color, the cheeks being pure white, the throat and face a shining black. Tava is the home of the bird, where, it is said, he is as great a nuisance as the English Sparrow in America. The food of the Java Sparrow is rice, and great flocks molest 
the rice-fields of the eastern planter, notwithstanding all the "scare-sparrows" or other derices that can be thought of to keep him away. He is there

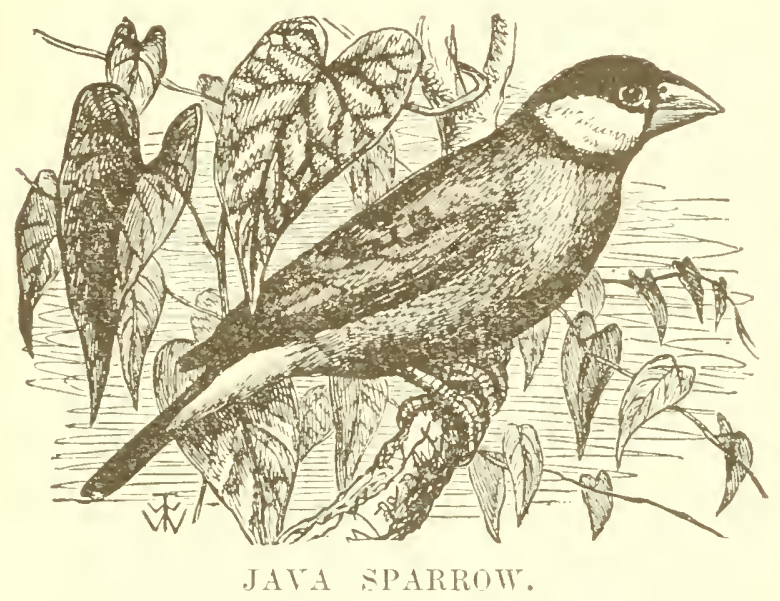

known as the Rice-bird. The bird's food in confinement is unhulled rice with a slight mixture of canary-seed. He may be separately confined if desired, but he is a handsome addition to the aviary.

Finches and Nuxs. No ariary collection is complete without at least a few specimens of these neat, diminutive birds. The countries of the Orient furnish them to the world's bird-markets. The number of varieties is rery great, and only the best known species can be mentioned in this connection. Considering the warm countries in which they are bred, these birds are reasonably 
harly, living some eight or ten years if properly acclimaterl, and being subject to few diseases. Some few are quite good songsters, lunt most of the birds are desirable on acount of the beanty of their plumage, diminutive size, and quaint habits. Two or three dozen are often contined in a single cage, in which they may frequently be seen all perched upon one stick and warbling their sweet ditties in regular succession. In size these birds vary from two to four and a halt inches in length; in a few instances an musually long tail increases the total length to some ten or twelve inches.

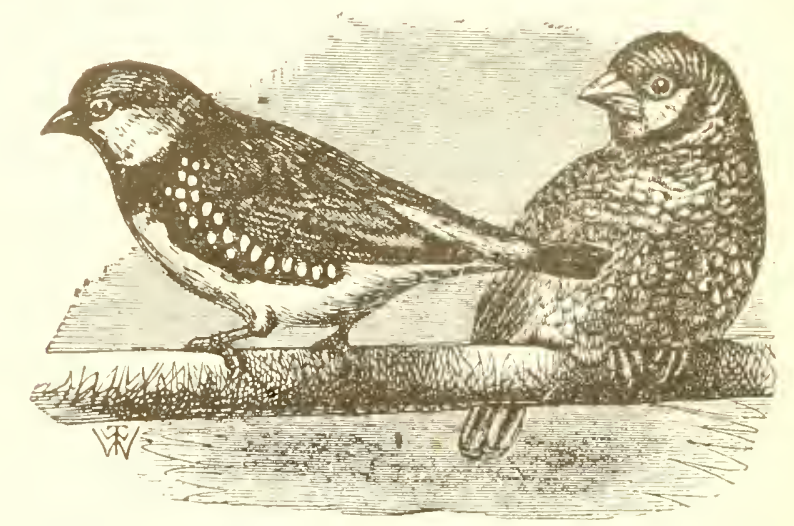

DIALONU SPARROW.

CUT-TILROAT FINCH.

The Paradise Whydal, is a bird of the latter class, its long, graceful tail making it a beautiful addition to any collection. It is in the breeding season that the tail grows to its greatest length, and the plumage of the bird assumes the richest hues. 
A showy bird for the aviary is the Diamond. Sparrom, the length of which is about three and a halt inches. He is imported from Australia, becomes readily acelimated, and is quite hardy.

The Cordon Blue Finch is a good songster, and a much admired birt for his beanty. He is a native of Africa. Brownish-gray is the color of the back, and a pale sky-blue that of the face, throat, chest and tail, the male differing from the female by having a crimson patch on each cheek. This bird is very fond of his mate, and gives utterance to distressful cries when separated from her. His sweetest songs are sung only for her: he delights to pour fortl melody after melody for her sole pleasure, while she. with reciprocating satisfaction, hearkens attentirely. If the bird happens upon some piece of wire, straw, or similar object, he will seize it in his beak, fly to his mate, and begin his most charming utterances.

The Common Warbill Finch is a pleasing aviary andition, and one of the best known of its class. The male and temale are alike in colors, fond of each other's society, and given to pluning each other's feathers with their tiny beaks. The male, in singing, spreads his feathers fan-shape, and with ecstatic zeal endeavors to win the approval of his "better-half." The pair will breed in confinement, and will rear their young without much difficulty. 
The St. Helena Warlill is larger than the preceding species, bnt while quite similar in color, his appearance is somewhat handsomer. The beak is coral-red, with a red line extending through the eyes. The body eolor is a delicate brown, a roseate hue being prominent orer the abdomen. He is a conspienous beanty among many of his kind, and a sociable bird at all times.

The Zebre Finch readily breeds in confinement. He is one of the smallest as well as one of the handsomest of his kind. The prevailing color of this hird is a delieate gray, marked by spots and bands of chestuut and black. His song is pleasing, but not so prolonged as that of some of his fellows.

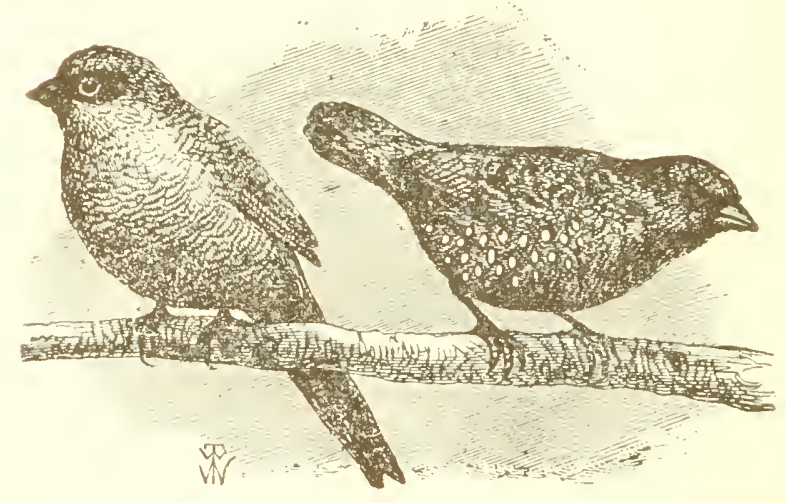

ST. HELEN.I WAXIILI.

AVAIATAT.

The demdarat is one of the smallest of his kind, and one of the most interesting and desirable in the aviary. The bird is imported from India, and large numbers find their way to this eountry yearly. 
The Magpic and the Cut-throat Finches, both from Africa, are pretty songsters, and quite quaint in their ways. The latter gets his name because of the peculiar red band across the throat. Both of these birds have a peculial trait of executing a song and dance at certain favorable moments, when the whole assemblage is quiet, and it occurs to one that a spirit moves him.

The Nuns are a class of birds very small and quite similar to the Finches. They are imported chiefly from Jalan, being known as the Japunese Nuns or Manalins. The Japanese are said to be expert bird-brecters, in consequence of which these small hirds display the marks of high breeding, just as the Canaries do that are bred in Germany. The fimmly of Nuns, like the Finches, emhrace many varieties, characterized by handsome colors and shadings. They form a very interesting class of birds, very desirable for the collector's aviary. All varieties will, under proper treatment, breed in confinement. They should have food and care quite similar to that given to a Canary, the Canary being itselt a Finch. The treatment in disease is also similar. The best food for the birds is a mixture of millet and canary-sect, two parts of the former to one of the latter. Lettuce and ripe apple should be given occasionally, and fresh water furnished for drinking and bathing. 


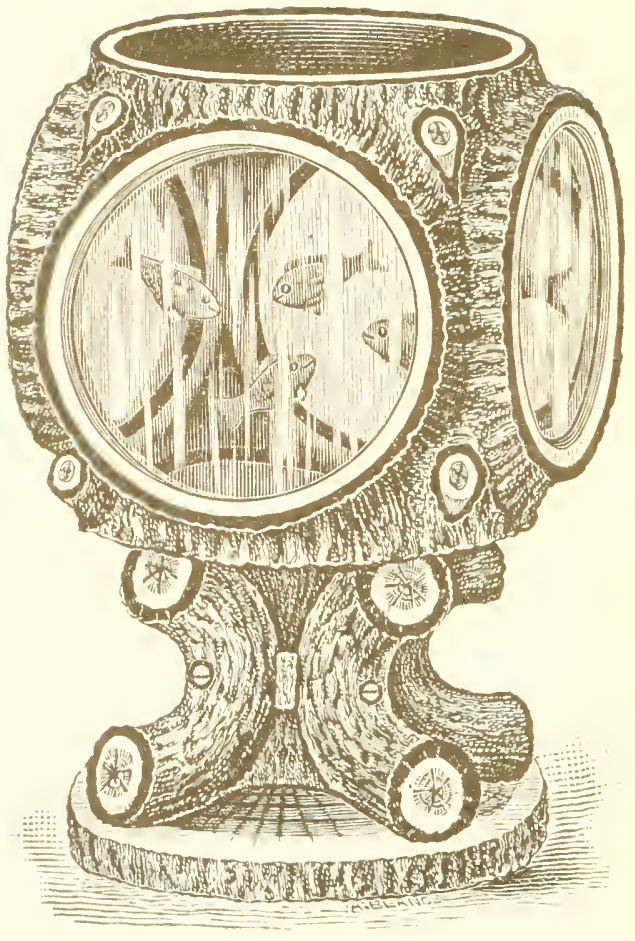

RUETIC AQLARILM. 


\section{THE AQUARIUM.}

\section{CHAPTER X.}

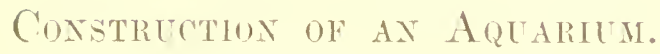

6 INCE home-life must constitute for many the greater liart of their earthly existence, it is natural and proper that all reasonable eftorts be manle to embellish the home with objects of interest and pleasure. Annong the many ornaments from which one may choose for this purpose, what can give rise to more real cujoyment than the aquarinn! How many hours can be passed in delightfully contemplating the actions of its finny inhabitants, husying themselves in the regulation of their household aftains so different in character from those of the terrestrial objects about us! It opens up to us a world of study that all the wouderful instruments of science cannot reveal or fathom, placing before on eyes the mysteries and the phenomena of the liquid world. Young and old can glory in its revelations; placed in the invalid's chamber it cannot fail of leing a source of continual interest and never-tailing delight. 
Constrictue I'RIAcIPLks. The aquarium scientifically constructed is of comparatively recent origin. There must exist in it those mutual relations between plant and animal life that Nature herself has established for their growtl and sustenance. Al] animals must inlale oxygen gas for the purification of the blood and the lieat of the body. Atmospheric ail contains this gas mixed with another called nitrogen, and respiration on the part of animals brings these elements into active relationship with the blood of the borly. In the laboratory of the lungs, the corpuscles of the blood sieze mpon the oxygen they desire and give luack a quantity of earbonic acid gats, the result of combustion that has taken place in the "apillaries of the hody. Now this latter gas is a poison to all animal olijects, whetler they exist in the air or in the water. Wherever it accummlates in considerable quantities it is certain to canse speedy annililation of life. By a wise regulation of Nature the very gas that is so lestructive to tlue existence of animal lite possesses tor all regutation life-giving properties. That which is griven forth as refinse ly the animal and of which it must not partake again upon penalty of destruction, is the rery food that is to feed and sustain the plant, and that which the plant throws ott as refinse is the precions oxygen which the 
animal so greedily devours. Thus has the Creator established a means of purification which operates at all times for the mutual support of the life of plant anc animal. Fish, as well as the other objects of the animal creation, must have a constant supply of pure air, and while it is trie that they need less of this as a rule than some other. animals, the element in which they exist must contain certain proportions of that gaseous fluid. Bearing in mind such fundamental principles of nature, an aquarium may be fitted out and stocked with its finny occupants so that the tronble of keeping it may he reduced to a minimum. The water of such an aquarium wonld never need changing, although the amount lost by evaporation would need to be occasionally replaced.

Fista-Globes. By the use of the ordinary fishglobes such an adjustment cannot be well secured. They are too small to permit the introduction of aquatic plants, consequently a frequent change of water is allsolutely necessary for the preservation of the fish. How often such a change will have to be made will depend mpon several circumstances-the purity and

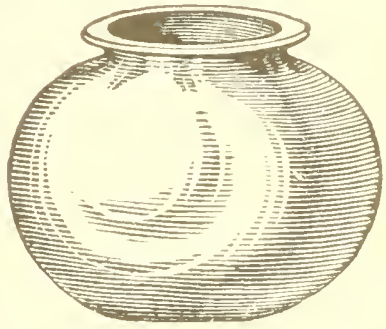
heat of the atmosphere, the quantity of the water, and the number of the fish inhabiting it. In a 
pure atmospliere of moderate temperature, two gallous of water will support three or four Golufish for several lays. Thenerer fish are ohserved coming to the top frequently for air, it is a sure indication that the water should be changed. The higher the temperature, the more impure the atmosphere, the langer the fish, and the greater their number, all will determine the length of

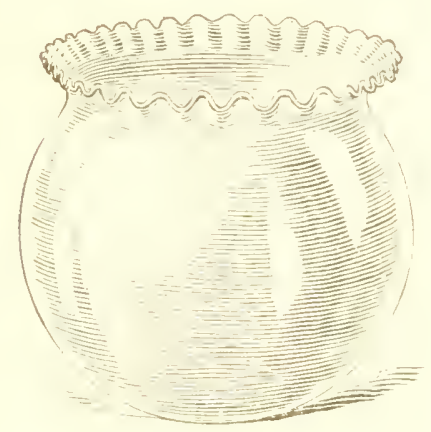

time that water may be retainerl. Many change the water in globes once a dily regularly, nsually choosing the evening for that jur'pose. The process in rely simple: Carry the globe by the rim firmly, holding the sime between the forefingers and thumbs; place the sprigerot of the hrolrant well down into the globe; let the water run slowly and overtiow for al mimute or two, then carefully replace the globe. A siphon may be usent to draw out the stale water, which is inmediately replaced ly fresh. A rul.ber tube an be employed for this purpose.

Fish glohes are sulject to a number of objections which cannot be nrged against the properly prepared tank. In the first place, they are very sulject to brakage, especially if their proportions are arlequate for a consilerable number of fish. 
One never knows at what moment some mulucky action may cause a globe and its contents to meet destruction upon the carpeted floor. Again, the spherical shape of a globe eauses a distorted riew of the fish as they swim majestically about in their aqueous element, thus defeating one of the most interesting features of the aquarinm-the proper inspection of the morements of the fish as they glide hither and thither.

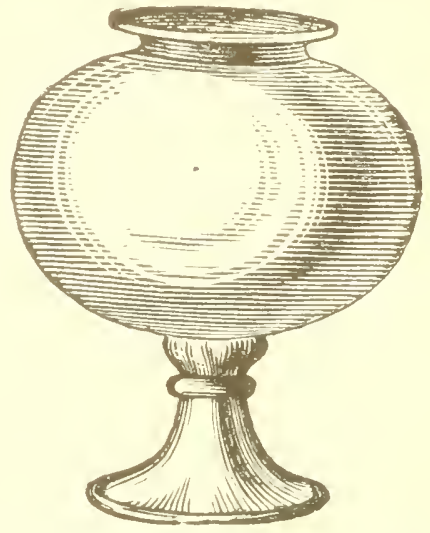
Globes, however, are attractive ornaments, and if one does not mind the slight trouble of changing the water frequently, and will exercise great are to prevent their demolition, they will serve very well.

Tanks. To any one who really desires to possess an aquarium, the tank is recommended as the only satisfactory receptacle for the water. Tanks of all sizes and shapes are to be found in well. equipped stores where fish are to be obtained. The best form is the rectangular, since it will be found not only the most elegant, but likewise the strongest and safest. It aftords the best opportunities for observing the curious habits of its finny 
occupants, and allows the most picturesque adjustment of arpuatic scenery.

Much ingenuity may be displayed in fitting out the aquarium, abundant opportunities being afforded to exhibit one's skill and good taste in this matter. Do not, in the first place, overstock the space with sundry embellishments. A few simple pieces of rock-work will amply suftice, if quietly and naturally placed. Remember that

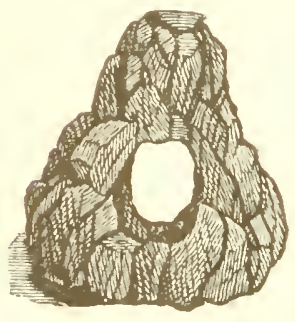
every piece of redundant scenery lessens the space arailable for animal and vegetable life. There can now be obtained in the stores many forms of beautiful grottoes and rocky representations that set oft" the tank to a good advantage. Beware of using sea-shells and coral in fresh water aquaria, since they are not onlyout of place, but the lime and other substances of which they are composed inpregnate the water to a considerable extent, much to the injury of the fish. Let your aim be to make your scenery as suggestive of fresh water life as possible. Castles do not exist at the bottoms of lakes or rivers, nor is coral found in such places. It will be found expedient to fasten all rock-work to its place, otherwise an unexpected jar might cause it to topple over, much to the detriment, possibly, of the finny pets, if not to the sides of 
the tank. A cement purposely prepared for this work can be obtained. A good aquarim cement may be made by mixing one part by measure of litharge, one part plaster of Paris, one part fine beach sand, and one-third part of fine powdered resin. Keep the mixture lry in a bottle, and when wanted for use make it into a putty by adding good, boiled linseed-oil. It will stand in either salt or fresh water. The character of all substances introluced into the aquarium should be closely questioned, inasmuch as the water might become impregnated from them with deleterious matter that would end the existence of all plant and animal life. After the work of cementing the rock-work has

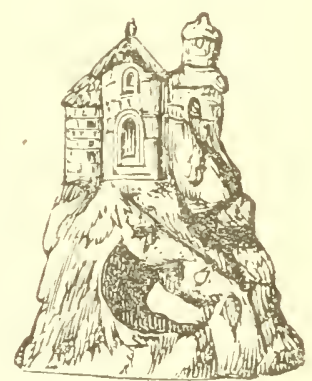
been satisfactorily completed, water may be introduced for a few days, to absorb the impurities that would come from the cement or rockwork. Scum will arise on the water, which should be replaced with fresh until it is found that the liquid remains pure. After a thorough soaking demonstrates that no more effuria is likely to arise, the bed of the aquarium may be placed and the plant-life introduced. Procure a quantity of clean, river sand, together with some pretty pebbles, and after washing these until they are thor- 
oughly freed from dirt, distribute them evenly ovel the bottom of the tank to a deptlo of nearly an inch.

Plants for an Aquarium. Plants appropriate for the fresh-water aquariun may be obtained in abundance from the ponds and brooks of our country. A stroll by any brookside, or a visit to any marshy spot, will reveal to eager eyes some of the choicest of aquatic plants. A small aquarium will not need a protusion of plants any more than it needs an over-strock of rocks. A few well-selected plants will suffice, and, incleed, will present a better appearance than would many. It will be found necessary to fix the roots of most aquatic plants, and this may be done in a variety of ways. A ball of wet clay may be made to inclose the roots, and this deposited in its proper place then corered suugly with sand or gravel. Or the plants may be rooted in saucers or other shallow dishes, that may be hidden from view by the sand in the bed of the tank. Many of the grottoes and other imitation rock-work to be bought in the stores for use in aquaria, have at their bases a number of excavations in which plants may be rooted. Some plants grow in the aquarium with wonderful rapidity, so that it will be found necessary to prune them frequently to prevent them monopolizing the whole 
space of the tank. Water-weed, which grows prolifically in many parts of the country, is one of this sort. If a piece be cut off' and thrown carelessly into a tank, it will soon fill the entire space it left undisturbed. It is of a bright green color, and particularly attractive. Water-cress is a wellknown fresh water plant that may be appropriately transferred to the aquarinn. There is a kind of crowfoot growing in water that may be obtained in the spring months. This may be given a home in the tank. Arrowhead is a common plant with white Howers with golden renters and leaves shaped like arrow points. Water millfoil and stalwort, common in ponds in many sections, make beautiful aquarium growers. The plants that grow rooted in watery beds, but expand their foliage above the surface, are not as clesirable as those whose leaves are nearly or wholly submerged. 'The reasons for this are obvions, if the precerling facts concerning the respiration of plants are borne in mind. In the former case the oxygen that the plant exhales is liherated in open air, while in the latter it is hound to permeate the water. Again, in the former ase the carhonic acid gas which the plant needs is taken from the air, and that which exists in the water remains unused, much to the detriment of the animal life of the aquarium.

Care should be taken to remove all docaring 
leaves and branches of fresh water plants, as the gases arising from deeay would pollute the water. Likewise, plants should not be permitted to grow without stint. Keep them pruned and within bounds. Too much oxygen, ats a profusion of plant-life would be sure to produce, would be as bad as too little. The purpose of the presence of plants is that they shall consume the impure gas that the fish exhale, and give out in turn the oxygen that the fish require, so that there may be a perfectly mutual balance between plant-life and animal-life.

Water for tue delarium. After the plants have been secured and arranged accorling to taste, the water may be put into the tank. Soft spring water is the best for this purpose, but river or clean eistern water will answer the purpose admirably. Water strongly impregnated with mineral substances, such as iron, sulphur, lime, ete., while they may or may not be good for the human frame, are not suitable for an aquarium, and should never be used. Such waters, when boiled in order to free them from such objectionable substances, are still unserviceable, as the gases of the water are driven off by the heat, and must be replaced before the liquid is capable ef sustaining either fish or plants. Atter placing the water in the tank, let your 
aquarium stand for a week or two, in order to give the plants a chance to begin growing and to get into a thrifty condition, before adding the fish. A comple of pond-snails may lie put in at once. They will act as scavengers, by consuming decaying vegetation and the confervae or greenish weed that discolors at times the surface of the glass. Such snails may be easily found by inspecting streams of shallow water or the recesses of ponds.

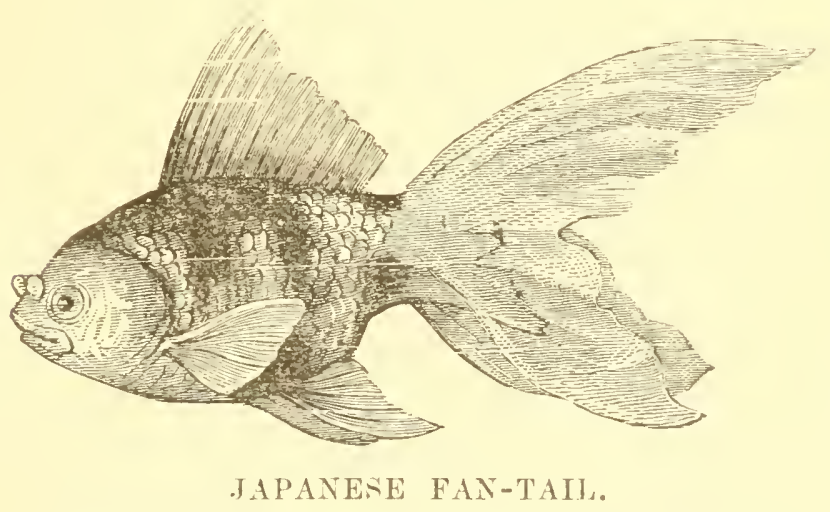

The Frsh. The selection of proper fish for a small aquarium would not be a difficult matter for many. Gold-fish are the universal favorites, and their varieties Silrer and Pearl. They are a beautiful species of carp, originally imported from Chinese waters, but are now very extensively bred. at home. These fish have, by long attention to breeding, been made to exhibit many varieties of shape and color. Some have plain, straight tails, 
these being the commonest sort and the cheapest. Some are known as Fan-tails, because of the threelobed and spreading eharacter of the tail, and others are called Gorgeons-tails, on account of the length and wary appearance of the caurlal appendage. A fish very much prized for its beauty is the Paralise fish. In color the Gold-fish differ among themselves ahnost as willely as they to in shape. Sone are pealy white marked with red blotehes, like Chinese hieroglyulies; others have black spots as well as red. Gold-tish are hardy, and with proper care will live for years with little attention.

Onr own fresh water streans will turnish many desirable secimens for the aquarium. The Mimnow is well known to every school-boy, and is so conmon that it can be pussessed with little trouble. 'This fisle is not only a pretty one, but bears the adritional reputation of being easily tamed. Ife can be taught to cone up and take food from the liand, and to lemonstrate a fondness for his henefilctor.

The Sticlilebucti and Gudgeon are diminutive fish found plentifully in some of our fresh-water strams. 'The former, however, is quarrelsome and hardly a fit companion for well-mannered fish.

There are many other varieties which may be obtained from tresh water streams at little expense. 
They will be found to be hardy, and to bear their confinement well. They should be taken by means of a net, and not by the hook, if the former means is possible. Care must be taken that fish are not introduced that will prey upon their fellows. Many do this, and had better be relegated to the shady sicle of nowhere for their mischievous ways.

A small turtle, a frog, or a diminutive eel, will add variety to the collection and will do no harm to the other inmates. If you have left your rockwork to project a little above the surface of the water, these specincus will often delight to crawl up out of the water and sun themselves upon the rocks.

It is necessary, at this point, to warn the enthusiast against placing too many fish in the same leceptacle. A given quantity of water will not support an unlimited number of inhabitants, so that if the proper proportion is overdone disaster will be sure to follow. Two fish not exceeding thrce inches in length may thrive in one gallon of water; if the fish are smaller, the sane quantity of water may accommodate more. Do not fill the tank completely full of water, as the fish might possibly jump out, and the turtles, lizards, frogs, etc., might take an unexpected leave of absence. It is best not to fill the tank more than four-fiftlis full of water, unless there is a screen cover to the aquarium. 
Feeding the Fish. Food is as necessary to fish as it is to other animals, but many persons are apt to over-feed their pets, or to give substances that are injurious. Pastry of all kinds, bread, crackers, etc., are wholly unfit for fish, and should never be given them. Such food substances are apt to elog the gills of the fish and thus choke them. A prepared food is sold by all dealers in aquaria which is well adapted for this purpose. This should be given, a little each morning, taking care not to furnish more than the fish will eat at one time, as that which remains is likely to pollute the water. Feed but little at a time, and when the fish seem to have enough, put your food aside and give nothing more until the next day. Some do not feed the fish but once or twice a week. By some fishbreeders, ants' eggs, such as have been recommended for birls, are regarled as the only proper food for fish in the aquarium. Three or four eggs may be allowed to each fish daily. These are relished by the fish, and snapleer up with avidity.

For turtles, eels, and hrook tish generally, worms are an excellent food. It is better to cut them into small pieces hefore feeding. Worms may be kept through winter hy placing a sufficient quantity of them in a small box, and placing the same where the frost will not reach it. Raw beef is a good substitute if worms cannot be had. It may 
be suspended so that the animals may nibble at it at pleasure. Dried beef may also be used, cut into fragments and fed just as it is deroured. Do not kill with kindness. It is easier to overdo the matter of feeding fish than to underdo it. See to it in particular that foor that is meaten is not left in the water to pollute it by decomposition.

Placing an Aquarium. A question often asked is where to place an aquariun to the best advantage, and in furnishing an answer the doctors somewhat disagree. All vegetable and animal life need sunshine, but too much of it will not he suitable for onr present purpose. An east window is sometimes recommended as the best aspect, for there a few hours sumshine wach day at a time when the air is mild and genial will amply suftice for the proper growth of plants and tish. A west window is good, however, and by some preferred as the best site. A south window is not so good, as the sunlight is there toostrong and heating. If it becomes necessary to use such an aspect, it is better to protect the exposed side of the ayuarium by means of a baize eloth. In too much sunlight plants give off a redundant quantity of oxygen, and a greenish muens will make its appearance upon the sides of the glass, obstructing the view of the observer as well as giving an irlea of nu- 
cleanliness. This is known as confervae, a vegetable growth which your snails will aid in destroying if it is not orer-abundant. A north window is not so suitable for the aquarium, as too little light is receivel from that source; but it will do if a bettel site is not accessible.

The temperature at which the water of an aquarinm is kept is an important factor in the health of the fish. This should not, if it is possible to aroid it, exceed sixty-five degrees, nor should it sink much below forty-five. A higher temperature than the above is weakening, and if excessive is very apt to canse the leath of the fish.

When once detemined mpon, the aspect should remain muchanged. At long intervals the aruarium will need cleaning. The fish maly be removed by ming shallow nets, and placed in a temporary receptacle. Nerel atch tish with the hand, as they areapt to be amshed enough to injure them by so loing. Ifter a thorongh renovating replace the water. The same water will do, or tresh spring water may he substituterl. The tank may then he returned to its antomalry platere and left nondistupher for another six monthis or a rear. Water lost by evapolation may he peplaced whenerer it is leened necossary. 


\section{PET QUADRUPEDS.}

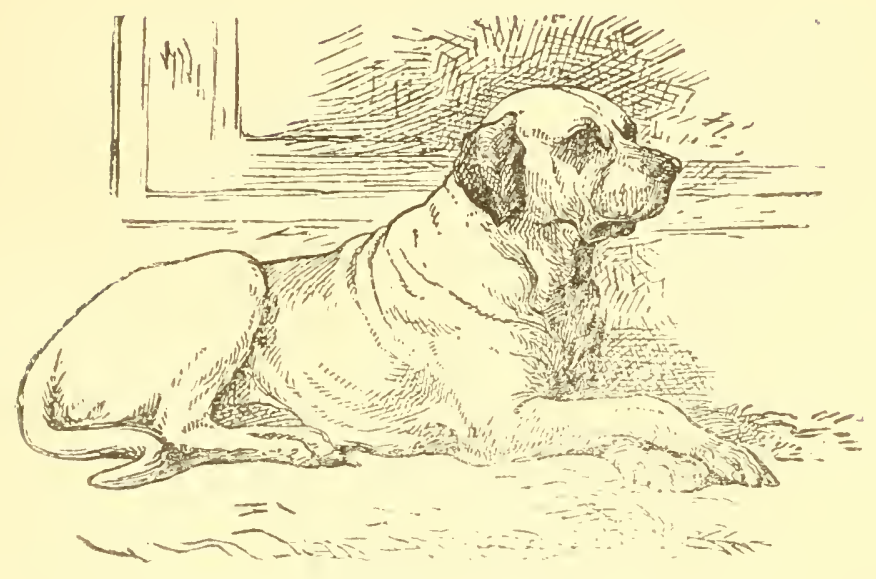

CIIATTER XI.

\section{I.-DoGs.}

66

N AN's nuselfish friend" is an epithet that the dog has not numorthily won. Although there are some persons who afticet to despise his qualities, the fact remains that no animal forms such attachments for man, and continues even to extremities so faithful to his trusts as does the log. It is said that when Sontlandis illustrious queen was led to the scaftold she was followed by her pet dog, which watched her execution, and refused afterward to leave her coftin until it was buried. Many a canine friend has 
watched faithfully at the bedsinle of a sick master, when human comforters have tumed unsympathetically away.

In intelligence what animal can excel the $\log$ ? He has been trained to perform the most remarkable tricks, and, indeed, has often excelled his instruction by the exercise of an ingenuity that seemed almost human. "If I had my chojce," once said a fancier, "between educating a dull boy and a smart dog, I would choose the latter." It would seem, indeed, from the instances that are on record of the remarkable sagacity of canines, that a limit hardly exists at which a dog”s capacities fail.

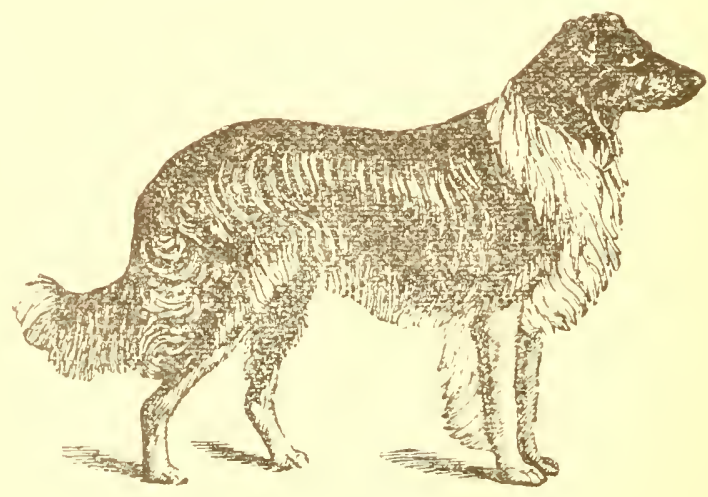

CUILIE.

Kennels and Bens. Every dog, whether large or small, should have certain quarters which he may regard as his own. If kept out of doors, as 
large dogs should certainly be, they should always be provided with a warm and dry kennel of comfortable proportions. A strong, hard-wood barrel, if first properly cleaned, will make a goorl kennel. Do not cut out the end, as is often done, but leaving both ends intact, cut out an opening in the side near one end, making the hole large enough to afford easy entrance and exit to the dog. If you should desire a better kennel, have your carpenter construct a commodious structure, and be sure to have the opening in the side near one end. The interior is thus freer from draughts, and will be warmer and dryer. Have the back constructed so that it may be opened when it becomes necessary to clean the kennel. The space designed for the dog's bed should be slightly elevaterl, with a slight slope. It should be plentifully provided with clean straw or fine shavings. At least once a week the dog's kennel should he scrubbed with hot water and soda, and the bedding renewed. Cleanliness in all matters pertaining to the dog will not only add to his comfort, but is an absolute necessity for his healthful existence. Fleas, ticks and other parasites are very apt to infest kemnels. It will be found easier to prevent their appearance than to destroy them when they hare once infested the dog's quarters. Once a day the quarters should be swept clean, and at least once a week a thorough 
scrubbing with hot water and soda should be given them. Some good disinfectant should then be used.

If a dog is allowed to remain in the house during the day, he should certainly be permitted to stay there through the night. The policy of turning out of doors for the night an animal, whether $\log$ or cat, is not only wrong, but eruel. When acenstomed to the warmth of the house during the day, he should not be compellerl to withstand the chill of the night, the time when shelter is the most needert. Let a warm, cozy place be selected for the honse-dog's quarters, and a rug or strip of carpet provided for his bed. He should be tameht to know that it is there he is expected to pass the night, and when the eommand is given, "Go to bed," he shomld he olliged to seck his quarter's and to femain there until morning. Some dogs, such as the delinate Toys, requile very cosy heds and covers, and such they will learn to use with great nicety. Lon't send yomr dog into the cellat to pass the night. and dont tix his quarters in a cold, draughty place, or behind a loos. Treat him loumanly or else give him away.

Fond axi Exercise. Usually dogs, and houselogs in particular, sufter from a lack of proper exercise, and the feceling of substances that would be 
proper nuder some conditions, but wholly nutit under others. The dog is a carnirorous animal, and flesh would uaturally constitute the major part of his diet. Deficient exercise. however, modities the nature of the diet; meat no longer should be the bulk of the animal's food, but should be replaced by vegetables of a light, digestible nature. Excessive exercise, on the other hand, such as is required of hunting logs at work in the field, walls for a generous feerling. Too much meat, either raw or cooked, can hardly be forl at such a time, but the same riet mnder conditions of rest of idleness would be wholly untit and injurious.

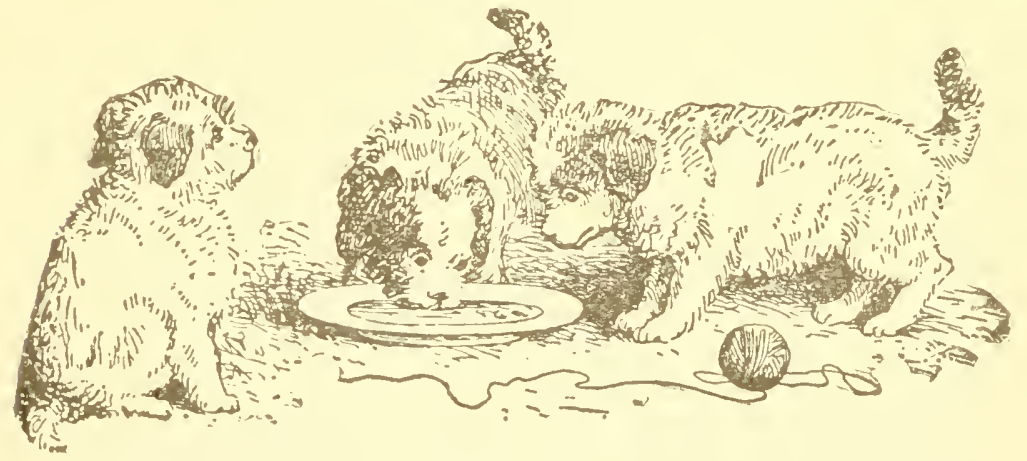

Puppies should he taug'at to lap milk when about three weeks old, as this relieves the mother of the great strain to furnish sustenance, particularly if the number of nursing puppies is large. Cow's milk for this purpose should be heated to scalding point, then slightly sweetened, and ferl when it has cooled lown to the temperature of. 
the dam's. If the puppy thrues on this dret, worms in the stomach are apt to thrive also, so that a diet of soun thickened with stale bread may be gradually substituted for the milk. Weaning may be accomplished at the age of six weeks, if the puppies are in good health. Four meals a day will amply suffice for them at this age, and these should consist chietly of the soup diet, together with well-boiled meat and vegetables. Puppies should not be permitted to gorge, as they are apt to do if left to eat all that they desire. At the age of six months three meals a day will be enough, and when a year old one light meal in the morning and a generous fexting in the evening will be found most conducive to health and strength. A large bone given to a dog to gnaw upon, is a good means of keeping his teeth clean and of furnishing bone particles, which are needed for the nourishment of the osseous system. Irregular supplies of food are injurious, and sweetmeats usually work mischief. Raw meat is apt to cause ferocity of temper, lesicles giving to the animal an offensive smell. The presence of cereal and regetable substances in the doges diet will be found, in most cases, to be preferable to an over-ahmulance of meat, this being true more particularly in regard to household pets getting rery deficient exercise. Dog-biscuits lave come into favor during the 
past few years, and are now extensively used by fanciers, whether as a matter of convenience or preference it would be difficult to tell. They are supposed to consist of such materials as are best adapted for feeding; most kinds are no doubt reliable, and may be recommended. There is no question in regard to their convenience, but that they are better than a diet prepared at home is very doubtful. In addition to such food supplies as have just been mentioned, fresh drinking water should be at all times accessible. This is very essential to a dog, as he requires drink frequently through the day.

The Batr. When properly kept, a house-dog should have a bath as often at least as once in two weeks, not only for the health of the animal, but for eradicating any offensive smell characteristic of canines, and for the prevention or destruction of parasites. The morning is the proper time for the dog's bath; luke-warm water should be used, together with a plentiful application of soap. Some of the excellent dog-soaps in the market should be employed rather than the common sorts, which contain strong alkali. Soaps contaning carbolic acid and other poisonous substances should be avoided, since they are injurious to both the skin and the hair. Atter bathing and rinsing with clear water, 
the hair should be rubbed dry and brushed, care being taken to prevent delicately nurtured dogs from taking coll. Small dogs should be placed in the tuh for their bath, large dogs beside it.

Diseases of Doas. Under proper conditions the dog is rarely attlicted by illness. Cleanliness in all natters pertaining to the animal's quarters, and regulapity in feeding wholesone food, will conduce largely to health. Some diseases result from contagion, but even these are luarlly to be feared if the general conditions of the dog are good. Infectious diseanes nsmally attack enaciated animals, hence the best safe-guard against them is a wellnourished system. In regard to remerlies to be given to a dog, it may be stated that a medium large dog, as a Setter or Collie, wall require as large a dose of medicine as a man, larger dogs more, and smaller dogs less in proportion to their size.

Distemper is one of the sererest tronbles to which a log is ever sulject. It msually aftlicts young dogs moler a year ohl, but old dogs are not exempt. A dog nay even he attacked hy distemper a second time. This illness is said to result from poison atloat in the bloor of the animal, and the symp toms are not unsinilar to typhus in man. The first appearance of the disease is in the watery discharges from the eyes and nostrils, by which means 
nature is seeking to throw off the poison aftlicting the hody. A firesh cold often exhibits the same symptoms, but is not accompanied by the rapid emaciation that is sure to follow if the trouble is distemper. A loss of appetite, sneezing, a cough, with frequent efforts to romit, shivering, and a feverish desire to drink, are symptoms nearly always present. The respiration becomes labored, fits sometimes occur, and the bowels show great irregularity. It is said on good authority that no specific is known for the absolute cure of distemper. The disease las its course to run, and good nursing will prove a most effectual aid to recovery. Remedies may and should be given that give temporary relief. Keep the patient in a warm, dry place, giving him an easy bed to rest upon. Give light, nourishing food, and place within ready access a pail of fresh water, from which the animal ean lap at his pleasure. If a dog refuses his customary food, he must be tempited with substantial dainties; and if these remain meaten, an egg may be beaten up in port wine and the animal torced to swallow it. Beef-tea and fresh milk are usually relished. If possible, consult a skilled reterinary in regard to medicines, but if that is impossible the remedies of the stores may be administered with good effect.

Fits, if not the result of distemper, are usually due to indigestion or the presence of worms in the 
stomach or intestines. This is a common ailment, and may be best remedied by seeking out and removing the cause. Keep the log quict, and give plain food at proper intervals. A close of cantoroil ma be given once or twice a week, and one to five grains of sulphate of zinc in a few grains of the extract of dandelion twice a day.

Mange is due to parasites that live and multiply in the skin. There are two distinct kinds of this disease, which are readily transmitted from one animal to another, and sometimes to man himself. There are other skin diseanes sometimes mistaken tor mange, which are not contagions, and require treatment ditterent firen that of the former tromble. Wash the garts well that are aftlicterl, and alply some good merempial or sulphur eintment. The animal may he given plenty of sulphur in his mills or food, ar Furlep's solution may les given in doses of firom one-halt to six drops, atcoroling to the weight of the due.

Home in a log are of difterent solts. Puppies are often attlicted with them, and death is sometimes due to their presence, even when they are wholly unexpected to be the soune of ailment. Round worms infest the stomach and small intestines. These cause much ipritation of the alimentary canal, and give rise to many disorders. A dog suffering with worms becomes emaciated without having ferer, is alternately afflicted with constipa- 
tion and diarrhara, and has at most times a ravenous appetite. The abdomen often appears bloated, while other parts of the borly are thin. Tapeworms and maw-worms, said by some anthorities to be much the same, are diffieult to erarlicate. Areca-nut is the commonest remedy for tape-worm; when freshly ground it is given in doses of two grains for every pound the dog weighs, the dose to be repeated in four days. Sintonine is given for round worms, from one-third to three grains being a dose. After the symptoms are abated give corlliver oil, and occasionally a mild dose of castor-oil, and at the same time a genepous liet.

\section{II.-CATs.}

The cat has been called the " perenet pet," and not without justice. P'ussy has always had hel friends and her foes; her ardent arlmipers and her extreme detestors. Faults she has, no doubt, but the lack of an aftectionate regard for the person who befriends her is not, as has been alleged, one of them. Thougin less demonstrative than the dog, the quiet rubbing of hel tur against one s person is no less indicative of supreme regard.

The cat is msually cleanly in her habits. She may be trained to act diacreetly in the house, and to observe her proper position at the fireside. Do not drive her out of the house to spend the night, if during the day she is permitter to remain in. 
A basket may be placed for her bed, and this she should be taught to occupy during the night. Feed your cat well; it is a mistaken notion that permits her to remain hungry with the idea that she will make a better mouser. Hunger will induce her to steal what is within reach rather than prompt her to seck for what is inaceessible. Two

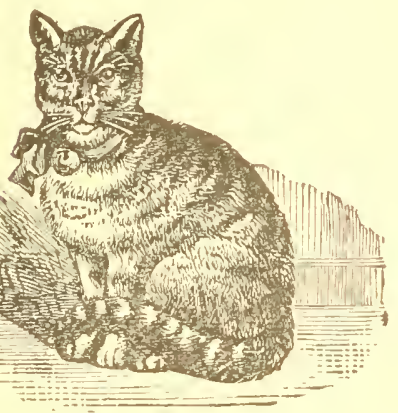
grood meals a day are enough for Pussy; let meat and milk be a part of her menu once each day. Oatmeal porridge and milk makes a good dish, and potatoes or other weliboiled vegetables are often relisherl. Fresh water should be always accessible. The indiscriminate feeding of a cat or any other pet is a mistake; regularity in feeding is more conducive to health. Begging for food on the part of any pet is a disagreeable habit that may be broken by resolutely refusing the petitions for ticlbits so prettily offered at the family meal. Kittens should be supplied with food more trequently than the grown eat. Three or four good meals a day are a necessity. Never take all of a cat's kittens from her at once; one should be left for her to raise. Never keep a number of kittens for which you are unable to supply good homes. Drowning kittens is a barbarous means of getting rid of sur- 
plus pets; chloroforming is, by all means, to be preferred. Place the kittens in a close ressel, together with a sponge saturated with chloroform, and death will soon ensue that is unconscious and painless. Cats that are infirm or diseased may be put to sleep by getting them to drink some syrup of chloral placed in their water. They may then be mercifully chloroformed to cleath.

"If a cat is really ill, he should be treated as a human patient is treated. kejet quiet and warm, and have medicine suited to his disolder. The most convenient and easily administered is the homeopathic. To insure the swallowing of roses having an unfamiliar or umpleasant taste, requires tact and some labor. The animal must be wrapled up closely, so that he cannot use his claws to protect himself from what he considers an outrage. his mouth opener, the medicine jourerl down, and his head held up till the dose is swallowed." -OLIVE Thone Mhter.

\section{III.-Rabits axd Guinea-pigs.}

\section{Among the most innocent} and engaging quadrupeds capable of domestication are the Rabbit and Guinea-pig. Both thrive well in confinement if strict cleanliness is at all times observed. These pets are very'

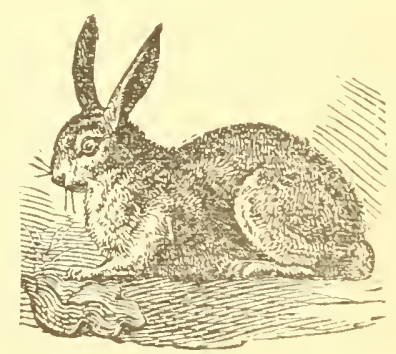
similar in habits and disposition, the latter, notwithstanding its name, being in no wise related to the beast that is said to leare a cloverfield so reluctantly. Feed plentifully fresh roots and vegetables, and keep in warm, dry hutches located in an onthouse. Guinea-pigs are born with their eyes 
open, well-coaterl, three to five at a birth. Rabbits are borm blind and lajeless, some two weeks elapsing hefore they sea the light. The young should be weaned at the age of six weeks, only one being taken fiom the dow at a time. Give them warm quarters plentifully provieled witle niee lay, and feerl soft food tor a time. Green food shonld be given sparingly to the young. Crushed oats and fresle roots, soakerl peas or beans, and boiled potatoes are all cxeellent. Rablits need but little to drink as they get sufticient liquids from the greon

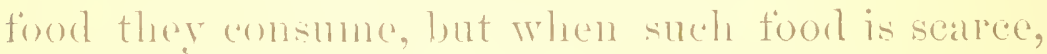
a little milk op milk and water may be furmished with aldrantage. Feerel twiee a lay. Be sure that thoir forol is firesh and that their quarters are

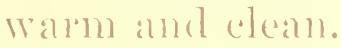

\section{T. SIITHRELS.}

Finuirlels become rely tame and are pretty, en-

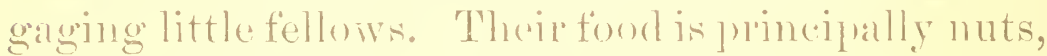
acorns and cereals. Breat and milk should be fed in addition oncea day. There should lue provided for them a regular squirrel cago consisting of three apartments, _a sleepring chamber, a feerling room, and a revolving wheel. T'he latter they will delight to turn at times, much to the delight of children, and of actults as well. Kíep the apartments scrupulously claun, as by this means only can insect pests be aroiderl. 


\section{INDEX.}

Acrirlents . . . . . . . . . . . . .

Americall Somgsters... ... T:

Actuarium ................. 1:!

" Fish for......... 1:39

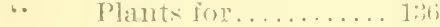

. Situating all...... 14:

$\therefore \quad$ Water tor........... J

Amowhearl ................

Asthma in birds............ :

Araclatat ................ 120

Ariary ................... 11 s

Birk-breeding in America..... "2)

Birk-lime................ 1:

Birrl-pexts ..............

Black-(*a)', European......... (i!)

Bolvolink................ 70

Inazilian Cardinal ........... . .

Preeding-cages . . . . . . . . . . . . 10

Brown Thrashel .............. हो;

Bulltinch................ il

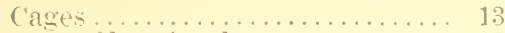

“ Cleaning bliks ......... 1;

Canary .................

"Breenting of .........

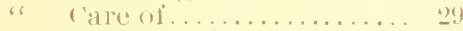

" Discases of ........... ty

" Fond for.............

.. Insects on ........... 30

$\therefore$ Tratining of.......... 1s

" Belgian............. "24

“ English............ 25

Cimary-serl ..............

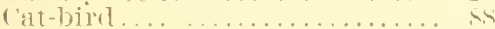

(at $\ldots \ldots \ldots \ldots \ldots \ldots \ldots \ldots \ldots \ldots \ldots \ldots$

(aven110 pepler........... \$1

Chathimeh.......... ... (i)

cockatoos.................. 111

Confervac.................. 14t

Convmlsions................ 58

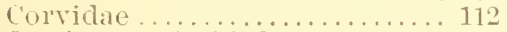

Costivenessin bilels .......... 51

Crampin in lird.............. 54

Crow $\ldots \ldots \ldots \ldots \ldots \ldots \ldots \ldots . \ldots \ldots$

Crowfont ............... 137

Diamond spartow . . . . . . . . 125

Diarrhrea iu birds........... 52

Diseases of birkl. ............. is

Distemper in dogs............ 152

Dog-liscuits.
Dis $\ldots \ldots \ldots \ldots \ldots$ PAr.E

$\therefore$ bincases of .......... 152

“Fu(s) ior .............. 14

" kemmelsamel lierls........ 1ti

Furg-Ealting birls.......... 4.5

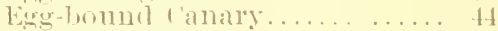

ligs and cracke jixture......

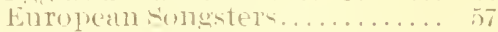

Finches, African . . . . . . . . . 12: Common Wax-bill.... 12.

Coprom blue ......... 1:5

('ilthlont. . . . . . . . 127

Magrife......... 127

st. Heleta .......... 12ti

. Zebra ............. 12ti

Fish, feediug of ........... 14:

Fish fol aplatism .......... 1:3!

Fish-mlubes. . .................

Foorl for hirds .............. 14

(iolrlen liol)in.............. 91

Goldfinch. Americail .........

Enmlish ........... 万人

(rolde fish ................ 1:29

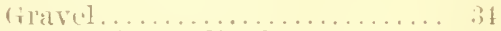

Groslueak, Carilinal .......... T,

Riose-fireasted ...... >i

Findgeon .................. 140

Guineat)

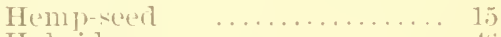

Hrblictx ............... ti

Indigro linnting............ it

Inflimmation of intestines.... 5 5

Jackilatrs... . . . . . . . . . . 11.)

Jal)antese Roljin . . . . . . . . . . . 121

Java sparrow . . . . . . . . . . . 12.2

Lameness in birds. . . . . . . . . . 54

Limnet, Red................ (t)

Lories...................... 111

Loss of voice................. 5.

Love-1)irds................. 109

Macaw, Iine and Jellow...... 110 scarlet............ 110

Magpie ................. 116

Manakius ................. 127

Mange in $\log s . . . \ldots . . . . . . . . .154$ 


\section{INDEX.}

P.tiE.

Mating-fever ................ 34

Mlaw.sed .................

Me:al.worms . . . . . . . .

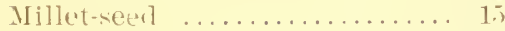

Mi11110سs............... 110

Morkinghird ... $\ldots . . . \quad 42$

Nockinghim foon ........... 17

Innlting period ...........

Vightingalle.............. (i.)

Nin]

Nums, Japhanese ............ 127

() riole, baltimore ........... 91 () rellared .... ...

Parlita .................... 16 Parallise Wligalah. . . . . . . . . . 1:4t Parmugets................ 117 Parrota ..............

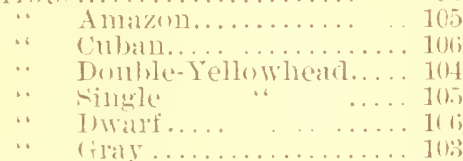

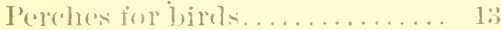
P(1)py-xerl . . . . . . . . . . . . . Psittacitale ........... 9.

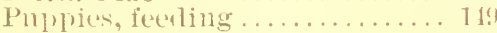

Rablits................. 157
PAGE.

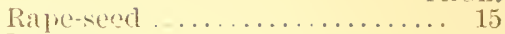

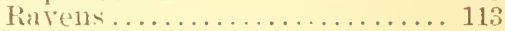

Rouks................ 115

frabrlet Tallaser............... \$9



Skylark ................

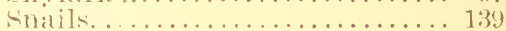

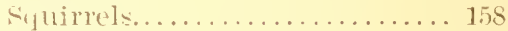

starling .............. . 70

Stalwort................ 137

Eticklebark................ 140

sturnidate ................. 95

simmllower-sted............. 16

Talking Мluor ............. 95

Tamming birlt................. 18

Tank fur anparimm . . . . . . . . 133

Tratpling bists............. 11

Tr(m)ial................ 93

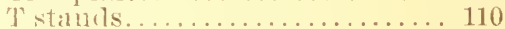

Turtles................... 141

$\mathrm{I}^{\top}$ mhrndled rice.............

Water for allonalinm .......... . 188

Water for bigrts.............. 31

Water (.ress................ 137

Water millfoil. . ........... . . 157

Water Weet. .............. 137

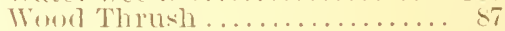

Worms in hogs............... 154

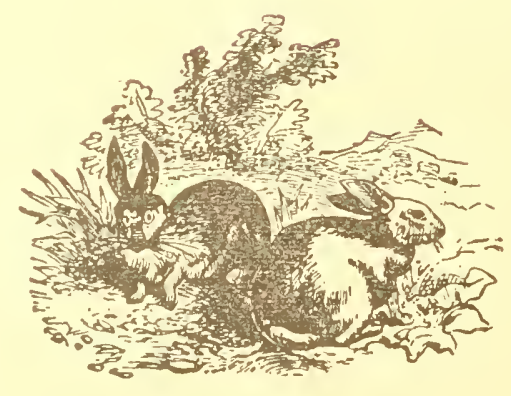


$x^{2}=1-2=$

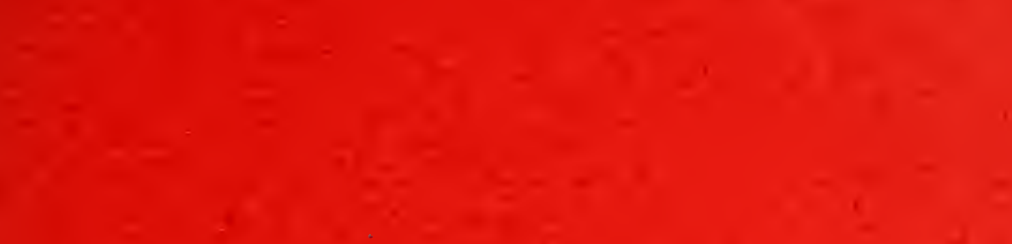

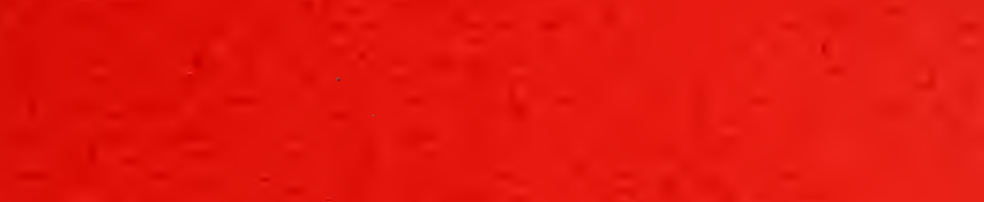

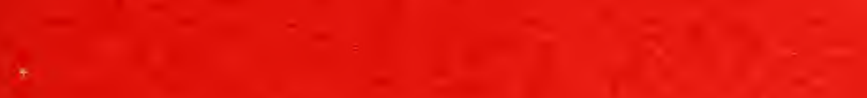

$8+3$

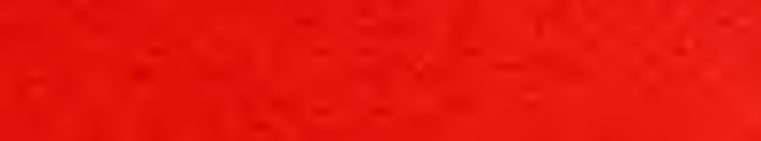

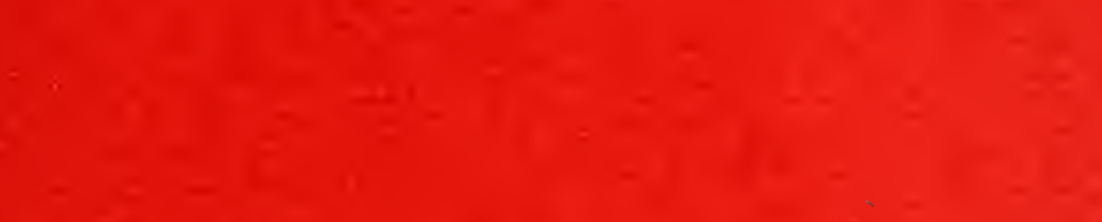

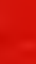

5.

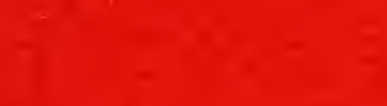

$\cos ^{2}=-19$

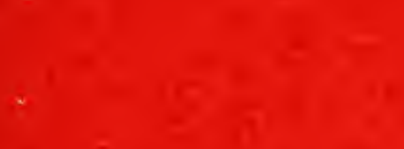

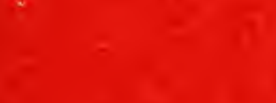

2.

it

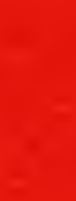
$-$ $x-$ $-$

3
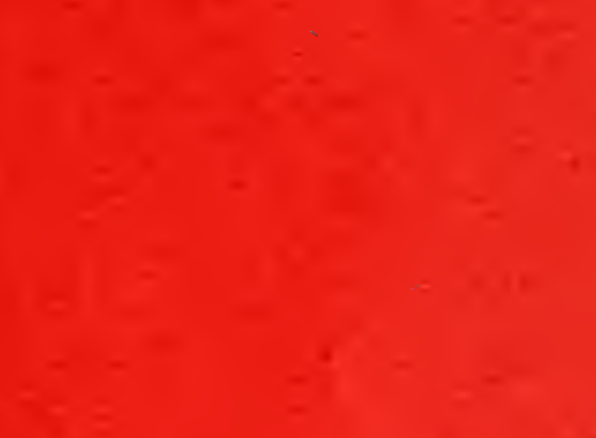

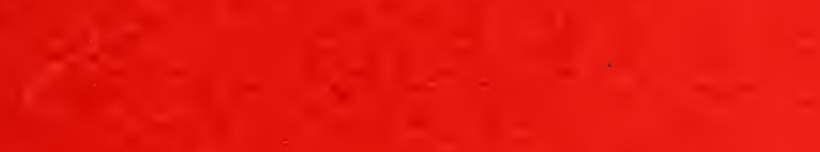
$x_{x=1} x^{-}$

$=7$

$$
x=
$$

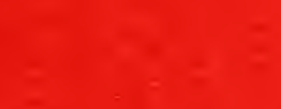

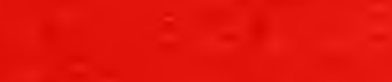

$$
\begin{aligned}
& -4=2= \\
& x+2=5
\end{aligned}
$$

1.

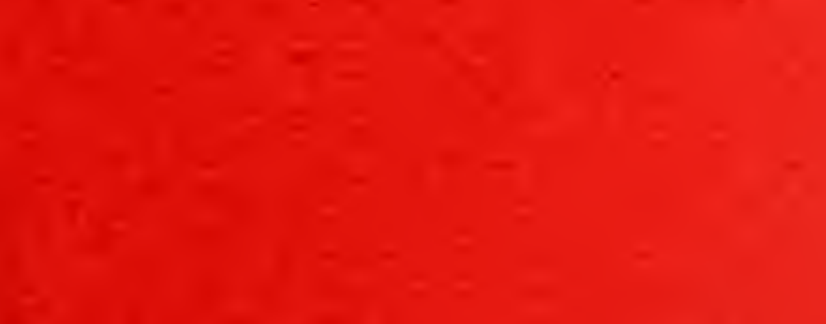

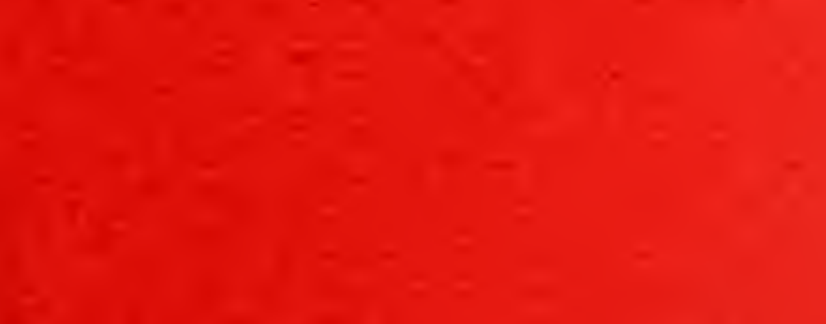

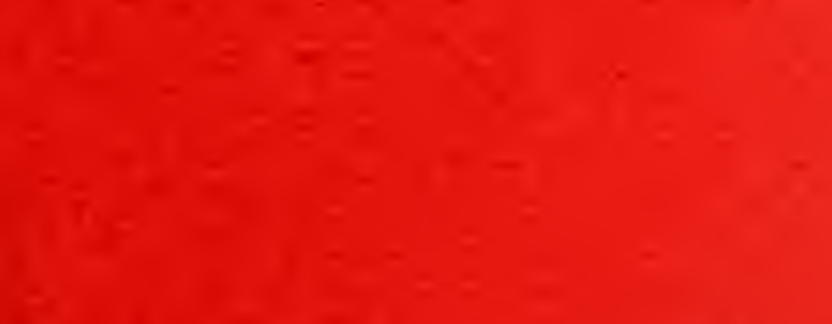

21

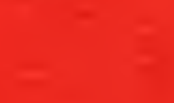


